\title{
ARTICLES
}

\section{PLAYING FAVORITES WITH SHAREHOLDERS}

\author{
STEPHEN J. CHOI* \& ERIC L. TALLEY**
}

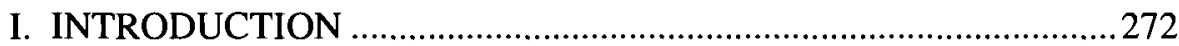

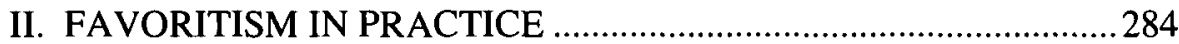

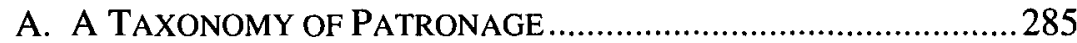

1. Distributions of Cash and Property ....................................285

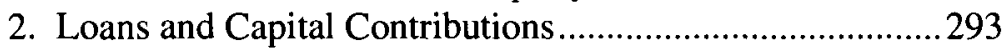

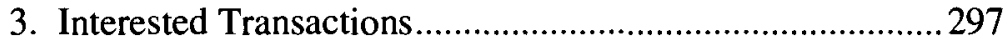

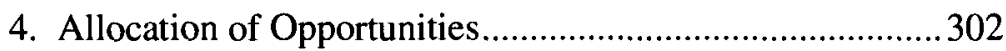

5. Allocation of Business Activities .........................................305

6. Disclosure of Nonpublic Information ..................................307

B. Practical Problems with Prohibition ..............................311

III. REASSESSING FAVORITISM ………………............................ 313

A. RECEIVED WISDOM ……………............................................. 314

B. A NEW THEORY OF PAYMENTS TO SHAREHOLDERS .................322

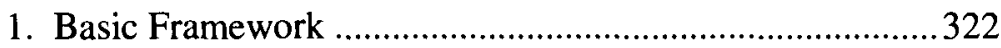

2. The Takeover Deterrent in the Absence of Favoritism .......326

* Professor of Law, University of California, Berkeley (Boalt Hall). Email: schoi@law.berkeley.edu.

** Professor of Law, University of Southem California Law School. Email: etalley@law.usc.edu. Thanks to Jennifer Arlen, Margaret Blair, Steve Fraidin, Jesse Fried, Andrew Guzman, Ehud Kamar, Ed Kitch, Gillian Lester, Paul Mahoney, Ed McCaffery, Kevin Murphy, Un Kyung Park, Mark Ramseyer, George Triantis, Michael Wachter, Mark Weinstein, John Yoo, Jan Zabojnik, and seminar participants at USC, Claremont College, Georgetown, Virginia, UC Berkeley, and the law firm of Fried, Frank, Harris, Shriver \& Jacobson for comments and suggestions. All errors are ours.

This Article is a companion piece to a more technical article, Stephen J. Choi \& Eric L. Talley, A Defense of Shareholder Favoritism, USC Center in Law, Economics and Organization Research Paper No. C01-11; and UC Berkeley Public Law Research Paper No. 62, available at http://papers.ssm.com/sol3/papers.cfm?abstract_id=276424. 
3. Allowing Favoritism to Shareholders ............................334

C. Caveats and Critical Assumptions................................. 344

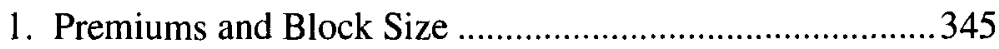

2. Credible Commitments ...............................................347

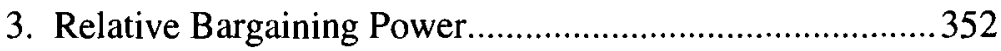

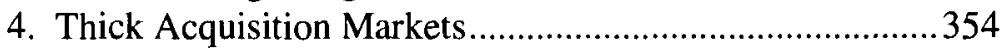

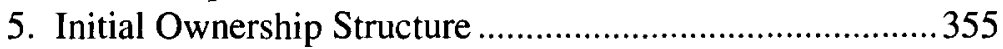

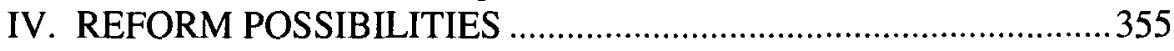

A. REFORMS TO THE REGULATORY SYSTEM...............................356

I. Selective Payments Reconsidered .................................. 357

2. Fiduciary Duties ...................................................... 360

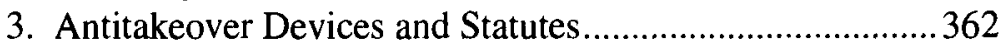

B. OTHER REFORM CONSIDERATIONS....................................... 365

1. Timing of the Managers' Commitment.............................365

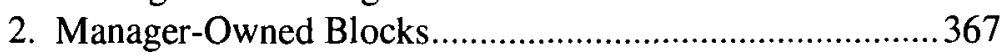

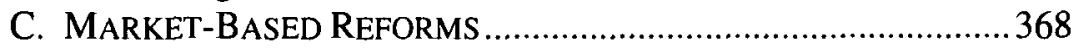

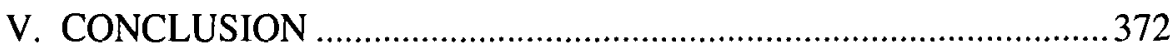

\section{INTRODUCTION}

One of the most vexing historical debates in corporate law concerns whether regulations or markets are better equipped to address managerial agency costs within public corporations.' Although corporate law scholars have traditionally favored immutable legal imperatives as an elixir for misaligned incentives, ${ }^{2}$ an increasing number of commentators place

1. This debatc is most salient when applied to public corporations for two reasons. First, because the shareholdings of public corporations are often widely dispersed, managers may enjoy greater leeway to operate the corporation to maximize their own welfare selfishly without fear of significant shareholder dissent. See Adolf A. Berle, JR. \& Gardiner C. MEANS, The Modern CORPORATION AND PRIVATS PROPERTY 6 (1933). Second, when shares are dispersed and publicly traded, it becomes possible for a single entity or unified group to purchase a control block of shares, threatening to wrest control from renegade managers. See, e.g., ROBERT CHARLES Clark, CoRPORATE LAW \$ 9.5.1, at 390-92 (1986); Eugene F. Fama, Agency Problems and the Theory of the Firm, $88 \mathrm{~J}$. POL. ECON. 288, 288-89 (1980); Eugene F. Fama \& Michael C. Jensen, Separation of Ownership and Control, 26 J.L. \& ECON. 301 (1983); Michael C. Jensen \& William H. Meckling, Theory of the Firm: Managerial Behavior, Agency Costs and Ownership Structure, 3 J. Fin. ECON. 305, 308-10; 337-38 (1976).

2. Jack Coffee, for example, has assessed the value of takeovers as a mechanism to align the incentives of managers and shareholders against other mechanisms, including "independent boards, shareholder voting, derivative litigation, or mandatory disclosure statutes." John C. Coffee, Jr., Regulating the Market for Corporate Control: A Critical Assessment of the Tender Offer's Role in Corporate Governance, 84 COLUM. L. REv. 1145, 1199 (1984). He contends that takeovers are "at best a partial remedy and cannot be seen as a substitute for other modes of accountability." Id. at 1200 . Coffee argues that a hostile takeover may not further social welfare for at least two reasons. First, Coffee notes that other mechanisms are more effective at aligning the interests of managers and 
greater faith in market mechanisms to accomplish the same task. ${ }^{3}$ While many such mechanisms operate simultaneously (including markets for output, ${ }^{4}$ labor, ${ }^{5}$ and capital $^{6}$ ), perhaps none has received more attention than the oft-celebrated "market for corporate control" as a means for

shareholders for all but "massive managerial failures". Id. at 1153. Second, Coffee contends that hostile takeovers may result in "serious diseconomies." Id. Hostile takeovers may occur not because of efficiency reasons but rather because the acquirer's management seeks to maximize the size of their firm. Additionally, the prospect of a hostile takeover may cause target managers to engage in more risky behavior to boost the value of their firm. Coffee also argues that an active hostile takeover market may reduce the security of managers in their jobs and thereby make the labor market less liquid as managers require a higher amount of salary to compensate for their reduced job security. See id. at 1158-60, 1221-50. See also Robert B. Rejch, The NeXt American Frontier 140-72 (1983) (advancing the argument that takeovers force managers to pay excessive attention to short-term gains at the expense of long-term planning); Leo Herzel, John R. Schmidt, \& Scott J. Davis, Why Corporate Directors Have a Right to Resist Tender Offers, 3 CORP. L. REV. 107 (1980) (contending that broad authority for the board of directors to stop hostile tender offers forces the bidder to negotiate with the board and thereby may lead to a higher premium for the target company's shareholders); Martin Lipton, Corporate Governance in the Age of Finance Corporatism, 136 U. PA. L. REv. 1, 20-25 (1987) (arguing that the takeovers have resulted in overly leveraged firms, harm to nonshareholder constituencies of a corporation, and an excessive focus on the part of managers on short-term profits); Louis Lowenstein, Pruning Deadwood in Hostile Takeovers: A Proposal for Legislation, 83 CoLUM. L. REV. 249, 268-309 (1983) (questioning the efficient market hypothesis and arguing that a hostile takeover based solely on a low stock price is unlikely to be correlated with poor management at the target firm).

3. John Pound, on the other hand, argues for a more "political" means of corporate oversight "in which active investors seek to change corporate policy by developing voting support from dispersed shareholders, rather than by simply purchasing voting power or control" including, for example, proxy contests and more informal consultations between management and investors. John Pound, The Rise of the Political Model of Corporate Govemance and Corporate Control, 68 N.Y.U. L. REV. 1003, 1004-10 (1993). Political means of oversight avoid the large transaction costs and disruption accompanying a change in control and are more politically sustainable compared with takeovers where active investors seek to change corporale policy by developing voting support from dispersed shareholders, rather than by simply purchasing voting power. Id. at 1009 .

4. Competition in the market for a corporation's output products reduces profits within the firm and thereby the rents available for managers to expropriate privately. Managers who shirk also run the risk of unemployment as competition drives their firms from the industry. See, e.g., Frank H. Easterbrook, Managers' Discretion and Investors' Welfare: Theories and Evidence, 9 DEL. J. CORP. L. 540,557 (1984) (contending that competition in a firm's market for output products forces the firm's managers to maximize firm value).

5. An active, competitive labor market gives managers an incentive to avoid developing a reputation for self-dealing, which would cause difficulties when they seek to obtain managerial positions in the future. See Armen A. Alchian, Corporate Management and Property Rights, in ECONOMIC POLICY AND the Regulation of Corporate Securities 337, 338-49 (Henry G. Manne ed., 1969). Cf. Shuichi Senbongi \& Joseph E. Harrington, Jr., Managerial Reputation and the Competitiveness of an Industry, 13 INT'L J. INDUS. ORG. 95 (1995) (predicting that managers produce more quantity than necessary to maximize profits in imperfectly competitive industries as a means of increasing their reputation in the managerial labor market).

6. The need on the part of some firms to return periodically to the capital market for new sources of funds may also constrain the ability of managers to appropriate private benefits of control. See Frank H. Easterbrook, Two Agency-Cost Explanations of Dividends, 74 AM. ECON. REV. 650 (1984). 
achieving deterrence. ${ }^{7}$ By providing a constant and credible risk of hostile acquisitions, the takeover market creates a powerful incentive for managers to constrain their own rapacity in the interests of self-preservation. ${ }^{8}$ Consequently, the argument goes, a principal normative aim of corporate law should be to ensure that the market for corporate control remains active, robust, and competitive.

It is therefore unsurprising that even champions of market incentives tend to cast lots with their proregulation counterparts in scrutinizing defensive practices that foreclose the possibility of a takeover. ${ }^{9}$ Consider,

7. See, e.g., Frank H. Easterbrook \& Daniel R. Fischel, Corporate Control Transactions, 91 YALE L.J. 698, 705 (1982) ("Corporate control transactions can reduce agency costs if better managers obtain control of the firm's assets or if they alter the incentive structure facing existing managers. Corporate takeovers, and subsequent changes in management, increase the wealth of investors."); Frank H. Easterbrook \& Daniel R. Fischel, The Proper Role of a Target's Management in Responding to a Tender Offer, 94 HARV. L. REv. 1161, 1169-74 (1981) [hereinafter Easterbrook \& Fischel, Proper Role] (arguing that hostile tender offers are one way for an outside investor to collectivize the interests of dispersed shareholders in monitoring management for agency problems); Ronald J. Gilson, $A$ Structural Approach to Corporations: The Case Against Defensive Tactics in Tender Offers, 33 STAN. L. REV. $819,841-45$ (1981) (arguing that takeovers are superior to mergers, asset sales, or proxy contests in displacing poorly performing managers); Henry G. Manne, Mergers and the Market for Corporate Control, 73 J. POL. ECON. 110, 113 (1965) (contending that "[olnly the takeover scheme provides some assurance of competitive efficiency among corporate managers and thereby affords strong protection to the interests of vast numbers of small, non-controlling shareholders"). See also Edgar v. MITE Corp., 457 U.S. 624, 643 (1981) (contending that "lt]he effects of [inhibiting takeovers] are substantial .... The reallocation of economic resources to their highest valued use, a process which can improve efficiency and competition, is hindered. The incentive the tender offer mechanism provides incumbent management to perform well so tbat stock prices remain high is reduced.").

8. Some takeover-market proponents have also criticizcd the effectiveness of more traditional means of aligning managers' incentives, such as fiduciary duties. For example, in an influential paper, Fischel and Bradley write:

Many analyses of corporate law assume that liability rules enforced by derivative suits play a fundamental role in aligning the interests of managers and investors. We have shown tbat this widespread assumption is not supportcd by either the theory of liability rules, the available empirical evidence, or the structure of corporate law.

Daniel R. Fischel \& Michael Bradley, The Role of Liability Rules and the Derivative Suit in Corporate Law: A Theoretical and Empirical Analysis, 71 CORNELL L. REv. 261, 292 (1986).

9. For a taxonomy of different antitakeover devices, see Clark, supra note 1, at 571-77 (1986). We should note that antitakeover devices need not always work to reduce shareholder welfare. Some such devices may enable managers to protect shareholders from coercive as well as inadequate tender offers. Defensive tactics may also help to foment a competitive auction for control, resulting in a higher price for target company shareholders. See Lucian A. Bebchuk, The Case for Facilitating Competing Tender Offers, 95 HARV. L. REv. 1028, 1046-56 (1982) (arguing that "acquirers may vary substantially in the amount of synergistic or managerial gains they can produce, and a rule of auctioneering increases tbe likelihood that the target will be acquired by the firm to which its assets are most valuable"). But see Frank H. Easterbrook \& Daniel R. Fischel, Auctions and Sunk Costs in Tender Offers, 35 STAN. L. REv. 1, 2 (1982) (arguing that auctions for corporate control "do not benefit investors as a group even though they may raise the price realized in particular cases. By raising the price, auctions reduce the number of acquisitions and thus the amount of monitoring."); Easterbrook \& Fischel, Proper Role, supra note 7, at 1175-77 (contending that managers should remain passive even where defensive tactics 
for example, the practice of paying "greenmail," i.e., causing the corporation to repurchase the stock held by an impending acquirer at a substantial market premium. ${ }^{10}$ With few exceptions, ${ }^{11}$ supporters of the takeover market view the possibility of greenmail (and other forms of standstill agreements) as an unwarranted impediment to market

may result in a higher bid price for the target firm). For an empirical study of the wealth effects of defensive tactics, see Robert Comment \& G. William Schwert, Poison or Placebo? Evidence on the Deterrence and Wealth Effects of Modern Antitakeover Measures, 39 J. FiN. ECON. 3, 6 (1995) (providing evidence that defensive tactics increase the target company's bargaining power and thereby the premium that target shareholders receive in a tender offer).

Notwithstanding the potential salubrious effects of defensive tactics, when an antitakeover device simply precludes the possibility of any takeover, commentators are more unanimous in their criticism:

If the company adopts a policy of intransigent resistance and succeeds in maintaining its independence, the shareholders lose whatever premium over market value the bidder offered or would have offered but for the resistance or the prospect of resistance. This lost premium reflects a foregone social gain from the superior employment of the firm's assets.

Easterbrook \& Fischel, Proper Role, supra note 7, at 1174-75.

Whether or not bidding contests are desirable, there are strong reasons for opposing defensive tactics, such as creation of antitrust obstacles, that obstruct the resisted offer. These tactics can be abused, as Easterbrook and Fischel observe, by a management seeking to perpetuate its control. Obstructing tactics also preclude shareholders from making their own decision whether to accept the offer. These concerns justify the prohibition of such tactics, even if Easterbrook's and Fischel's thesis on bidding contests is rejected.

Bebchuk, supra note 9, at 1029. See also Ronald J. Gilson, supra note 7, at 875.

10. A close cousin of greenmail, the standstill agreement, has also received attention. Through a standstill agreement, the target corporation pays money to a large block shareholder in return for the promise on the part of the block shareholder not to acquire additional shares. Standstill agreements frequently include a provision giving the block shareholder a seat on the company's board of directors. See Larry Y. Dann \& Harry DeAngelo, Standstill Agreements, Privately Negotiated Stock Repurchases, and the Market for Corporate Control, 11 J. FIN. ECON. 275, 279 (1983).

11. Jonathan Macey and Fred McChesney have attempted to provide one such exception, arguing that greenmail provides the target company's management the ability to cull out lower value bidders and thereby encourage higher value bidders into an auction for corporate control. See Jonathan R. Macey \& Fred S. McChesney, A Theoretical Analysis of Corporate Greenmail, 95 YALE L.J. 13 (1985). Under this account, greenmail provides compensation to an initial bidder in a takeover contest, inducing the bidder to invest in research to determine whether a company is a worthwhile takeover target. Id. at 28-32. Macey and McChesney also note the superiority of greenmail in relation to other defensive tactics from a shareholder welfare perspective. See id. at 29-30 (countering that "greenmail is unlike other defensive tactics, in that greenmail actually solves the free-rider problem that lowers the probability of an ultimate takeover"). Macey and McChesney also argue that standstill agreements serve to induce outside investors to reveal credibly their information to the target firm on the value of a potential merger. See id. at 34-37 (contending that "standstill agreements can also work as a bonding mechanism permitting the transfer of information"). See also Andrei Shleifer \& Robert W. Vishny, Greenmail, White Knights, and Shareholders' Interest, 17 RAND J. ECON. 293 (1986) (arguing that greenmail provides a signal to the market of a potentially profitable bidding opportunity and that greenmail also allows the target company to initiate a competitive auction by removing the initial bidder whose preexisting low-cost stake in the firm gives it an otherwise large advantage in the auction). But see Jeffrey N. Gordon \& Lewis A. Kornhauser, Takeover Defensive Tactics: A Comment on Two Models, 96 YALE L. J. 295, 315-17 (1986) (questioning whether management really has any informational advantage in determining the presence of other, higher value third party bids). 
discipline. $^{12}$ Greenmail, however, is but a focal point within a larger universe of takeover-retarding practices where managers bestow "favoritism" on certain block shareholders using corporate resources. Even outside of the context of an impending takeover, favoritism can (and does) exist in any number of forms: Managers may, for instance, sell discounted shares to select shareholders, thereby giving the shareholders preferential rights to the corporation's profits. They might alternatively seek to divert corporate opportunities and other favorable business prospects toward favored shareholders. Management may also seek to procure block shareholders' quiescence more directly, through express payments of cash or property in exchange for a portion of the block of shares. But notwithstanding its form, the various types of favoritism share a common feature: They all have the design (and frequently the effect) of co-opting the most plausible acquirers of the firm-block shareholders-converting them from market monitors into conspiratorial confederates of management. As such, the argument goes, shareholder favoritism retards the disciplining threat of a takeover, and is therefore likely to reduce aggregate firm value.

Critics of shareholder favoritism go further still, arguing that patronage not only reduces the effectiveness of monitoring, but in addition it permits managers to appropriate for themselves even greater levels of firm value, all to the detriment of shareholders as a group (and potentially that of other corporate stakeholders). Hence, conventional wisdom has largely held fast to its view that the law should proscribe (or at least discourage) the practice of favoritism toward block shareholders. ${ }^{13}$ The political durability of this position may also help explain the existing array of prohibitions against favoritism, ranging from bans on non-pro rata

12. See Ronald J. Gilson, Drafting an Effective Greenmail Prohibition, 88 ColuM. L. REv. 329 , 330 (1988) ("From the perspective of the protakeover forces, greenmail is just another, albeit more blatant, technique by which target management entrenches itself at the expense of target shareholders."). See also David Cowan Bayne, S.J., Traffic in Corporate Control-Greenmail: The Intrinsic Illegitimacy, 72 U. DET. MERCY L. REV. 511, 513 (1995) (contending that "[g]reenmail is nothing other than a recondite species of the broader genus Corporate Bribery, and as such is intrinsically illegitimate"); Note, Greenmail: Targeted Stock Repurchases and the ManagementEntrenchment Hypothesis, 98 HARV. L. REV. 1045, 1048-49 (1985) (relating the argument that managers may use greenmail payments to entrench themselves in control).

13. See infra Part II (discussing the legal prohibitions against the various forms of shareholder favoritism). On the other hand, certain forms of favoritism may also generate ancillary benefits to the firm. When a firm hires a shareholder as an employee, the shareholder may represent the best potential hire despite the danger that the firm is using the employment as a pretext to shift resources to a particular shareholder. Similarly, shareholders with good information on the company may offer the lowest cost source of additional capital for firms. Although these possible virtues are not central to our analysis, we briefly revisit them in Part II. 
shareholder dividends, to fiduciary duties of loyalty imposed on dominant shareholders, to federal tax policies and securities laws that work to inhibit various types of shareholder favoritism. ${ }^{14}$

In this Article, we question whether the general case for prohibiting favoritism is as strong as conventional wisdom suggests. Our analysis contains both practical and theoretical components. From a pragmatic perspective, we argue that the multi-dimensional nature of shareholder favoritism creates an immense regulatory obstacle for courts and legislatures. Indeed, while some acts of patronage are relatively simple to verify (such as outright cash payments to block shareholders), prohibiting such acts would be unlikely to eradicate the overall practice of bestowing favoritism. Rather, managers intent on playing favorites would simply relocate their activities, choosing less verifiable actions (such as the in-kind allocation of business opportunities). While regulators might attempt to compensate through ad hoc prohibitions on those less direct forms of patronage, so doing would not only add significant administrative costs, but it might simply induce managers to readjust their strategies yet again. All the while, in an effort to outwit prospective proscriptions, managers would adopt increasingly indirect and inefficient contrivances for transferring value, compounding burgeoning administrative costs with additional deadweight losses that often attend in-kind transfers. This inefficient dynamic may ultimately render the regulatory game unworthy of the candle.

Nevertheless, even if prohibiting favoritism at zero cost were a practical regulatory option, we contend that the theoretical case for doing so is far from clear; rather, we shall argue, explicitly permitting favoritism might better serve the interests of shareholders as a group ex ante, even if it might appear undesirable from an ex post perspective. Our theoretical argument stems from a simple observation: Takeovers require substantial investment on the part of an outside acquirer to execute successfully. Nearly all acquirers, for example, must pay a hefty premium above the current secondary market price to execute a hostile acquisition successfully. ${ }^{15}$ Consequently, a number of potential acquirers may remain

14. Most recently, the Securities and Exchange Commission ("SEC") promulgated regulations limiting the ability of corporations to favor particular shareholders, among others, with sclective disclosures of nonpublic material information. See Selective Disclosure and Insider Trading, Exchange Act Release. No. 34-43154, 73 SEC Docket 3 (Aug. 15, 2000) [hereinafter Promulgating Release]..

15. See Bernard S. Black, Bidder Overpayment in Takeovers, 41 STAN. L. REv. 597, 598-601 (1989) (stating that the takeover premiums averaged 50\% in the 1980s); Reinier Kraakman, Taking Discounts Seriously: The Implications of "Discounted" Share Prices As an Acquisition Motive, 88 
docile in the face of outright waste or self-dealing by managers, fearing that the payoff from a takeover does not justify its significant cost. And herein lies the rub-for a legal regime that permitted favoritism would provide investors with an enhanced incentive to assemble a significant but noncontrolling block of shares in the first place. Indeed, assembling such a "toehold" block would now confer two valuable benefits on its owner: first, it would give the block shareholder more credibility in threatening to engage in an outright acquisition (since the cost of the premium for assembling the block will subsequently be viewed as sunk); ${ }^{16}$ and second, it would afford the block shareholder an opportunity to lay claim to a share of the manager's private control benefits, threatening (credibly) a takeover if the manager refuses to render patronage. Furthermore, this second option does not even require that the investor ever build a control stake in the firm, a cost savings that proves to be important when (as is often the case) the premium required for assembling a block of shares increases with the size of a block. ${ }^{17}$

This enhanced attraction for forming a toehold, however, is but half the story. Anticipating the incentives of prospective toehold investors, corporate management must choose between two responses. One choice is simply to accommodate whatever block shareholders emerge, securing their quiescence through subsequent patronage and favoritism. ${ }^{18}$ While such a strategy might insulate the management somewhat from a takeover (and even increase the amount of private benefits that safely may be

Colum. L. REv. 891, 892 (1988) (noting that takeover premiums "now average over 50\% of prebid share prices"). See also Michael C. Jensen, Corporate Control and the Politics of Finance, J. APPLIED CORP. FIN. 13-15 (1991) (estimating that shareholders of target companies received approximately $\$ 650$ billion in premiums between 1976-90). Potential acquirers may also need to expend resources investigating a potential takeover target.

16. This first benefit, of course, would be present even if side payments were not possible.

17. Indeed, investors tend to pay a significantly larger per share premium as the size of the block they are purchasing increases. See infra Part lll.

18. Note that Macey and McChesney question the rationality of using greenmail to deter a hostile takeover when managers act opportunistically. Macey \& McChesney, supra note 11, at 41. "The greenmail game ... is one that any number can play. If management pays greenmail once in order to protect its jobs, it must be prepared to pay it again and again." Id. Other forms of shareholder favoritism, nevertheless, do not result in the repurchase of all of the favored shareholder's shares. For example, allowing the favored shareholder to exploit a corporate opportunity provides the shareholder a benefit without reducing the shareholder's ownership percentage in the firm. Once co-opted, the presence of a management-friendly block of shares then will raise the cost to other potential acquirers. The acquirer at the very least must assemble a control block larger than the preexisting pro-management block. As this Article discusses below, the presence of the preexisting block may also raise the cost to the acquirer of purchasing shares from among the remaining dispersed shareholders. See infra Part lll. 
appropriated from the firm ${ }^{19}$ ), it also requires sharing any private benefits of control with others. On the other hand, management could choose an alternative response of deterrence, so constraining its own ability to reap private benefits as to render the formation of any block unprofitable. We argue that under many plausible circumstances, managers would prefer deterrence to accommodation, opting (much like Beëlzebub ${ }^{20}$ ) to consume all of a small pie than a meager portion of a large one. In so doing, managers would voluntarily commit themselves to appropriating even less firm value than they would in a world where favoritism was effectively prohibited (and outside investors had to make a binary choice between inaction and outright acquisition). Furthermore, in conventional market settings where multiple outside blocks could potentially form (each demanding patronage from managers) this incentive to deter entry by block shareholders grows even stronger. As such, playing favorites with block shareholders may, ironically, be in all shareholders' interests.

The implications of our argument hold particular salience for those who would champion the market for corporate control as a remedy for managerial incentive problems. Indeed, our analysis suggests that a prohibition on favoritism-far from ensuring competition in the market for corporate control-may instead be an unintended incubator of managerial mischief. Consequently, we conclude that efficiency-minded courts and policymakers would do well to consider abrogating such prohibitions (at least in certain situations ${ }^{21}$ ). Doing so would force managers to reckon with the possibility that outside investors could form blocks solely to extract patronage, thereby inducing greater managerial discipline. This inducement, moreover, exploits managers' own expertise and knowledge in designing effective corporate governance devices to achieve deterrence. And, because the threat of block shareholder entry is ongoing and

19. As our model below demonstrates, even this proposition is questionable. Indeed, if management significantly increases the amount it expropriates from the firm, it might inadvertently make it into such a strong takeover target that it is impossible to deter the outside investor, even with patronage. See infra Part III.

20. In Milton's PARADISE LOST, Beëlzebub rationalized his exile into Hell in a manner similar to our hypothetical manager (albeit with graver consequences), stating:

Here at least

We shall be free; the Almighty hath not built

Here for his envy, will not drive us hehce:

Here we may reign secure, and in my choice

To reign is worth ambition; though in Hell:

Better to reign in Hell than serve in Heaven.

John Milton, Paradise Lost I:258-63 (Christopher Ricks ed., Penguin English Poets 2000) (1667).

21. See infra Part IV (detailing the contexts in which a permissive judicial posture is likely to be optimal). 
persistent, the incentive to engage in self-restraint would similarly be ongoing, long after the initial sale of securities to the public.

Significantly, because the benefits from allowing selective payments to shareholders derive from the ex ante incentive effects that are placed on managers, our argument extends even to (and indeed, particularly to) situations where the corporation is not an active target. ${ }^{22}$ Consequently, our argument provides a more general defense of shareholder favoritism based not on those instances where it occurs, but rather on those in which it does not.

Even for advocates of regulatory discipline over markets, however, our analysis may prove useful, in that it spotlights a significant danger of piecemeal prohibitions against shareholder favoritism. For pragmatic purposes, regulators are initially most likely to scrutinize the most overt forms of favoritism, such as outright cash payments to select shareholders. Indeed, these acts are the easiest for regulators to detect, to evaluate, and ultimately to punish. The problem with a piecemeal approach, however, is that managers may respond by simply masquerading their acts of patronage, embedding them within a different, otherwise value-enhancing type of transaction (such as supply contracts). Furthermore, once such an adjustment occurs, it may be quickly perceived by policymakers to constitute, on the whole, little more than veiled patronage-thereby justifying a categorical extension of regulatory scrutiny. This serial process can lead to a regulatory structure that is dangerously over-broad and ultimately self-defeating, inducing the true regulatory targets to substitute into another, more opaque and yet-unregulated sphere, while leaving more legitimate actors caught in the regulatory crossfire. Moreover, such complex contrivances can themselves introduce costs and inefficiencies that would not be present if devices of overt favoritism were allowed. Hence, even if one were convinced that shareholder favoritism is undesirable, ${ }^{23}$ it is far from evident that attempting to prohibit it with conventional regulatory machinery is a realistic (or prudent) policy choice.

Finally, our analysis exposes an important lesson for corporate scholars of all stripes who wish to assess the effects of shareholder

22. A different possible argument exists in support of managerial actions that reduce the threat of a takeover. Andrei Shleifer and Lawrence Summers contend that entrepreneurs may wish to implement antitakeover devices to protect the interests of managers in the firm-specific human capital they develop within the corporation. Andrei Shleifer \& Lawrence H. Summers, Breach of Trust in Hostile Takeovers, in CORPORATE TAKEOVERS 33, 42 (Alan J. Auerbach ed., 1988). Such protection, in turn, induces managers to invest in their firm-specific human capital. Id.

23. As noted above, we question the validity of even this logical predicate. 
favoritism as an empirical matter. Indeed, under our approach, it is the threat of having to share benefits that induces managers to exercise restraint, deterring the emergence of a block shareholder in the first instance. This deterrence benefit would simply not be apparent if researchers limited their empirical inquiries only to those cases where a block shareholder emerges and receives preferential treatment-in such instances a side payment need not make others better off. ${ }^{24}$ Our principal argument, however, is that the "off-equilibrium" benefits of deterrence (corresponding to those bribes which are never actually paid) may well swamp the costs detected in observed incidents of patronage. Thus, in order to conduct a more balanced and coherent analysis of such practices, legal scholars would do well to accord the dogs who didn't bark as much attention as those who did. ${ }^{25}$

Four caveats to our analysis deserve explicit mention before proceeding. First, our principal focus in this Article is the impact of shareholder favoritism on the threat of a possible takeover to align the incentives of managers with shareholders. There are, of course, countless other mechanisms that provide incentives in a parallel fashion that do not work through a block of shares (including executive compensation schemes, fiduciary duties, and so forth). Although we will touch briefly on many of these alternative devices, they are ultimately somewhat tangential to our enterprise. To be sure, responsible policymakers ultimately must evaluate an entire "portfolio" of incentive devices, of which markets for corporate control are only a part. But to the extent that such markets can be made to operate more effectively, they also can occupy a more prominent space within this regulatory portfolio. ${ }^{26}$

A second (and related) caveat concerns our assumption that managers are in a position to manipulate their firms' governance structures in order to appropriate value inefficiently. One might justifiably wonder, then, why organizational structures preventing them from doing so are not in place

24. But see supra note 11 (citing arguments that selective payments even in situations where they actually are made may increase overall corporate welfare).

25. For example, in their rebuke of Macey and McChesney's pro-greenmail arguments, Jeffrey Gordon and Lewis Kornhauser focus only on greenmail transactions that actually occur, arguing that the predominance of shareholder value-decreasing greenmail transactions over value-inereased greenmail transactions argues possibly for a complete ban of greenmail. Gordon \& Kornhauser, supra note 11, at 320. Our analysis, however, points out that in assessing greenmail among other forms of shareholder favoritism, commentators must focus also on the incentive effect placed on managers even where the payment is never made.

26. Indeed, all we must argue is that the reforms we advocate do not systematically undercut the ability of firms to utilize these other incentive devices as well. 
from the very beginning. Indeed, a well-known argument in corporate finance maintains that entrepreneurs have strong ex ante incentives to select the best corporate governance structure possible in order to maximize the price investors will pay for shares at an initial public offering. ${ }^{27}$ Thus, if managerial value diversion were inefficient, this reasoning asserts, the initial charter would prohibit it. While this argument is well taken, we find it to be of limited usefulness in a world of uncertainty. Indeed, the needs of most corporations vary over time, and most entrepreneurs lack the ability to predict with precision the firm's prospective needs. As such, it is virtually impossible to design complete governance structures that come close to maximizing firm value far into the future without also allowing for some managerial flexibility over governance ${ }^{28}$ Of course, this flexibility may also allow managers to exploit governance "gaps" by self-dealing. But at the same time, it is precisely in such circumstances where the market for corporate control becomes an important deterrent. As noted above, our analysis offers insights about how such a market can be made to operate more effectively, providing durable and continuous benefits well after a firm's initial public offering.

Third, it is important to underscore that our deterrence arguments focus on how permitting patronage affects firms whose shares are already widely dispersed. While this class of corporations is an important one from a corporate governance perspective, ${ }^{29}$ not all corporations have such widely-held ownership structures. ${ }^{30}$ For such firms, it is simply not possible to "deter" investors from forming an influential block-for one already exists. There, introducing a permissive regulatory regime may offer few benefits for nonblock shareholders, and may even come at the cost of inducing managers to co-opt existing block shareholders, who might otherwise be good monitors.

27. See, e.g., Jensen \& Meckling, supra note 1, at 305-07.

28. For example, in order to maximize shareholder value, a firm's entrepreneurs might have contemplated requiring that a certain fraction of its board consist of outside directors. The value of particular outside directors, however, will depend on their individual expertise and reputation for independence. Without good knowledge of the available pool of outside directors down the road, entrepreneurs would have difficulty determining the optimal mix of inside to outside directors. See Jeffrey N. Gordon, The Mandatory Structure of Corporate Law, 89 CoLUM. L. REV. 1549, 1573 (1989) (arguing that "[o]pportunistic amendment is possible because the corporate contract is inevitably incomplete. The parties cannot specify terms to cover even plausible contingencies ....").

29. See supra note 1 and accompanying text.

30. Many firms outside the United States and the United Kingdom, in fact, are characterized by a controlling block shareholder comprised of either a controlling family or the state. See, e.g., Rafael La Porta, Florencio Lopez-de-Silanes, \& Andrei Shleifer, Corporate Ownership Around the World, $54 \mathrm{~J}$. FIN. 471, 471 (1999). Our analysis therefore applies primarily to U.S. and U.K. corporations. 
And fourth, although we believe our arguments to be relatively general in nature, they depend crucially on a key assumption pertaining to managerial commitment. Explicitly, we assume that even if a manager's choice of precisely how much firm value to divert ex post is hard to detect, the manager must possess the corporate governance tools ex ante to constrain credibly subsequent personal diversions of value at some maximal level, and in a manner that is at least partially observable to outsiders. Indeed, it is precisely this act of commitment that enables shareholder favoritism to provoke the deterrent effect that we envision. In the absence of such tools, a manager's mere assertion of self-abnegation would be little more than cheap talk, incapable of deterring the formation of blocks. ${ }^{31}$ Notwithstanding the centrality of this assumption, however, we maintain that numerous actions falling within the domain of managerial power have exactly the effect we envision, including, inter alia, incurring highly monitored bank debt, executing long-term contracts, installing outside directors, and engaging in reputational bonding. ${ }^{32}$

Our analysis proceeds as follows. Part II provides the pragmatic portion of our argument, presuming (provisionally) that shareholder favoritism is undesirable and questioning whether effective regulation is practically feasible. This section offers a taxonomy of methods through which a corporation may favor its shareholders selectively and describes the regulatory system that governs them. We argue that the patchwork nature of this legal landscape is both inevitable and hazardous, raising serious doubts about whether effective regulation in this area is attainable. Part III then turns to the conceptual portion of our thesis, reversing our inquiry by presuming (provisionally) that effective regulation is feasible and questioning whether the goal of eliminating favoritism is itself justified. Here, we formally develop the argument that shareholder favoritism may, ironically improve overall corporate welfare. To do so, we employ a simple ${ }^{33}$ example drawn from game theory that analyzes how managers might constrain their abilities to take private benefits within the

31. Put another way, the manager's representation lacks credibility. Absent constant monitoring, once the pressure on managers is relieved, managers will simply appropriate as much value as possible. Of course, in a repeat relationship, managers may attempt to develop a reputation for maximizing corporate value above their own narrow self-interest. For a discussion of reputation among other devices for committing managers to limiting their private benefits of control, see infra Part III.C.2.

32. We explore these various devices and others. See infra Part III. We also discuss two other (less pivotal) assumptions that underlie our analysis: the increasing marginal cost of purchasing a block of shares and the allocation of bargaining power between the block shareholder and the manager. See infra Part III.

33. As noted above, while we pursue a simple example for reasons of tractability, our analysis extends to a more general environment. See Choi \& Talley, supra note **. 
shadow of a legal rule that alternatively prohibits and then permits favoritism. Using this example, we demonstrate how, if patronage were allowed, managers would prefer to deter the entry of block shareholders who expect patronage, and in so doing would commit to even less value diversion than they would in situations where favoritism is prohibited. Part IV discusses various reform implications from this insight. Because numerous means of favoring shareholders are possible, we argue that lawmakers should consider the interaction of these different payment schemes with one another. In particular, while courts and policymakers have moved to regulate the most easily observable forms of opportunistic payments more stringently, our analysis suggests that a better course of action (at least in certain circumstances) may be to permit more direct and observable forms of shareholder favoritism while regulating the more indirect forms. Part $\mathrm{V}$ concludes, discussing possible extensions of our analysis.

\section{FAVORITISM IN PRACTICE}

In order to conduct a meaningful assessment of shareholder favoritism, it is first important to be clear about how and when it is observed in practice. This Part, therefore, provides a description of various methods by which managers favor shareholders selectively and discusses the challenges that courts and legislatures have had in regulating them. Although ostensibly distinct, all of the methods noted below share at least two mutual characteristics. First, each provides an institutional mechanism for allocating to a favored shareholder some benefit, property, or legal claim whose value exceeds (in a pro rata sense) what other shareholders receive. Second, the methods below historically operate as instrumental alternatives for one another. In other words, the introduction of a prohibition against one method of selective payment can shift managerial behavior toward some alternative (and as yet unregulated) method. This cat-and-mouse game is reflected in a pattern of piecemeal regulation in which courts and legislators struggle to keep pace with an ever-shifting system of shareholder patronage. Thus, conscientious regulators must assess the desirability of regulating each selective payment method not only individually, but also in light of the likely substitution effects that would occur after regulation. ${ }^{34}$

34. Regulators, of course, could respond with an attempt to block all forms of selective payments. Such a broad regulatory prohibition, however, is not without cost. Different forms of selective payments may generate varying benefits to overall corporate welfare. Prohibiting all interested transactions with shareholders, for example, may rob the firm of an important source of 
For clarity of exposition, we shall employ throughout the remainder of this Article a hypothetical designed to illuminate many of the central issues at play. Consider Acme Corporation, a nationally prominent manufacturer of ten-gallon cowboy hats. Acme has 10 million shares of common stock outstanding, trading initially on NASDAQ at a secondary market price of $\$ 100$ per share, thereby giving Acme a total market capitalization of $\$ 1$ billion. Assume that this initial $\$ 100$ per share price reflects the true fundamental value, in present discounted value, of Acme's future cash flow (that is, if managed selflessly). Unless otherwise specified, we presume Acme to have many thousands of dispersed, well-diversified shareholders, each of whom holds a negligible percentage of Acme's shares. Acme's management team acts as a cohesive group, owns zero common shares in Acme, and individually receive a fixed wage. ${ }^{35}$ In addition, we consider one other possible player, Merit Investments, a privately owned mutual fund. Like other shareholders, Merit initially owns a negligible stake in Acme, but it has sufficient liquidity to amass as much Acme stock as it desires. By purchasing a sufficiently large block, Merit might be in a position to demand patronage from Açme's management team, threatening to consummate a takeover (displacing current management) if its demands are not satisfied.

\section{A. A TAXONOMY OF PATRONAGE}

Ignoring any legal prohibitions, Acme management has numerous mechanisms at its disposal to confer benefits on Merit. Although it is beyond our ken to canvass every one of them, six warrant explicit enumeration: (1) direct distributions of cash and property; (2) loans and capital contributions; (3) interested transactions between a firm and its shareholders; (4) the allocation of corporate opportunities; (5) the allocation of business activities; and (6) the selective disclosure of nonpublic information. We address each in turn, briefly analyzing their current legal status as well.

\section{Distributions of Cash and Property}

Outright transfer payments are perhaps the most obvious means to confer benefits on shareholders. Most directly, Acme may simply

\footnotetext{
capital and expertise. Moreover, as the next Part discusses, social welfare may benefit from even the opportunistic use of payments to select shareholders.

35. In order to concentrate on the takcover market as a disciplining device, we suppress (for now) the role that incentive compensation (such as options or stock compensation) might play in providing managerial incentives.
} 
distribute cash drawn from the corporation's treasury to Merit (and potentially other block shareholders); Acme could also transfer title to some of its assets or entitlements directly to Merit, possibly as a part of sales transaction at a price far below market value.

Somewhat less directly, Acme might also be able to transfer cash to Merit through the selective repurchase of Acme's shares. Share repurchases may occur in any number of ways, including negotiated oneon-one transactions, open market repurchases, or formal repurchase tender offers on behalf of the corporation. ${ }^{36}$ Note, however, that if they are done at prevailing market prices, share repurchases do not systematically favor the tendering shareholders over others. Indeed, suppose that Merit Investments has accumulated a large block of shares (say I million), and Acme now seeks to repurchase some of them. If the purchase price were set at $\$ 100$ per share-the prevailing secondary market price-Merit would not experience an appreciable gain from the repurchase. ${ }^{37}$ Only if the purchase price exceeded \$I00 per share does Merit Investments gain at the expense of the nonselling shareholders. ${ }^{38}$ Referred to as greenmail within the takeover context, ${ }^{39}$ favorably priced share repurchases from select shareholders can occur at any time (even in the absence of an imminent acquisition). ${ }^{40}$

More subtly still, Acme may be able to bestow favor on Merit by purchasing other shareholders' stock at a discount. Of course, such a transaction would require Acme to convince other shareholders to sell below intrinsic value, but in certain circumstances this might be

36. For a discussion of the different types of share repurchases, see Jesse M. Fried, Insider Signaling and Insider Trading with Repurchase Tender Offers, 67 U. CHI. L. REV. 421, 427-34 (2000).

37. Some gains, nevertheless, are possible. A large block shareholder may not have the ability to sell a significant fraction of its shares into the secondary market at the prevailing secondary market price. Once the market learns of the large block shareholder's planned sale, for example, the secondary market price may drop. The drop could occur either because the market takes the planned sale as a signal that the block shareholder believes the secondary market price is too high or because of the pressure a large influx of new shares into the market places on the secondary market price. The block shareholder could, of course, attempt to disguise its sales or negotiate a sale to one party seeking to accumulate a large number of shares.

38. Suppose that Merit sells 1 million shares back to Acme at a price of $\$ 200$ per share. After the repurchase, Acme will have a total value of $\$ 800$ million (down from its initial $\$ 1$ billion) and Acme will have 9 million shares outstanding. Each share will then be worth only eighty-eight dollars.

39. See Bayne, supra note 12, at 514-15 (defining greenmail).

40. After Ross Perot resigned from the board of General Motors in 1986, for example, GM repurchased all of Perot's shares in GM for $\$ 700$ million. GM Stockholders Irked by Buy-Out of Perot Warn Against 'Greenmail', ARIZ. REPUBLIC, Jan. 29, 1987, at C2. 
accomplished. ${ }^{41}$ For example, suppose that Acme management has just learned some nonpublic information about its future prospects (such as signing Garth Brooks to a cowboy hat endorsement deal) that would increase its fair market value to $\$ 1.2$ billion, resulting in a per share value of $\$ 120$. Acme might seek to repurchase 5 million shares from non-Merit shareholders at the prevailing market price of $\$ 100$ per share. After the repurchase, Acme will be left with $\$ 700$ million and 5 million outstanding shares, giving a per share value of $\$ 140$. If Merit does not tender any of its shares, Acme's purchase from others will leave Merit with gains of twenty dollars per share. ${ }^{42}$

Selective transfers of firm resources then impose at least two potential harms on nonfavored shareholders. First, the firm suffers a reduction in its amount of resources available to itself and the shareholders as a group. When Acme's managers seek to favor Merit Investments with a transfer of cash from Acme's bank account, Acme's total value drops. To the extent the payment is non-pro rata, the transfer results in a net decrease in value for some shareholders matched with an increase in value for the recipient shareholders.

Second, the reduction in resources may affect the firm's ability to fund new and ongoing projects. With a lower amount of cash reserves, Acme will have a reduced ability to initiate new research projects or enter into new product markets, for example. To the extent the firm's projects have a positive net present value, however, the firm may go to the capital markets and other sources of funding to finance the projects. In situations where imperfect capital markets exist, nevertheless, the reduction in resources in the firm may leave the firm without adequate resources to pursue even positive net present value projects. Firm value therefore suffers an indirect loss equal to the expected return from the foregone projects. ${ }^{43}$

41. Note that a large-scale repurchase of the shares of public shareholders may be characterized as a repurchase tender offer. As a tender offer, such transactions are then subject to federal securities regulation under the Williams Act. The "Williams Act" refers to Pub. L. No. 90-439, 1968 U.S.C.C.A.N. (82 Stat. 454) 2811 (codified as amended at 15 U.S.C. $\$ \S 78 \mathrm{~m}(\mathrm{~d})-78 \mathrm{~m}(\mathrm{e}), 78 \mathrm{n}(\mathrm{d})-78 \mathrm{n}(\mathrm{f})$ (2000)). For a discussion of the issues surrounding the regulation of repurchase tender offers, see Michael Bradley \& Michael Rosenzweig, Defensive Stock Repurchases, 99 HaRv. L. REv. 1377, 1384-87 (1986).

42. Merit, of course, must know enough not to tender its shares. Some form of selective disclosure must therefore occur from management to Merit. For a discussion on the limits of firms to engage in selective disclosures, see infra Part II.A.6.

43. Note that this capital reduction may also be true for pro rata distributions, but it can be particularly salient in non-pro rata repurchases, particularly when the recipient shareholder is a potential competitor. See infra note 56 (discussing a similar point with respect to Sinclair Oil Corp. v. Levien, 280 A.2d 717 (Del. 1971)). 
Of those transactions discussed above, a feature that distinguishes outright cash distributions from other types is the ease with which they can be observed and verified in court. Indeed, assessing a direct cash distribution requires only that one observe the amount of dollars transferred. Once this amount is known, no other uncertainty exists as to the value of the transfer. In contrast, when assessing transactions that involve a more indirect transfer of value to a block shareholder (such as a share repurchase at a premium) courts must compare the contracted price with the prevailing market price to determine whether the firm transfers any value to the shareholder. In a share repurchase, courts must assess the price paid against the value of the shares; even so, the presence of a liquid secondary market for most publicly held corporations provides courts with an easily observable market price to use as a proxy for share value. ${ }^{44}$ Perhaps accordingly, both courts and regulators are quickest to scrutinize non-pro rata cash transfers, and do so in at least four ways.

First, federal tax law imposes a cost on all forms of distributions of cash and property, whether pro rata or not. Consider the direct distribution of cash and property to shareholders. To the extent a corporation has positive earnings and profits, shareholders must treat the transfer of cash or property from the corporation as a dividend, taxable at ordinary income rates. ${ }^{45}$ Even shareholders of corporations without sufficient earnings and

44. Whether the market price in fact is a good proxy for share value depends on whether the market price in fact incorporates all available information related to the value of the share. The efficient capital market hypothesis provides one justification for this assumption.

Several versions of the efficient market hypothesis exist. The strong form of the hypothesis holds that all information, whether public or nonpublic, is incorporated in the secondary market securities price. The semi-strong version of the efficient capital markets hypothesis in turn posits that the secondary market price of companies reflects all publicly available information on the company. See Eugene F. Fama, Efficient Capital Markets: A Review of Theory and Empirical Work, 25 J. FIN. 383 (1970) (providing a survey of theoretical implications of efficient markets and empirical testing of the efficient markets hypothesis). See also Daniel R. Fischel, Efficient Capital Markets, the Crash, and the Fraud on the Market Theory, 74 CORNELL L. REv. 907, 911-12 \& n.11 (pointing out that "[t]he empirical evidence to date (with some exceptions) appears to establish the validity of the weak and semi-strong versions but not the strong form of the efficient capital markets hypothesis"). Unless otherwise specified, the Article utilizes the term "efficient market" to refer to a trading market that displays features of a semi-strong cfficient market.

Others have argued that markets are not efficient because of investor irrationalities and cognitive limitations in processing information. See Donald C. Langevoort, Theories, Assumptions, and Securities Regulation: Market Efficiency Revisited, 140 U. PA. L. REv. 851, 853-54 (1992); Lynn A. Stout, Are Stock Markets Costly Casinos? Disagreement, Market Failure, and Securities Regulation, 81 VA. L. REV. 611, 648-50 (1995) (reporting skepticism on the part of financial economists on the validity of the efficient market hypothesis).

45. Under Section 30 l(c)(1) of the Internal Revenue Code, distributions considered a "dividend" are taxed as ordinary income. I.R.C. $\$ 301$ (c)(1) (1994). Section 316 then defines a dividend as a distribution to the extent of available current and accumulated earnings and profits. I.R.C. $\S 316$. 
profits must pay taxes at capital gains rates to the extent the total amount they receive from the corporation exceeds their individual bases in the corporation's stock. ${ }^{46}$ The tax on distributions from the corporation therefore reduces the value of direct transfers to shareholders. For every dollar a manager uses to favor a particular shareholder, the shareholder receives much less than a dollar due to taxes. ${ }^{47}$

Second, in the context of share repurchases for cash, pro rata repurchases generally are treated the same as a direct distribution of cash and property for tax purposes. ${ }^{48}$ For non-pro rata repurchases, however, selling shareholders usually face (more favorable) capital gains treatment for any excess price paid above their basis to the extent the repurchases are substantially disproportionate. ${ }^{49}$ Nonselling shareholders that gain disproportionate value as a result of repurchases from others may also face taxation. ${ }^{50}$ Interestingly, then, disproportionate repurchases that favor

Although not formally defined in the tax code, the earnings and profits concept attempts to track the total capital surplus within the corporation. See JACOB MERTENS, JR., THE LAW OF FEDERAL INCOME TAXATION § 38C:01 (1997) (defining earnings and profits as "an economic concept the tax law utilizes to approximate a corporation's power to make distributions in excess of shareholders' initial investments"). Adjustments to earnings and profits are provided under Section 312. I.R.C. $\$ 312$.

46. See I.R.C. § 30I(c)(2), (3).

47. Although note that nonprofit shareholders pay no taxes on investment gains, among other things. See I.R.C. $\$ 501(\mathrm{c})(3)$.

48. See I.R.C. § 302(b)(1); United States v. Davis, 397 U.S. 301, 312 (1970) ("Congress clearly mandated that pro rata distributions be treated under the general rules laid down in $\$ \$ 301$ and 316 rather than under $\$ 302$, and nothing suggests that there should be a different result if there were a 'business purpose' for the redemption.").

49. See I.R.C. $₹ 302(\mathrm{~b})(2)$ (providing that a distribution to a particular shareholder is disproportionate if "the ratio which the voting stock of the corporation owned by the shareholder immediately after the redemption bears to all of the voting stock of the corporation at such time, is less than $80 \%$ of ... the ratio which the voting stock of the corporation owned by the shareholder immediately before the redemption bears to all of the voting stock of the corporation at such time"). Repurchases that are "not essentially equivalent to a dividend" are also granted basis return and preferential capital gains treatment. I.R.C. $\S 302(b)(1)$. Repurchases that completely terminate the shareholder's interest in the firm or result in a partial liquidation of the corporation also receive such favorable tax treatment. See 1.R.C. $\$ 302($ b)(3), (4).

50. See I.R.C. $\S 305(b)(2)$, (c); Treas. Reg § 1.305-3(e), Example (8) (as amended in 1995). See also MERTENS, supra note 45, $\S 38 \mathrm{~B}: 92$ (noting that "periodic redemptions are particularly suspect under the disproportionate distribution rules of Section 305(b)(2)"). Mertens writes:

For example, if pursuant to a plan for periodic redemptions a corporation agrees to redeem up to $5 \%$ of each shareholder's stock each year and some but not all of the shareholders have stock redeemed under this plan, the remaining shareholders' proportionate interests in the assets and earnings of the corporation will be increased. Provided that the cash received by the shareholders who have some of their stock redeemed is taxable under Section 301 , the remaining shareholders will be deemed under Section 305(c) to have received a taxable distribution under Section 305 (b)(2) equal to their proportionate increase in the ownership of the redeeming corporation.

Id. On the other hand, a single isolated redemption will probably not result in the nonredeemed shareholders being deemed as receiving a distribution under Section 305 (c). See id. 
particular shareholders may receive even more favorable tax treatment than pro rata purchases. Nevertheless, to the extent gain exists on the shares, even under the more favorable tax treatment the recipient shareholder must pay some amount of taxes.

Third, state corporate law systematically prohibits virtually all non-pro rata cash distributions to favored shareholders. Typically addressed in the context of dividend payments that favor a dominant shareholder, ${ }^{51}$ state law bans outright any non-pro rata dividends paid to shares of the same class. ${ }^{52}$ Moreover, even when a corporation has several classes of shares and makes correspondingly different dividends to the separate classes, courts frequently apply the stringent "intrinsic fairness" standard to ensure that a dominant shareholder does not benefit at the expense of minority shareholders holdings shares of a different class. ${ }^{53}$ Pro rata cash distributions, on the other hand, have generated far less judicial scrutiny. In Sinclair Oil Corp. v. Levien, ${ }^{54}$ for example, the Delaware Supreme Court declined to overturn a large pro rata dividend that depleted a corporation's liquidity, arguably to the benefit of the parent corporation that was the dominant shareholder. Instead, the Court applied the business judgment rule to the dividend, ${ }^{55}$ holding that absent waste the dividend was not a

51. For a good discussion of the law dealing with controlling shareholders see Mary Siegel, The Erosion of the Law of Controlling Shareholders, 24 DEL. J. CORP. L. 27 (1999).

52. See ERnest L. Folk, Rodman Ward JR., EdWARd P. Welch, \& ANDREW J. Turezyn, FolK ON THE DElaware GenERAl Corporation LAW, Fundamentals $§ 170.2$, at 34-41 (1993). See also JAMEs D. Cox, Thomas LeE HAZEN, \& F. Hodge O'Neal, Corporations 526 (1997) ("the distribution of dividends among shareholders of the same class must be without discrimination and pro rata unless it is otherwise agreed by all"); 11 FLETCHER CYCLOPEDIA OF PRIVATE CORP. $\$ 5352$ (perm. ed. rev. vol. 1995) (stating that dividends generally must be made on a pro rata basis but that "Is]hareholders of closely-held corporations may unanimously agree upon a scheme other than pro rata distribution"); Edward B. Rock \& Michael L. Wachter, Waiting for the Omelet to Set: Match-Specific Assets and Minority Oppression in Close Corporations, 24 J. CORP. L. 913, 921 \& n.22 (1999) (noting that "[i]t would be clearly illegal-and easily challenged—if the majority shareholder paid itself $\$ 1$ per share in dividends, while only paying minority shareholders $\$ .10$ per share").

53. See, e.g., Sinclair Oil Corp. v. Levien, 280 A.2d 717, 721 (Del. 1971) (noting in dicta that a parent corporation that receives an overly large dividend for one class of shares compared with minority shareholders holding another class of shares would face the stringent "intrinsic faimess" standard of court review).

54. 280 A.2d 717 (Del. 1971).

55. Id. at 721-22 (stating that "Sinclair lthe parent] received nothing from Sinven lthe subsidiary] to the exclusion of its minority stockholders. As such, these dividends were not self-dealing. We hold therefore that the Chancellor erred in applying the intrinsic faimess test as to these dividend payments. The business judgment standard should have been applied."). See infra note 60 (describing the business judgment rule). 


\section{violation of the parent corporation's fiduciary duty to the subsidiary's minority shareholders. ${ }^{56}$}

Finally, state corporate law also scrutinizes the managers themselves who cause the payments to be made, imposing upon them the fiduciary duty to act in the best interests of the firm and its shareholders as a group. Managers who force the firm to make a payment to a specific shareholder solely for the purposes of entrenching their own positions would violate that duty of loyalty, and would therefore be subject to liability. ${ }^{57}$ At the same time, demonstrating an actual loyalty violation in court is no simple feat. Unlike situations where managers obviously stand on both sides of the transaction (and where courts apply heavy scrutiny ${ }^{58}$ ), acts of favoritism toward block shareholders do not clearly evince self-interested motives. $^{59}$ In order to proceed on a duty of loyalty claim, then, plaintiffs

56. Sinclair Oil Corp, 280 A.2d at $720-23$ (stating that the intrinsic fairness test for transactions involving a parent and subsidiary corporation will be applied only where self-dealing is present and defining self-dealing as occurring "when the parent, by virtue of its domination of the subsidiary, causes the subsidiary to act in such a way that the parent receives something from the subsidiary to the exclusion of, and detriment to, the minority stockholders of the subsidiary").

The law, however, is not perfect in its attempt to block the ability of corporations to favor shareholders disproportionately even through cash payments. Even pro rata distributions of corporate resources may benefit individual shareholders differentially. Return to the Sinclair Oil case. 280 A.2d 717. Although the minority shareholders received the same pro rata portion of the cash dividend as the parent, the different sets of shareholders may still have had conflicting interests. The parent, for example, may have faced a large liquidity crisis, leading it to remove cash from the subsidiary even where the cash would provide a higher long-term value within the subsidiary. Other minority shareholders lacking such a liquidity crisis may very well have desired to keep the money inside the subsidiary.

57. The fiduciary duty of loyalty forms the core prohibition against managerial appropriation of private benefits. The duty of loyalty prohibits managers from competing against the corporations. Managers may not generally profit at the expense of the corporation. Self-dealing transactions between the managers and the corporation are not allowed unless deemed objectively "fair." See Meinhard v. Salmon, 249 N.Y. 458, 464 (1928) (stating that the duty of loyalty involves "the exercise of the punctilio of an honor the most sensitive"). See generally CLARK, supra note 1, $\S 18.4$ (describing the duty of loyalty under state corporate law). Self-dealing transactions lose the more favorable business judgment standard of review. Instead, courts apply the much more stringent "entire fairness" standard. See, e.g., Weinberger v. UOP, Inc., 457 A.2d 701, 710-11 (Del. 1983). Delaware, nevertheless, allows managers to cleanse a self-dealing transaction through a variety of procedural means, including a vote on the part of disinterested directors or shareholders. See DEL CODE ANN. tit. 8, $\$ 144$ (1991).

58. See Heckmann v. Ahmanson, 168 Cal. App. 3d 119, 128, (1985) (describing appropriate judicial scrutiny the court stated, "Once it is shown a director received a personal benefit from the transaction ... the burden shifts to the director to demonstrate not only the transaction was entered in good faith, but also to show its inherent fairness from the viewpoint of the corporation ....").

59. Several corporate welfare enhancing motivations may lie behind favoring shareholders selectively. For example, firms may seek to subsidize the formation of blocks of shares that may have a greater incentive and ability to monitor managers for agency problems. Without more, therefore, the mere flow of payments to a block shareholder does not necessarily imply opportunism. Moreover, even where opportunism exists, the support of the block shareholder for management is often indirect and 
must be able to demonstrate a sufficient nexus between the act of patronage and managers' personal interests, or risk dismissal under the business judgment rule. ${ }^{60}$ Moreover, complaining shareholders must navigate a tedious and complicated set of procedural hurdles associated with asserting such claims derivatively-hurdles that become more difficult to cross in cases where the alleged disloyalty is relatively attenuated. ${ }^{61}$

The ability of managers to play favorites without violating their fiduciary duties, therefore, turns in part on their ability to obscure their selfdealing motives from courts, usually by burying the transfer within a larger transaction. While share repurchases would seem to be one way to obscure a naked transfer, any premium above market price is also a relatively easy red flag to which plaintiffs may point. ${ }^{62}$ And thus, even though courts have

therefore hard to observe. Block shareholders, for example, may support management through votes in subsequent proxy contests.

60. Delaware's statement of the business judgment rule is represented in Smith v. Van Gorkom, 488 A.2d 858, 872 (Del. 1985):

Under Delaware law, the business judgment rule is the offspring of the fundamental principle, codified in 8 Del. C. $\$ 141$ (a), that the business and affairs of a Delaware corporation are managed by or under its board of directors. In carrying out their managerial roles, directors are charged with an unyielding fiduciary duty to the corporation and its shareholders. The business judgment rule exists to protect and promote the full and free exercise of the managerial power granted to Delaware directors.

Id. at 872-73 (citations and footnote omitted). See also Aronson v. Lewis, 473 A.2d 805, 812 (Del. 1984); 3A FletChER CyClOPEDIA, supra note 52, $\S 1036$ (describing the application of the business judgment rule). In Aronson the court stated that the business judgment rule:

is a presumption that in making a business decision the directors of a corporation acted on an informed basis, in good faith and in the honest belief that the action taken was in the best interests of the company. Absent an abuse of discretion, that judgment will be respected by the courts. The burden is on the party challenging the decision to establish facts rebutting the presumption.

Aronson, 473 A.2d at 812 . Plaintiffs that seek to allege waste face a high hurdle:

Where waste of corporate assets is alleged, the court, notwithstanding independent stockholder ratification, must examine the facts of the situation. Its examination, however, is limited solely to discovering whether what the corporation has received is so inadequate in value that no person of ordinary, sound business judgment would deem it worth what the corporation has paid.

Saxe v. Brady, 184 A.2d 602, 610 (Del. Ch. 1962).

61. A manager's duty of loyalty is technically owed to the firm, and thus the firm enjoys the sole right to pursue such suits. See Clark, supra note 1, \$15.1 (1986); DeBORAH A. DEMOTT, Shareholder Derivative ACtions: LAW AND PRACTICE $\$ 1: 01$ (1987) (stating that "[d]erivative litigation is a uniquely complicated form of civil litigation, in part simply because the real party in interest in the litigation, the corporation, is not the plaintiff'). Consequently, a plaintiff must first demand that the board pursue the action (which is often unlikely), or the plaintiff must successfully claim that making a demand was excused, as it was futile. See Carol B. Swanson, Juggling Shareholder Rights and Strike Suits in Derivative Litigation: The ALI Drops the Ball, 77 MINN. L. REV. 1339, 1349-56 (1993) (describing the demand requirement, excuse, and waiver of demand). Although what makes demand futile varies across jurisdictions, most jurisdictions require some degree of involvement in the challenged transaction on the part of the board assessing the demand. Id. at 1351.

62. See supra text accompanying note 44 (discussing the efficient capital market hypothesis justification for the assumption that the market price reflects the value of a firm). 
accorded presumptive validity to share repurchases on terms deemed "fair" to the corporation, ${ }^{63}$ the inability to disguise a premium over market price makes it significantly harder for managers executing non-pro rata repurchases either to invoke the business judgment rule or to rely on procedural hurdles in order to forestall litigation. As such, managers have turned, over time, to less telltale forms of favoritism, which we take up below. ${ }^{64}$

\section{Loans and Capital Contributions}

From time to time, it is typical for firms like Acme to require additional capital in order to fund new and ongoing endeavors. In such situations, Acme might choose to seek funding from any number of sources, including internally generated funds, bank loans, and capital markets. $^{65}$ If, however, Acme's management team also wishes to conceal favoritism toward a shareholder like Merit, it may often be possible to do so as a part of the terms of a loan executed directly with Merit. In a similar vein, Acme might be able to issue additional securities to Merit in return for hard capital.

In any transaction between a firm and one of its shareholders, the potential for favoritism obviously exists. In this case, for example, Acme might agree to pay an excessively large interest rate, or otherwise provide Merit with new securities at a discounted price for securities issued in return. Suppose once again that Merit owned 1 million of Acme's 10 million shares outstanding. So long as it has sufficient treasury shares, Acme may decide to sell 1 million additional shares to Merit in return for $\$ 50$ million (or fifty dollars per share). After the transaction, Acme will have a market capitalization of $\$ 1.05$ billion and 11 million shares outstanding, resulting in a $\$ 95.46$ per share value. Although Merit loses along with all other shareholders on the shares held prior to the sale, Merit

63. See Cheff v. Mathes, 199 A.2d 548 (Del. 1964) (applying heightened judicial scrutiny to greenmail agreements). See also Viacom Int'l lnc. v. Icahn, 946 F.2d 998 (2d Cir. 1991); Grobow v. Perot, 539 A.2d 180, 191 (Del. 1988) (upholding a greenmail repurchase of shares because the terms were "fair").

64. While it may still sometimes be possible for managers to pay patronage by purchasing others' shares at below-market prices, the factual premises needed to convince shareholders to sell at a discount (such as private information about firm value) are somewhat uncommon.

65. See Lynn A. Stout, The Unimportance of Being Efficient: An Economic Analysis of Stock Market Pricing and Securities Regulation, 87 MICH. L. REV. 613, 648 (1988) (noting that "[internal o]perating revenues finance an average of $61 \%$ of corporate expenditures") (citing R. BREALEY \& S. Myers, Principles of Corporate Finance 29l, table 14-3, (2d ed. 1984)). For a discussion of the disadvantages of relying on bank financing or internally generated funds, see Bernard Black, The Legal and Institutional Preconditions for Strong Securities Markets, 48 UCLA L. REV. 781, 832 (2001). 
also gains $\$ 45.46$ on each share that it purchases. All told, then, Merit's net benefit from the transaction is equal to $\$ 40.9$ million. $^{66}$

Although raising capital from a favored shareholder at discount prices also faces several legal obstacles, such obstacles appear to be somewhat less prohibitive than those applicable to direct payments. First, no direct tax consequences affect Merit Investments from this transaction. Merit loses some value on its preexisting shares and more than makes up for it on the discounted shares it purchases in the above example. The gain on the shares to Merit, under present federal tax law, is not realized until Merit actually disposes of the shares. ${ }^{67}$ So long as Merit holds onto the shares, the gain will remain unrealized and therefore nontaxable. Compared with direct payments of cash or property, managers may therefore transfer a greater amount of corporate value to a particular shareholder through the issuance of new securities. Recipient shareholders that seek to convert this value into cash, however, will eventually face tax consequences when they sell their shares. ${ }^{68}$

Second, while fiduciary duties still constrain self-interested decisions to raise capital, the practical reach of those duties is somewhat constrained by a court's limited ability to observe and verify the manager's intent to self-deal in the issuance of securities. Unlike direct distributions of cash or property, it is much harder to detect a non-pro rata distribution in the context of raising capital through issuing new securities. Indeed, not only do such transactions carry the pretext of having a legitimate purpose, ${ }^{69}$ but Acme managers can often also demonstrate legitimate justifications for the

66. Merit loses $\$ 4.54$ on each of its initial I million shares (for a total loss of $\$ 4.54$ million) but gains $\$ 45.46$ on each of the new I million shares it purchases (for a total gain of $\$ 45.46$ million). The net gain to Merit is therefore equal to $\$ 40.9$ million.

67. The realization requirement under federal tax law requires that a sale or exchange, among other possible realization events, must occur before the gains or losses on an asset are recognized for tax purposes. See 1.R.C. $\$ 1001$ (1994). See also WiLliam A. KLEIN \& JosePH BANKMAN, Federal INCOME TAXATION 27I (1 l th ed. 1997).

68. Because sales may occur in the future, the shareholder still benefits from the deferral of tax consequences.

69. Indeed, evidence exists that the market reacts favorably to news of an equity private placement. See Sophie Hopper Wruck, Equity Ownership Concentration and Firm Value: Evidence from Private Equity Financing, 23 J. FIN. ECON. 3, 8-9 (1989) (finding a positive secondary market reaction to news of an offering in a study of equity private placements into the United States from 1979 to 1985). In particular, where share concentration increases as a result of the offering, the secondary market reaction is even more positive. See id. at 10-23 (arguing that greater share concentration leads both the increased monitoring of management and a raised probability of an eventual takeover). Wruck theorizes that private equity placements typically involve a fewer number of purchasers able to negotiate with management for access to nonpublic information to gauge the value of the company. See id. at 10. 
apparent discount given to Merit. For example, U.S. securities laws severely limit the ability of purchasers to resell securities purchased through a private placement, ${ }^{70}$ and thus part of the discount Merit receives could represent compensation for future illiquidity. Additionally, the decision to raise capital may send an adverse signal that managers believe the company to be overvalued, or reveal a liquidity crisis within the firm. Such a signal would cause any purchaser to demand a discounted price. ${ }^{71}$ Viewed in this light, preexisting shareholders (such as Merit) who are relatively familiar with the company are somewhat less vulnerable to such signals. As such, these investors-while still demanding a discountmight nonetheless require less of one than would third parties not already familiar with Acme's operations. ${ }^{72}$ With such readily available justifications, managers stand a good chance of defending discounted sales to a block shareholder under fiduciary principles even where the stated justification is simply a pretext.

Finally, capital market transactions with block shareholders face only minimal scrutiny from federal securities laws. For private placement transactions with a specific shareholder, the securities laws provide a safe harbor under Regulation $D^{73}$ of the Securities Act of 1933 ("Securities Act"), ${ }^{74}$ imposing only minimal disclosure requirements. Under the Securities Exchange Act of 1934 ("Exchange Act"), ${ }^{75}$ reporting companies that seek to raise capital through a private placement only need to furnish their most recent annual Form $10-\mathrm{K}$ filing to purchasers, among other

70. Securities sold through private placements are typically referred to as "restricted" securities. Absent an exemption from the public registration requirements of the securities laws, investors may not resell restricted securities without engaging in a registered public offering. SEC Rule 144 provides one such exemption. 17 C.F.R. $\$ 230.144$ (2001) Under Rule 144, investors must hold their restricted securities at least one year, among other requirements, before engaging in resales. Id.

71. See Stewart Myers and Nicholas S. Majluf, Corporate Financing and Investment Decisions When Firms Have Information That Investors Do Not Have, 132 J. FIN. EcoN. 187, 219-20 (1984) (describing the incentive of managers to sell securities where the secondary market price overvalues the company relative to its fundamental value).

72. Because the comparison is between the discount the preexisting shareholders actually negotiate against what discount, hypothetically, outside investors would have demanded for the same securities, courts may have difficulties in observing the reduction in discount that preexisting shareholders may demand. For example, a preexisting shareholder may negotiate a discount of $15 \%$. Without more, this discount seems large in magnitude. However, where the firm's next best alternative is to issue equity to an outsider at a $20 \%$ discount, the firm in fact saves $5 \%$ in financing costs by issuing the securities to the preexisting shareholder.

73. 17 C.F.R. $\$ \$ 230.501-230.508$.

74. 15 U.S.C. $\$ 77 \mathrm{a}-77$ aa $(2000)$. Regulation D provides a safe harbor for private placements pursuant to Sections 3(b) and 4(2) of the Securities Act. See 17 C.F.R. $\$ \$ 230.504,230.506$.

75. 15 U.S.C. $\$ 78$. 
things. ${ }^{76}$ To the extent the shareholder is considered an accredited investor, moreover, firms are not affirmatively required to disclose any information. ${ }^{77}$ Block shareholders that own greater than $5 \%$ of any outstanding class of equity securities, on the other hand, face disclosure requirements under the Williams Act. ${ }^{78}$

It is difficult to justify (at least on first principles) the differential degree of regulation that governs capital market transactions versus direct payments. Indeed, the risk of opportunism in the two types of transactions seems strikingly similar. In theory, managers may opportunistically transfer just as much corporate value through the issuance of securities as through the direct distribution of cash or property to a particular shareholder. Although the corporation does not directly suffer a reduction in capital on its books, it does bear a loss relative to the value it would have obtained had the securities been sold at a fair market price. ${ }^{79}$ The cash

76. See 17 C.F.R. \$ 230.502(b)(2)(ii). See also 15 U.S.C. \$7. Form 10-k, available at http:/www.sec.gov/divisions/corpfin/forms/10k.htm (as of Dec. 23, 2001).

77. See 17 C.F.R. $\$ 230.502$ (b)(1) (noting however that "[w]hen an issuer provides information to investors pursuant to paragraph (b) 1 , it should consider providing such information to accreditcd investors as well, in view of the anti-fraud provisions of the federal securities laws"). Accredited investors are defined to include investment companies registered under the Investment Company Act of 1940 , corporations with total assets in excess of $\$ 5$ million, and any natural person meeting minimum net worth or income requirements. See 17 C.F.R. $\$ 230.501$ (a).

Regulation $\mathrm{D}$ imposes a number of additional requirements. Among such requirements is the requirement that the issuer not engage in "general solicitations." See 17 C.F.R. § 230.502(c). Private placements pursuant to Rule 504 that are "exclusively in one or more states that provide for the registration of the securities, and require the public filing and delivery to investors of a substantive disclosure document before sale, and are made in accordance with those state provisions" (among other exceptions) are exempt from the prohibitions on general solicitations. See 17 C.F.R. $\$ 230.504$ (b)(1). In discussing the scope of the general solicitation requirement, Donald Langevoort writes that:

[T] he SEC has adhered to a subtextual principle: any "general solicitation" of investors is necessarily inconsistent with the notion of a nonpublic offering. In other words, one cannot advertise or otherwise cast one's net broadly in the hopes of finding qualified investors, but instead must solicit only those whom, based on some pre-existing relationship, one has good reason to believe do not need the protection of the registration requirement.

Donald C. Langevoort, Angels on the Internet: The Elusive Promise of "Technological Disintermediation" for Unregistered Offerings of Securities, 2 J. SMALL \& EMERGING BuS. L. 1 (1998). The general solicitation requirement may therefore channel issuers seeking to raise a small amount of capital quickly to turn to a preexisting investor in the company.

78. The Williams Act requires persons with a beneficial ownership interest of more than $5 \%$ in a class of a firm's equity to make a Schedule 13D disclosure filing with the SEC pursuant to Section 13(d) of the Williams Act and the SEC's own rules and regulations. See 15 U.S.C. $\$ 78 \mathrm{~m}(\mathrm{~d})(1)$. Among the required disclosure items include the identity of the owner, the source and amount of the funds used to make the purchase, and any plans the owner may have to liquidate, merge, and make a major change to the corporation if the purpose of the owner is to acquire control. See 15 U.S.C. $\S 78 \mathrm{~m}(\mathrm{~d})(1)(\mathrm{A})-(\mathrm{C})$.

79. All shareholders of the corporation suffer pro rata from this loss in potential value. 
infusion from the offering proceeds, moreover, may provide managers with a greater ability to siphon off resources for their own personal uses.

Moreover, by channeling managers toward this less regulated mechanism for favoritism, the existing legal regime may have created even greater inefficiencies. Indeed, bestowing patronage through the issuance of shares may impose additional costs that are not present with a direct payment of cash or property. First, although Merit may have some informational advantage over the outside market in valuing Acme, Merit still suffers from an informational disadvantage, compared with the management team itself, on the exact value of the firm. To the extent the block shareholder is wary that the firm's managers may in fact be selling overvalued securities, the shareholder will demand an additional discount for the risk it bears. Moreover, the issuance of new shares will cause the purchasing shareholder to increase its undiversified ownership of securities in the firm. ${ }^{80}$ The shareholder will therefore raise its level of firm-specific risk and require a larger discount in compensation. ${ }^{81}$ In light of these added costs, the systematic discouragement of direct payments may well have induced an alternative outcome that is even more inefficient.

\section{Interested Transactions}

Another mechanism that is often available for benefiting select shareholders consists of more garden-variety business relationships. A firm might, for example, hire representatives of a block shareholder as employees, or to provide independent contracting services. Where a block

80. In addition, the federal securities laws restrict the ability of investors that purchase shares through a private placement to resell the shares (termed "restricted shares") immediately. Rather, the investors must either have the issuing corporation register the shares under Section 5 of the Securities Act or the investors must find an exemption from Section 5 to resell the shares. See 15 U.S.C. $\S 78 \mathrm{e}$. For example, investors may resell restricted shares pursuant to Rule 144 of the Securities Act to the extent the investors, among other requirements, hold onto the shares for at least a one-year period. See 17 C.F.R. \& 230.144. Investors in private placements within the United States, therefore, face an illiquidity risk during the period in which resales are prohibited and will demand a greater discount from the issuer to compensate for this illiquidity.

81. Empirical evidence exists that shares sold through a private placement typically are sold at a large discount from the issuer's current secondary market price. See Michael Hertzel \& Richard L. Smith, Market Discounts and Shareholder Gains for Placing Equity Privately, 48 J. FIN. 459, 478 (reporting a 35\% mean discount for equity private placements of greater than $\$ 25$ million in securities); William L. Silber, Discounts on Restricted Stock: The Impact of Illiquidity on Stock Prices, Fin. ANALYSTS J., July-Aug. 1991, at 60 (reporting a 33.75\% mean discount for a sample of equity private placements involving 69 issuers). 
shareholder operates a separate line of business, the firm may also transact for the provision of goods and services from the separate business. ${ }^{82}$

Where the transactions occur at prevailing market rates, the shareholder acts as any other market provider. Firms will utilize the shareholder as opposed to other providers of goods and services only to the extent the shareholder provides greater value than the other providers. ${ }^{83}$ Not all transactions, however, occur on market-based terms. Managers that seek to favor a particular shareholder may do so through a contract that provides the shareholder terms more favorable than in the market. Suppose, for example, that Merit operates a temporary financial analyst service, providing consulting services for a fee. Acme could employ Merit's analysts at higher than market rates, thereby shifting value from Acme to Merit.

As with direct payments of cash and property, legal limits exist on the ability of firms to favor particular shareholders through interested transactions. Once again, however, the limits are not as stringent in practice as those facing direct payments. Tax law does provide some limitations on these forms of business transactions. Although not formally a dividend, federal tax law may recharacterize an interested transaction as a "constructive dividend," forcing the corporation to lose a potential business expense deduction for the payment ${ }^{84}$ and, to the extent the shareholder otherwise would not face a tax on the payment, ${ }^{85}$ rendering the premium

82. For example, Ed Rock details the relationship between General Motors and the Du Pont Company, which was a major shareholder in General Motors in the first half of the 1900s. See Edward B. Rock, Controlling the Dark Side of Relational Investing, 15 CARDOZo L. REv. 987, 995-97 (1994) (providing examples of "bad" relational investing where the outside large shareholder uses its influence to obtain private benefits). Du Pont served as a major supplier to General Motors during the time period and kept many Du Pont people within General Motors to keep "tabs on the amount of GM business going to Du Pont and the amounts placed with Du Pont's competitors." Id. at 997.

83. In many situations, for example, a firm's shareholders may act as the best outside source for a particular good or service. A firm's shareholder, for example, may have better information than others about the particular needs of the firm and therefore enjoy a greater ability to tailor its goods and services for the firm. As well, a firm may place greater credibility in a shareholder that it knows well and that has an incentive derived from its share ownership to want the firm to succeed compared with other outside providers of a good or service.

84. Note that the loss of a business deduction to the corporation ultimately reduces overall corporate value and thereby hurts all shareholders on a pro rata basis.

85. For example, where the corporation pays for a shareholder's "expenses" made on behalf of the corporation, the shareholder ordinarily would not have to pay taxes on the payments as income. See I.R.C. $\$ 62(a)(2)(A)$ (1994) (providing for the deductibility of reimbursed business expenses paid to an employee from gross income). 
over market price as taxable to the shareholder. ${ }^{86}$ Tax officials seeking to apply the constructive dividend doctrine, however, face a challenge when the good or service at issue is sold within a thin market. ${ }^{87}$ For here, in order to detect a premium, courts must first determine the fair market value against which to measure the contractual price. In the absence of a wellestablished market, this determination is fraught with inaccuracy, and perhaps consequently, many courts tend to err on the side of resisting the constructive dividend doctrine, except in extreme and egregious cases. ${ }^{88}$ This obfuscatory advantage of thin market transactions provides managers with a limited cover to bestow patronage through business transactions - at least on the margin-without triggering the law's scrutiny. ${ }^{89}$

86. For a description of the constructive dividend doctrine, see MERTENS, supra note $45, \S 38: 47$ (noting that "[b]y their nature constructive dividends must be determined by the facts and circumstances of a particular case").

87. Courts also provide a higher level of scrutiny on transactions involving closely held corporations where the shareholder also acts as a director of the corporation. See, e.g., Seminole Thriftway, Inc. v. United States, 42 Fed. Cl. 584, 590 (Fed. Cl. 1998) (noting that "closely-held corporations are operated by their shareholders, who often take on the management roles of officer and director in order to serve their shareholder interest"). Managers of publicly held corporations that use interested transactions to favor particular outside shareholders may therefore have an easier time to avoid the constructive dividends doctrine.

88. Many cases that actively recharacterize interested transactions as a constructive dividend involve egregious fact patterns. See Frazier v. Comm'r, 85 F.3d 640 (10th Cir. 1996) (unpublished table decision) (treating corporate payments for a CEO-shareholder's travel and entertainment expenses, including payments for the CEO's spouse's expenses as well as for visits to friends and relatives, as a constructive dividend where the expenses were primarily for the CEO's personal benefit); Hardin v. United States, 461 F.2d 865, 872-73 (5th Cir. 1972) (holding that payments by a corporation to the widow of a shareholder's brother as a constructive dividend to the shareholder where the corporation had never paid a formal dividend, the widow was not a shareholder of the corporation, and the corporation owed no formal legal obligation to the widow); Estate of Chism v. Comm'r, 322 F.2d 956, 956 (9th Cir. 1963) (upholding a tax court decision treating "loans" from a corporation to shareholders as a constructive dividend where the loans were never "evidenced by promissory notes or other written instruments, no interest was ever paid or charged on the outstanding balance, and no collateral security was ever given for them," no expectation for repayment exists, and the corporation had never paid any formal dividends); Seminole Thriftway, Inc., 42 Fed. Cl. at 591 (treating fees paid to shareholders for their guarantee of a loan to the corporation as a constructive dividend because the fees were paid many years after the guarantee was actually given and thus were not required to obtain the guarantee). Cf. Alpha Medical, Inc. v. Comm'r, 172 F.3d 942 (6th Cir. 1999) (holding all of a sole shareholder's payment from the corporation of $\$ 4.4$ million for work done as president of the corporation as deductible compensation and not a constructive dividend because "reasonable shareholders ... would have agreed to [the shareholder's] level of compensation" because of the shareholder's "accomplishment, the risks he assumed, and the amazing growth [in the corporation]").

89. Because of the emphasis on whether an "arms-length" transaction took place, shareholders and the corporation have a greater ability to avoid recharacterization as a constructive dividend to the extent formalities are followed. In addition, because of the lack of precision in determining when a payment to a shareholder truly is a constructive dividend, a corporation may seek to spread an intended dividend to a shareholder across many different forms of interested transactions to avoid the scrutiny of 
State fiduciary law also limits the ability of managers to engage in interested transactions where the managers benefit at the expense of shareholders. As a practical matter, however, the deterrent effect of state law is relatively limited in scope. Ordinarily, when a firm engages in an interested transaction with a dominant shareholder, courts treat such transactions as presumptive self-dealing, applying intensified scrutiny to the transaction. ${ }^{90}$ However, many block shareholders are not currently "dominant" under conventional definitions due to their lack of a $50 \%$ or more ownership stake or explicit control over the corporation. ${ }^{91}$ In such

the IRS. See, e.g., An Introduction to Business Entities, WFT-BUSENT Ch. 10 Doc. 4, at 2001 WL 423413 (US).

If shareholders wish to distribute corporate profits in a form deductible to the corporation, a balanced mix of the possible alternatives lessens the risk of constructive dividend treatment. Rent for the use of shareholder property, interest on amounts borrowed from shareholders, or salaries for services rendered by shareholders are all feasible substitutes for dividend distributions. But overdoing any one approach may attract the attention of the IRS.

Id. See also Exacto Spring Corp. v. Comm'r, 196 F.3d 833, 835 (7th Cir. 1999) (contending that multifactor tests used to determine whether executive compensation in fact should be recharacterized as a constructive dividend "invites the Tax Court to set itself up as a superpersonnel department for closely held corporations, a role unsuitable for courts"). Judge Posner writing for the Seventh Circuit in Exacto Spring Corp. instead followed an "independent investor" test under which a court must ask whether a passive, independent investor would pay the compensation. Id. at 838 ("If the rate of return is extremely high, it will be difficult to prove that the manager is being overpaid, for [replacing the manager with a lower-paid manager] ... would be killing the goose that lays the golden egg."). While avoiding the pitfalls of having courts determine proper compensation levels, the independent investor tests gives great leeway to companies earning superior returns for investors to disguise dividends as compensation.

90. See Zahn v. Transamerica Corp., 162 F.2d 36, 42 (3d Cir. 1947) (holding that a controlling shareholder owes a fiduciary duty to the corporation and its shareholders similar to that of a director); Judah v. Delaware Trust Co., 378 A.2d 624, 628 (Del. 1977) ("Where the majority shareholders stand to benefit at the direct expense of the minority shareholders by action of a board of directors they control, the backdrop provided by the fiduciary obligations owed by the directors to the minority requires that the proposed action be closely examined before being effectuated."). See also FLETCHER, supra note $52, \S 5811.10$ ("When a majority, dominant or controlling shareholder deemed to be a fiduciary is challenged for having engaged in self-dealing in property or services of the corporation, that shareholder has the burden of coming forward with evidence and the burden of persuasion to show that the transaction was scrupulously fair."); $I d$. $\$ 5810$ (noting that "[t]he same fiduciary duty is due from a dominant or controlling shareholder or group of shareholders to the minority as is due from the director of a corporation to the shareholders").

In a transaction between a parent and subsidiary corporation, Delaware, among other jurisdictions, has applied the stringent "entire fairness" standard in reviewing the transaction. See Summa Corp. v. Trans World Airlines, Inc., 540 A.2d 403, 406 (Del. 1988) ("It is well established in Delaware that one who stands on both sides of a transaction has the burden of proving its entire fairness."). But see Sinclair Oil Corp. v. Levien, 280 A.2d 717, 720 (Del. 1971) (stating that the entire faimess standard of review will be applied to a parent-subsidiary transaction only if the parent "receives something from the subsidiary to the exclusion of, and detriment to the minority stockholders of the subsidiary"-and holding that a pro rata dividend did not meet this test).

91. Shareholders with a 50\% or more ownership stake in a corporation's outstanding stock are presumed in control of the firm. For a shareholder that owns less than $50 \%$ of a corporation's 
cases, a finding of self-dealing seems significantly less likely for numerous reasons. First, just as above, it is often difficult to discern whether the challenged transaction really does result in a benefit to the outside shareholder, especially in thin markets. Where the transaction is on purely market-based terms, the outside shareholder benefits no more than from any other market transaction. Furthermore, even where the outside shareholder clearly benefits relative to a market-based transaction, the benefit may actually be demonstratively justifiable. Merit, for example, may possess better expertise than other providers of services in the market, or it may enjoy greater productivity (therefore justifying a higher rate per hour). In addition, as noted above, Merit may have a better understanding of the firm's needs than outside suppliers, giving it a lower cost of providing services for the firm.

As before, the reduced scrutiny of interested transactions compared to direct transfers may channel many managers toward bestowing favoritism through interested transactions. And, just as with sales of securities, this indirect form of transferring benefits may introduce greater inefficiencies as well. Indeed, interested transactions may crowd out contracts between the firm and more efficient providers of a good or service. By hiring Merit to do its financial analysis, Acme may well bypass higher quality or lower cost analysts. From Acme shareholders' standpoint, it would be far better to retain the services of one of these alternative providers, even if Acme subsequently made a side payment to Merit to induce its quiescence. In-kind favoritism, therefore, tends to introduce additional technical inefficiencies, reducing overall corporate welfare. ${ }^{92}$

outstanding stock, whether the shareholder is considered a "controlling" shareholder for fiduciary duty purposes depends on whether the shareholder exercises control over the firm, an issue of fact for the court to determine. See FLETCHER, supra note 52, \$ 5811 (stating that a shareholder with less than 50\% ownership of a corporation's outstanding stock is not considered a controlling shareholder unless there is "some evidence demonstrating control ... since the presumption is against it") (citing Gilbert v. El Paso Co., 490 A.2d 1050, 1055 (Del. Ch. 1984)). See also Lewis v. Knutson, 699 F.2d 230, 235 (5th Cir. 1983) (imposing a fiduciary duty on a shareholder owning only $34.8 \%$ of a corporation because the shareholder exercised "actual control and direction over corporate management"); Kahn v. Lynch Communication Sys., 638 A.2d 1110 (Del. 1994) (holding that a shareholder with a $43.3 \%$ minority ownership interest was a controlling shareholder because of the shareholder's exercise of control over the corporation).

92. Managers might attempt to avoid the crowding out effect by hiring the shareholder for a service that the firm does not otherwise require. Acme, for example, may hire representatives from Merit Investments to conduct worthless "market research" for Acme on the dynamics of the beach scene in the Bahamas, paying Merit an exorbitant fee for the research. Such transactions, however, are arguably just as inefficient given that there are other individuals with modest opportunity costs (such as the authors of this Article) who would be willing to do the same sort of market research at cost. Moreover, such contrived expenditures may begin to look clearly like direct payments, triggering the enhanced legal scrutiny noted above. See supra text accompanying notes 48-56. 
Significantly, the inefficiencies introduced by business transactions with a favored shareholder are likely to increase with the size of the desired transfer. Merit, for instance, may offer only a certain "package" of financial services to the market. Fiduciary duties and market-constraints may then limit the ability of managers to pay too much above the prevailing market-based fee for such a package. ${ }^{93}$ Thus, where Acme's managers seek to use interested transactions to transfer even more to Merit, Acme may need to employ alternative services that Merit is not well equipped to supply. ${ }^{94}$ For example, Acme may very well hire Merit to help manufacture more ten-gallon cowboy hats for Acme's discount mall sales. To the extent Merit's comparative advantage lies in financial services, however, Merit will serve as an ill-suited source for cowboy hats.

Compared with direct selective payments of cash or property, therefore, interested transactions constitute both a less scrutinized and less efficient mechanism for playing favorites. Most immediately, the law provides greater leeway for a firm to favor shareholders with interested business transactions, therefore channeling the firm toward such activities instead of direct distributions. Consequently, the use of interested transactions to generate support will tend to cause the firm to employ technically inferior inputs in their production process, generating even a larger social loss than that which would occur in the context of cash distributions.

\section{Allocation of Opportunities}

A fourth manifestation of shareholder favoritism comes through the allocation of potential business opportunities that the firm has yet to exploit. Such corporate opportunities may arise from any number of sources, such as specific assets and expertise within a firm's scope of control, information learned within the course of the firm's business, or simple happenstance. For some opportunities, such as new potential customers for its existing product line, the firm itself is clearly the highest valuing recipient. Other opportunities, however, may provide profit to a wide variety of different possible recipients. Acme, for example, may learn

93. For example, the firm may pay Merit $\$ 200$ per hour for its analysts as compared with the prevailing market payment of $\$ 100$ per hour. Once the firm starts paying Merit $\$ 1,000$ per hour or higher, however, the firm may attract unwanted scrutiny from potential hostile acquirers, tax officials, and plaintiffs' attomeys seeking to initiate a fiduciary duty suit.

94. See An Introduction to Business Entities, supra note 89 (which recommends spreading favoritism across a series of different possible interested transactions to reduce the possibility of IRS attention). 
of new valuable mineral resources located on property next to its production facility. Acme could exploit such an opportunity through the purchase of the property itself, or others connected with the firm may appropriate the profit from the mineral find through a purchase of the property. Managers, for example, could increase their private benefits of control through the direct purchase of the property. Managers that desire to benefit a particular block shareholder could also notify the shareholder of the property, giving the shareholder the opportunity to purchase the property.

As with new issues of securities and interested transactions, federal tax laws provide few barriers to the allocation of opportunities. Because shareholders engage in no direct transactions with the firm to obtain the opportunities, no taxable transaction exists (at least with respect to the shareholders' expropriation of the opportunities). General state law fiduciary duties continue to apply under the rubric of the corporate opportunities doctrine. ${ }^{95}$ Courts applying the corporate opportunities doctrine follow a two-stage approach, asking first whether a particular business project in fact is a corporate opportunity and then whether management, in giving an opportunity to a particular outside shareholder, has taken the proper steps in appropriating the opportunity. ${ }^{96}$ Under the most prominent test for whether a business project constitutes a corporate opportunity, courts examine whether the project is in the same "line of business" as the corporation. ${ }^{97}$ Although somewhat vague concerning what constitutes a line of business, courts in applying the line of business test focus on the ability of the corporation to exploit the opportunity, based on the corporation's endowment of resources and expertise. ${ }^{98}$

95. See generally Eric Talley, Turning Servile Opportunities into Gold: A Strategic Analysis of the Corporate Opportunities Doctrine, 108 YALE L.J. 277, 286-310 (1998) (discussing the corporate opportunities doctrine). See also AMERICAN LAW Institute, Principles of Corporate GOVERNANCE: ANALYSIS \& RECOMMENDATIONS $\$ 5.05$ (1994) (defining a corporate opportunity as including "[a]ny opportunity to engage in a business activity of which a senior executive becomes aware and knows is closely related to a business in which the corporation is engaged or expects to engage"). Under the American Law Institute approach, a manager may take a corporate opportunity only to the extent (a) full disclosure is made to the corporation; (b) the eorporation rejects the opportunity; and (c) either the rejection meets a test of total fairness, disinterested directors reject the opportunity in advance, or disinterested shareholders ratify the manager's appropriation of the corporate opportunity. See id.

96. See Talley, supra note 95 , at 286-310.

97. See id. at $\mathbf{2 8 9}$ (stating that the line of business test "pulls within its ambit any project that the corporation-given its current assets, knowledge, expertise, and talents—could adapt itself to pursue").

98. See id. 
Nevertheless, while funneling new business prospects to shareholders may constitute a technical violation of the corporate opportunities doctrine, managers engaging in such activities are unlikely to face a serious risk of liability. First, the manager's self-interested motivation is often difficult to detect, since it is not the manager who ultimately appropriates the opportunity, but rather a noncontrol block shareholder. Courts and other outsiders may have difficulty in distinguishing whether the shareholder obtained the opportunity from the managers or through bona fide competition. When Acme informs Merit of valuable mineral resources on property adjoining Acme, Merit may react through a purchase of the property before news of the mineral resources becomes public. Only Merit's purchase transaction, however, is directly observable to outside parties. Without a clear trail leading back to Acme's tip to Merit, Merit's purchase is consistent with Merit itself engaging in research and uncovering the presence of mineral resources on the land without Acme's assistance. ${ }^{99}$ Moreover, to the extent no direct cash payments occur from the block shareholders to the managers, no evidentiary trail exists to link the shareholder's use of the opportunity with the managers.

Much like the foregoing examples, the use of corporate opportunities to benefit a particular shareholder may introduce several inefficiencies compared with direct payments of cash or property. Suppose, for example, that Acme received an opportunity to enter into a new market for western clothing tailored to women, and the Acme management passed this opportunity on to Merit Investments. Being unfamiliar with the western clothing market characteristics, Merit might view the new opportunity as risky relative to the perception of a well-established market participant like Acme. To the extent that Merit is averse to these risks, it will discount the value of the opportunity it receives. ${ }^{100}$ In addition, Acme's experience in the market also puts it at a comparative advantage to exploit the opportunity. Indeed, Acme's expertise and sunk investments in production technology may make Acme a relatively low cost entrant into the new market. Thus, although Merit may profit from the opportunity, it will not receive as much profit as Acme could itself. The cost to Acme will therefore exceed the benefit transferred to Merit. Once again, the legal attractiveness of using business opportunities to dole out favoritism comes

99. Of course, where the information is clearly the type that only Acme would know, Merit may have a harder time convincing a court that it generated the information independently.

100. For the same amount of dollar benefit Merit receives, therefore, Acme's managers must expend greater resources providing this benefit through the allocation of corporate opportunities compared with outright cash payments. 
with an inefficiency cost that would not be realized in the instance of a cash payment.

\section{Allocation of Business Activities}

Closely related to the granting of interested transactions is the allocation within the firm of resources to particular business activities. Firms engage in all sorts of business activities, from the purchasing of inputs, to the hiring of employees, to marketing, distribution, and ultimate sale of their outputs. The allocation of the firm's resources among these tasks may have significant indirect effects on others' business-including that of a block shareholder.

For example, Acme's cowboy hats might be made out of any number of materials, including straw, wool, felt, and beaver fur. ${ }^{101}$ Suppose that Merit Investments has purchased a large ownership position in one of the chief national producers of wool felt. Acme's managers could indirectly assist Merit by increasing the number of hats they produce composed of felt, thereby increasing the market price of the material and buoying Merit's ownership stake. Alternatively, the managers could have Acme reduce its own in-house production of felt, directing it to buy rather than make the material, which would again increase the overall market price of felt, indirectly benefiting Merit. ${ }^{102}$

Several other means exist for a firm to rechannel its own business activities to benefit one of its shareholders even without an explicit contract. Acme might lobby for regulatory reforms that work to favor investment companies like Merit. Acme could also expend money in developing common resources that benefit the two companies' businesses. For example, Acme may research common technology that benefits both Acme and Merit's businesses and then release the technology into the public domain. Acme may also develop human capital in its workers tailored specifically for the needs of Merit's business, thereby saving Merit the training costs for any employees it hires laterally from Acme. ${ }^{103}$

101. Readers who find their appetites whetted for the purchase of a cowboy hat may refer to the Cowboy Hat Store, at http://www.cowboyhatstore.com (last visited July 10, 2001) for a wide variety of hats.

102. Note that Merit does not necessarily need to purchase from Acme to obtain the benefit of the lower cost. Because the overall market supply has increased, Merit may turn to any supplier to receive a lower price.

103. For example, Acme could expend considerable resources training its own in-house financial analysts using methods of analysis that Merit prefers and then terminate the analysts at the end of training. Merit could then attempt to hire the analysts. Significantly, the tailored expertise in the hands of the analysts will not draw a significant increase in wage from other competing employers to the 
There are virtually no adverse tax consequences that stem from the reallocation of (generally deductible) business expenses within a firm. ${ }^{104}$ As to fiduciary duties, state law limits-at least in theory-a manager's ability to allocate business activities opportunistically. In practice, however, the probability of facing heavy judicial scrutiny is low. As with several of the other forms of opportunistic payments to outside shareholders, managers are not directly benefited. Instead, favored shareholders may repay managers later through their support in proxy voting. ${ }^{105}$ Courts and other outside observers therefore face a challenge in determining whether a particular allocation of business activities in fact constitutes self-dealing. Without hard proof, plaintiffs will find it difficult to rebut the business judgment rule presumption, leaving them with the more daunting task of demonstrating that the directors' decisions constituted waste. ${ }^{106}$ Indeed, because no ready measuring stick exists for evaluating how a firm should allocate its business operations, courts may find it next to impossible to determine whether a particular allocation is driven from a self-dealing motivation.

Almost by definition, the reallocation of business activities within a firm done for the sole purpose of paying patronage introduces productive inefficiencies. Not only is the benefit to the block shareholder highly uncertain and speculative, but each dollar spent on benefiting the block shareholder almost certainly generates less than one dollar's worth of expected benefits. Firms that seek to enter a new product market to benefit a block shareholder, for example, must expend resources designing and advertising the new product. As well, the firm must search for new employees to provide needed expertise related to manufacturing, marketing and distributing the product, among other things. Industries in which

extent the expertise is specific for Merit. Merit may therefore hire the analysts at a fair market wage and profit from lack of any need to expend resources in training the analysts.

104. To the extent no market transaction occurs, the reallocation of assets within a firm would lack the required realization event required for taxation. See supra note 67 (describing the realization requirement). In theory, the expenditures made within the firm solely to benefit an outside shareholder selectively may be viewed as a "business gift" to the extent the firm receives nothing in return. Business gifts are generally not deductible to the donor to the extent such gift exceeds twenty-five. See 1.R.C. \& 274(b) (1994). Nevertheless, the IRS, among others, would find it difficult to recharacterize a shift in internal business activities that results in no direct flow of cash or property to the outside shareholder as a gift.

105. Shareholders typically vote to elect the board of directors, to ratify certain self-dealing transactions on the part of managers, to affirm an amendment to the corporate charter, and to approve (some but not all) mergers involving the corporation, among other things. For a general discussion of shareholder voting, see Jeffrey N. Gordon, Shareholder Initiative: A Social Choice and Game Theoretic Approach to Corporate Law, 60 U. CIN. L. REv. 347 (1991).

106. See supra note 60 (citing Delaware's formulation of the business judgment rule). 
economies of scale exist may require the firm to expand volume rapidly to achieve such economies. ${ }^{107}$

But even beyond these fixed costs, opportunistic reallocation of activities leaves the firm relatively unbalanced in its portfolio of outputs, production technology, and inputs. Accordingly, the total value of the firm will suffer. For example, by supporting an artificially high price in the market for wool felt production, Acme may be required to generate demand by reducing its retail price far below cost, thereby losing money. For the sake of favoring a particular block shareholder, then, managers may shift the firm into activities that have low or even negative net present values. Thus, significant inefficiencies (relative to outright cash distributions) may be an unintended consequence of the relative laxity of legal restrictions on favoritism through business activities.

\section{Disclosure of Nonpublic Information}

Finally, firms at many important junctures are repositories of a wealth of nonpublic information that, once made public, materially affects the trading price of their securities. ${ }^{108}$ Acme, for example, may have nonpublic information that its upcoming quarterly earnings will fall short of market expectations. Investors who learn this information before it is publicly disclosed can reap a significant trading advantage, selling their inventory of Acme's shares at the prevailing (and overvalued) market price. Alternatively, the informed investors could sell Acme's shares short, borrowing shares to sell immediately at the overvalued price and then purchasing shares after the earnings announcement is made at the new lower expected price. ${ }^{109}$ If Acme management sought to favor Merit, then,

107. Indeed, in many industries, high barriers to entry exist. See JOE STATEN BAIN, BARRIERS to New COMPETITION: THEIR ChaRACTER AND CONSEQUENCES IN MANUFACTURING INDUSTRIES (1956) (identifying economies of scale and sunk costs, product differentiation, and absolute cost advantages as three possible barriers to entry). But see Harold Demsetz, Barriers to Entry, 72 AM. ECON. REV. 47 (1982) (questioning the relevance of barriers to entry).

108. Extensive evidence exists, for example, that insiders profit significantly from the use of the firm's nonpublic insider information. See generally Jesse M. Fried, Reducing the Profitability of Corporate Insider Trading Through Pretrading Disclosure, 71 S. CAL. L. REV. 303, 321-22 (1998) (citing several empirical studies showing that insiders earn significant excess returns through insider trading and hypothesizing that "the most plausible explanation for this result is that insiders are trading on information that is not available to the rest of the market").

109. Short sales allow an investor to sell shares that the investor does not own. Investors seeking to execute a short sale first borrow shares from a broker. Then the investor sells the borrowed shares at the prevailing secondary market price, pocketing the cash from the sale. The investor must later repay the borrowed shares through the purchase of new shares in the market. Where the repurchase price is lower than the price the investor initially sold the borrowed shares, the investor profits. 
it might do so by disclosing nonpublic information to Merit selectively before its public announcement.

Several layers of legal prohibitions exist against the provision of selective disclosures in situations where managers seek to entrench themselves. First, state corporate law fiduciary duties nominally prohibit such activity. As before, however, many forms of information disclosure can occur from benign motivations, such as a desire to disseminate information on the company to the market, increasing stock price accuracy to the benefit of all shareholders. ${ }^{110}$ In both cases, neither the manager nor the shareholder receives a detectable payment. As such, it is at least possible that courts would find it difficult to distinguish benign instances of disclosure from opportunistic ones. ${ }^{11}$

Second, the federal securities laws may treat shareholders receiving nonpublic inside information from managers in violation of their fiduciary duty as similar to insiders. The Supreme Court, in Dirks v. SEC, ${ }^{112}$ set forth the test for when a tippee receiving nonpublic material information from a corporate insider faces insider-trading liability. Writing for the Court, Justice Powell held that shareholders who receive a tip from an insider, in a situation where the shareholder knows or should know that the insider is breaching a fiduciary duty, commit insider trading when they trade based on the information. ${ }^{113}$ Justice Powell further elaborated on what constituted a fiduciary breach on the part of a tipper, writing that a breach occurs when "the insider receives a direct or indirect personal benefit from the disclosure, such as a pecuniary gain or a reputational benefit that will translate into future earnings." 14 Despite the theoretical reach of insider trading prohibitions to block the opportunistic use of tips to outside shareholders, enforcement is often problematic due to the difficulty of demonstrating that the manager violated any fiduciary duty where the manager in fact received no direct trading profits.

110. For a discussion of the beneficial uses of selective disclosures, see Stephen Choi, Symposium, Selective Disclosures in the Public Capital Markets, 34 U.C. DAvis L. REv. (forthcoming 2002).

111. For example, Acme's managers may transmit information on Acme's upcoming financials to Merit Investments. Merit, in turn, may trade based on such information for its own profit without sharing anything directly with Acme's managers. Instead, Merit may simply vote for the managers' candidates for directors at the next proxy vote in return. To the extent their relationship is long-term, Merit and the managers may engage in such activity without the need of any formal contractual relationship. Lacking any traceable direct benefit to Acme's managers from the disclosure, courts may find it difficult to discern a fiduciary duty violation.
112. 463 U.S. 646 (1983)
113. See id. at 660 .
114. Id. at 663. 
Third, the SEC has recently promulgated new regulations to block the transmission of material, nonpublic information to selective recipients altogether. Encompassed within Regulation FD, ${ }^{15}$ the new rules define a class of recipients to which the firm, top officers of the firm, as well as employees that speak for the firm may not make selective disclosures. ${ }^{116}$ Among such recipients are broker-dealers, investment companies, investment advisors, and investors that are reasonably expected to trade based on the information. ${ }^{117}$ Regulation FD requires firms that engage in such selective disclosures intentionally to disclose the information immediately to the public markets. ${ }^{118}$ For unintentional disclosures, Regulation FD still requires firms to make the information known to the public markets within twenty-four hours or when trading commences on the New York Stock Exchange, whichever is sooner. ${ }^{119}$

The SEC's approach to selective disclosures differs from the regulatory prohibitions applied to most of the other forms of selective payments to shareholders. Unlike the approach taken for issues of new securities, interested transactions, and the allocation of business opportunities and activities, the SEC's approach does not attempt to divide between opportunistic and more benign forms of payments to shareholders. Instead, Regulation FD resembles the outright prohibition on non-pro rata direct dividends from a corporation to shareholders of the same class. As such, firms seeking to grant favoritism to block shareholders are relatively less likely to do so by selective disclosures than through one of the other mechanisms studied above. ${ }^{120}$

115. See Promulgating Release, supra note 14. Regulation FD represents the culmination of one of former SEC chairman Arthur Levitt's top priorities. See David Schellhase, Arthur Levitt's Cultural Crusade, RECORDER, Aug. 16, 2000.

116. See Regulation FD, 17 C.F.R. $\$ 243.101$ (b) (2001) (defining "issuer" to encompass primarily Exchange Act reporting companies); 17 C.F.R. $\$ 243.101$ (c) (stating that "'Person acting on behalf of an issuer' means any senior official of the issuer..., or any other officer, employee, or agent of an issuer who regularly communicates with any person described in Rule 100(b)(1)(i), (ii), or (iii), or with holders of the issuer's securities.").

117. See 17 C.F.R. $\$ 243.100(\mathrm{~b})(1)$.

118. See 17 C.F.R. $\$ 243.100$ (a)(1) (requiring simultaneous disclosure in the case of intentional selective disclosure).

119. See 17 C.F.R. $\$ 243.100$ (a)(2) (requiring disclosure "promptly" in the case of unintentional selective disclosures); 17 C.F.R. $§ 243.101$ (d) (defining "promptly"). Because of the possibility of nuisance suits, Regulation FD excludes the possibility of private causes of actions based on violations of Regulation FD. See Promulgating Release, supra note 14.

120. We should note that in proposing Regulation FD, the SEC focused much attention on the danger of selective disclosure to analysts (and in particular on the risk that managers may give information selectively to analysts in return for the analysts' willingness to give the company's stock a good recommendation). See Selective Disclosure and Insider Trading, Exchange Act Release Nos. 33 7787, 34-42259, 64 Fed. Reg. 72,590, 72,592 (Dec. 28, 1999). Nevertheless, the scope of Regulation 
In spite of the relatively significant degree of regulation that selective information disclosure faces, it is not altogether clear from an efficiency perspective that such practices always reduce overall corporate welfare. ${ }^{121}$ Firms, for example, may use selective disclosures to subsidize analysts initiating coverage of the firms as well as the formation of blocks of shares that work to monitor the firm for agency costs. Selective disclosures may also provide firms an easy avenue to inform markets without compromising confidential information or exposing the firm to frivolous antifraud lawsuits. ${ }^{122}$ The prohibition on selective disclosures may cause firms to remain silent, inducing some outside analysts to make large expenditures in uncovering similar information on which to make trading profits. ${ }^{123}$ Given that these analysts may not be the lowest cost investigators, the prohibition of selective information may generate unnecessarily high and duplicative research costs in the securities markets.

On the other hand, of course, allowing selective disclosures has its drawbacks as well. Indeed, nonblock outside shareholders would probably expect always to be at a disadvantage relative to a favored recipient, and would therefore pay much less up front than they otherwise would for the firm's shares. Moreover, nonfavored analysts may reduce their coverage of the particular firm (given their disadvantage relative to analysts that receive selective disclosures), increasing the amount of price volatility in the stock and raising the cost to investors of engaging in research related to the firm. Managers will then face a reduced amount of firm resources from which they may appropriate. ${ }^{124}$

FD as promulgated includes investors reasonably expected to trade on the information. See 17 C.F.R. $\S 243.100(\mathrm{~b})(1)$.

121. For a discussion of the beneficial uses of selective disclosures, see Choi, supra note 110.

122. See id.

123. See David D. Haddock \& Jonathan R. Macey, A Coasian Model of Insider Trading, 80 Nw. U. L. REv. 1449, 1463-64 (1986). See also Ian Ayres, Back to Basics: Regulating How Corporations Speak to the Market, 77 VA. L. REV. 945, 992-95 (1991) (describing market specialists as "palace guards" able to learn material corporate information prior to other outside investors).

124. Where firms choose to make selective disclosures to favored block shareholders, various externalities may result in the securities market. To the extent analysts are crowded out through the transfer of inside information to block shareholders, analysts may choose not to engage in as much securities research on the firm. Zohar Goshen and Gideon Parchomovsky make the argument that analysts provide a benefit to all investors from their research activities that they only partially capture. See Zohar Goshen \& Gideon Parchomovsky, On Insider Trading, Markets, and "Negative" Property Rights in Information, 87 VA. L. REV. 1229 (2001). Crowding out analysts, therefore, may hurt the ability of all investors to engage in informed securities analysis. Such investors therefore may pay less for the firm's security when the firm initially raises capital, leaving managers with less money to appropriate. 


\section{B. Practical Problems With Prohibition}

As we noted in the Introduction, the practice of bestowing favoritism on block shareholders (regardless of the precise means for doing so) evokes deep suspicion among many legal scholars. Indeed, it is eminently plausible that a chief motivation behind such patronage is to entrench managers, negating the block shareholders' takeover threat, and thereby harming overall corporate welfare. ${ }^{125}$ If this view is correct, then shareholder favoritism is undeniably problematic, and may warrant prohibition.

Nevertheless, even if one were sympathetic to the prohibitionist argument in theory, ${ }^{126}$ implementing it in practice can be at best difficult, and at worst haphazard and counterproductive. Perhaps the most immediate practical problem (noted numerous times above) stems from the multiplicity of mechanisms that managers can employ to play favorites, including outright transfers, capital market transactions, business dealings, diversion of corporate opportunities, selective information disclosure, and so forth. Each of these devices individually is likely to play an important role in patronage, and collectively they are likely to be perceived as substitutes of one another in the eyes of a manager.

Piecemeal prohibitions against one form of payment or another, then, are apt to have little overall effect beyond shifting activity toward other forms of patronage. For example, the stringent prohibitions on making outright cash distributions to a block shareholder might well cause managers instead to seek a one-sided contractual relationship with or shift their business activities to the shareholder. While this regulatory cat-andmouse game is a difficult and costly one to play in its own right, the inefficiencies it presents are not limited to the costs of designing new regulations and devising end runs around them. Indeed, many substitute mechanisms for playing favorites-those that are least susceptible to effective regulation-impose additional inefficiencies themselves. While direct cash distributions result in a dollar-for-dollar transfer in value, for instance, patronage through transferring corporate opportunities to a favored shareholder can decrease efficiency by channeling projects to a higher-cost producer.

125. See supra note 9 (citing commentators that view defensive tactics that simply close off the possibility of a hostile takeover as inimical to shareholder welfare).

126. We question whether, as a theoretical matter, prohibitions against managerial favoritism of shareholders in fact increase overall shareholder welfare. See infra Part III. 
Regulators, of course, might attempt to respond to this problem by categorically tightening all prohibitions of favoritism. Indeed, the SEC's Regulation FD might represent such an attempt for informational patronage. But even here, it seems unlikely that regulating entities will be able to capture the entire domain of circumstances where favoritism can exist, or alternatively that highly motivated managers cannot eventually find a way to skirt the prohibition, perhaps by some ingenious innovation that introduces even more technical inefficiencies.

Another problem with such across-the-board regulation is the danger of over-inclusiveness. In many circumstances, a number of legitimate justifications exist for managers' business decisions, even if (on first blush) they resemble in-kind favoritism. Indeed, a manager may hire a shareholder as a consultant to the firm because the shareholder in fact holds valuable expertise. Alternatively, a shareholder may have good information on the firm, and might therefore serve as the lowest-cost source of capital for a loan. Particularly for hard-to-value goods and services, courts often lack the ability to distinguish when the purpose of a particular act of largess represents favoritism or simple good sense.

Finally, as if the above impediments were insufficient, regulators seeking to prohibit shareholder favoritism across all possible circumstances face one additional hurdle. The present barriers to patronage span federal and state tax law, federal securities law, and state corporate law. Devising a cohesive system to address all instances of shareholder favoritism therefore requires some degree of coordination across these varying regulatory bodies-not all of which focus on shareholder welfare as their primary regulatory goal. Although not impossible in a theoretical sense, the necessity of harmonizing these various bodies of law presents a daunting challenge to even the most stout-hearted of regulators.

Such impediments have perhaps led courts and policymakers, at least in part, to resist across-the-board proscription, focusing on the most direct and obvious mechanisms for playing favorites, such as cash distributions, as the chief targets for scrutiny. Such a pattern seems all the more natural given that the more direct the benefit, the more transparent and verifiable it is to third parties. What this regulatory scheme has wrought, however, is a perforated legal landscape, rife with safe havens for managers willing to supply patronage to favored shareholders through less direct but often more costly methods. Thus, even if one were committed to the proposition that favoritism warrants abolition, it does not necessarily follow that instituting a series of piecemeal prohibitions can feasibly allay these concerns. Regulators may simply drive managers toward the less direct means of 
favoring shareholders, resulting in just as much opportunism but at a higher inefficiency cost to the detriment of all shareholders. An apparent conundrum therefore exists: Regulators who wish to ban favoritism completely must strengthen legal restrictions against not only direct but all indirect forms of selective wealth transfers to shareholders. Regulators, however, who seek to ban all forms of potential favoritism will almost certainly sweep too broadly, eliminating even value-increasing transactions between firms and shareholders. In the next Part, we attempt to provide a partial solution to this puzzle, arguing that regulators may wish to reassess whether permitting acts of patronage may have unappreciated, efficiencyenhancing effects (at least in certain situations).

\section{REASSESSING FAVORITISM}

Our discussion thus far has focused on the legal regulation of shareholder favoritism from an administrative-cost perspective. In other words, we have taken for granted the desirability of prohibition and have questioned whether such a goal is a practical feasibility. We now turn to our theoretical argument, which requires us to reverse logical course, presuming the feasibility of effective regulation and questioning whether the argument for prohibition is self-evident on its own terms. We argue that it is not and that, much to the contrary, allowing managers to play favorites may have an independent efficiency rationale that cuts to the very heart of a firm's incentive structure.

The kernel of our argument is simple. As noted in the Introduction, a legal regime that permitted favoritism for widely held firms would expose managers to an increased risk that outside investors would assemble a block of shares solely for the purpose of "holding up" the management, extracting some sort of payment in consideration for abandoning the takeover attempt. By paying off the block shareholder, then, management may be able to entrench itself, but only at the price of sharing the private benefits of control. Alternatively, management could attempt to deter the formation of a block (and thus the ensuing bribe) in the first instance, by committing to a governance structure that limits its own ability to appropriate firm value. So doing both increases the cost of forming a toehold, and credibly limits the size of the bribe that managers are willing to pay. We argue below that in many plausible circumstances, managers would prefer deterrence to acquiescence, and accordingly that permitting favoritism can work in the interests of all shareholders. 


\section{A. RECEIVED WISDOM}

As a prelude to our conceptual analysis, it is perhaps worthwhile to pause at this juncture to review what one might call the "received wisdom" about shareholder favoritism. Doing so will help to gain perspective both on our contribution and its relationship with the (admittedly vast) law-andeconomics literature on corporate governance.

Most economically motivated descriptions of the corporation (and ours is no exception) have at their core what might be called an "agency cost" account of the firm. This perspective emanates from a familiar observation that shareholders in publicly held corporations face a significant incentive problem in dealing with a company's managers. ${ }^{127}$ Particularly when shares are widely dispersed, no single shareholder has both the incentive and resources to monitor management closely. After all, a principal reason to employ managers in the first place is to allow numerous public shareholders to provide their capital but not their time or expertise to a business. ${ }^{128}$ This separation of ownership from control, in turn, provides managers with considerable discretion to make decisions that systematically benefit their own interests at the expense of rationally ignorant shareholders, either through shirking or outright appropriations of company value.

Such perverse managerial incentives can be disquieting for any number of reasons. From an economic perspective, however, acts of managerial self-interest are a concern principally because they are organizationally inefficient-that is, the benefits to self-serving managers are strictly less than the costs imposed on shareholders (along, perhaps, with other stakeholders), thereby causing aggregate company value to fall short of its potential. Rational shareholders, of course, can (at least in theory) anticipate downstream managerial misconduct and adjust their initial behavior accordingly, by either refusing to invest in the company or by investing only on highly discounted terms. ${ }^{129}$ But even so, this

127. See, e.g., Fama, supra note 1; Fama \& Jensen, supra note 1, at 304; Jensen \& Meckling, supra note 1 , at 308-10.

128. See adolf A. Berle, Jr. \& Gardiner C. Means, The Modern Corporation and PRIVATE PROPERTY (1932). Recently, economists have introduced evidence that large publicly-held corporations lacking significant blocks of shares are a relatively rare phenomenon in the world capital markets. Many firms outside the United States and the United Kingdom, in fact, are characterized by a controlling block shareholder comprised of either a controlling family or the state. See, e.g., La Porta et al., supra note 30 , at 471 . Our analysis, therefore, applies most directly only to the United States, the United Kingdom, and other markets where shareholders are dispersed.

129. For example, a well-documented lack of protections for minority investors against the opportunism of managers in Russia has led to extremely low asset valuations in that country. See Alan 
adjustment increases the cost faced by a corporation of raising outside capital, an impediment that causes many socially valuable business ventures to be passed up. Consequently, much scholarship within corporate law focuses on how legal rules, compensation schemes, ownership structures, and outside markets can each help mitigate the agency costs that dwell within the gulf between ownership and control.

One oft-proposed "Coasean" solution to this problem combines market forces and legal constraints. At the time a firm initially goes public, the firm's promoters have a strong incentive to make credible assurances that corporate management has a limited ability to self-deal. Indeed, so doing can reduce the firm's cost of raising capital in the securities market. Consequently, this argument contends, the entrepreneurs in control of the firm will find it attractive to implement contractual obligations and corporate governance structures that efficiently limit the ability of management to expropriate value from shareholders. ${ }^{130}$ If courts stood by reliably to enforce such self-restraints, this type of ex ante commitment becomes credible, and can significantly decrease the equity premium attributable to prospective managerial agency costs.

In practice, of course, the Coasean solution often falls far short of its theoretical promise. For starters, ex ante contracting is a costly and time consuming endeavor, requiring significant and detailed foresight about the future obstacles and opportunities a company may face. Entrepreneurs frequently lack the requisite ability to specify sufficiently detailed provisions to govern every possible future contingency. In such circumstances, an attempt to limit managerial discretion ex ante may backfire and stifle future corporate flexibility. In addition, even if such contractual foresight were possible, nothing guarantees that a court or other regulatory body, attempting to interpret the terms years after they were executed, would be able to decipher them accurately.

In light of these limitations, alternative means for aligning the incentives of managers and shareholders must play a greater role. Corporations scholars have therefore directed significant efforts toward specifying and formalizing such alternative mechanisms. For legal scholars, state corporate law and other forms of regulatory intervention have traditionally received significant attention. ${ }^{131}$ Most notably, fiduciary

Cullison, Merger Madness Hits Russia's Exporters, WALL ST. J., June 6, 2001, at A22 (reporting that low asset valuations are leading to a merger wave in Russia).

130. See, e.g., Jensen \& Meckling, supra note 1, at 305-07.

131. Indeed, reccntly economists have focused attention on the value of strong minority investor protections in explaining differences in financial development across countries. See Rafael La Porta, 
duties can work to restrict the ability of managers to expropriate corporate value selfishly. ${ }^{132}$ Whether managers attempt to extract value directly (through outright transfers of cash to themselves) or more indirectly (through, for example, shirking or conflicted transactions with the firm), the duties of loyalty and care can act as an effective deterrent. But regulatory approaches are not without their own limitations. The requirement that shareholders seeking to enforce the duty of loyalty must do so through a derivative suit imposes large procedural impediments to such suits-such as demand requirements, heightened pleading standards, and deference to independent litigation committees. ${ }^{133}$ While restricting the number of frivolous suits, such procedural hurdles potentially render mute numerous legitimate suits aimed at opportunistic managers. Moreover, even for those plaintiffs who can surpass the procedural obstacles, the contours of the substantive law they will face frequently lean toward management's corner, through either the protective business judgment rule or the well-known "cleansing" procedures through which directors can insulate themselves. ${ }^{134}$ As such, regulatory approaches alone are not likely to be a complete solution to agency cost problems.

Given these difficulties, numerous law and economics scholars have also championed market forces as a potentially important device for effecting managerial discipline. Managers who care about their future employment prospects in the labor market, for example, may limit the amount they expropriate. ${ }^{135}$ Managers may also work pursuant to employment contracts that provide for variable pay based on the firm's performance; similarly, managers may receive stock options tied to the value of the firm's stock. ${ }^{136}$ Product market competition may also reduce the rents within the corporation available for managers to purloin as private

Florencio Lopez-De-Silanes, \& Andrei Shleifer, Legal Determinants of External Finance, 52 J. FiN. 1131 (1997) (demonstrating link between investor protection and capital market activity).

132. See, e.g., REvisEd MODEL Bus. CORP. ACT $\$ 8.30$ (a) (1998) ("A director shall discharge his duties as a director, including the duties as a member of a committee ... in a manner he reasonably believes to be in the best interests of the corporation."). See also Robert Cooter \& Bradley J. Freedman, The Fiduciary Relationship: Its Economic Character and Legal Consequences, 66 N.Y.U. L. REv. 1045 (1991) (providing a law and economics analysis of the fiduciary duties); supra note 57 (describing the duty of loyalty).

133. See supra note 61 (discussing the demand requirement).

134. See supra note 57 (discussing ratification under Delaware state corporate law).

135. See Fama, supra note 1, at 305-06. Cf. Senbongi \& Harrington, supra note 5, at 305-06 (predicting that managers produce more quantity than necessary to maximize profits in imperfectly competitive industries as a means of increasing their reputation in the managerial labor market).

136. See Michael C. Jensen, Management Compensation and the Managerial Labor Market, $7 \mathrm{~J}$. ACCT. \& ECON. 3, 4-6 (1985); Michael C. Jensen \& Jerold L. Zimmerman, Eclipse of the Public Corporation, HaRv. Bus. Rev., Sept.-Oct. 1989, at 64-66. 
benefits of control. ${ }^{137}$ And shareholders may even attempt to rely on the business ethics of managers not to purloin too great a level of firm value. ${ }^{138}$

Of all these market-based approaches, however, the market for corporate control is one of the most oft-cited sources of discipline constraining managerial agency costs. Particularly when a company's outstanding shares are publicly traded and widely dispersed, a hostile takeover may become attractive when the overall performance of a manager results in anemic corporate value. Indeed, the worse a manager's performance becomes, the lower the company's share price will sink, and the more attractive a takeover becomes. Managers who slack or choose to divert corporate resources for their own individual purposes may therefore be the authors of their own demise.

Because of the unique role played by takeover markets in disciplining managers, most corporate law scholars agree that it is important to maintain the robustness and competitiveness of such markets. This attention is for good reason-managers may be able to take a number of actions that reduce the effectiveness of the takeover market. They may, for example, implement a poison pill, ${ }^{139}$ which forces a potential acquirer to first wage a proxy contest to takeover the board of directors before it may cancel the pill. ${ }^{140}$ In addition, managers may respond to the threat of a proxy contest through a classified board. Directors on a classified board typically hold their seats for overlapping terms of three or more years, ${ }^{141}$ forcing an acquirer to wait years before obtaining control over the board. To the extent that these (and other) maneuvers dilute and retard the market for corporate control, shareholders as a body lose.

137. See Harold Demsetz, The Structure of Ownership and the Theory of the Firm, 26 J.L. \& ECON. 375, 379 (1983). But see Jensen \& Meckling, supra note 1, at 330 ("[T]he existence of competition in product... markets will not eliminate the agency costs due to managerial control problems. ... If my competitors all incur agency costs equal to or greater than mine I will not be eliminated from the market by their competition.").

138. Many business schools, for example, require students to enroll in business ethics courses. See Richard Donkin, Business Ethics: The Rights and Wrongs, FIN. T1MEs, Oct. 9, 1997, at 4.

139. Although a wide variety of poison pills exist, all of them share a type of "scorched earth" feature: that is, once a change in control becomes likely, the pill provides attractive rights to outside parties that drastically reduce the value of the company (thereby rendering the takeover unprofitable). See generally Harold S. Bloomenthal \& Samuel WolfF, Securities \& Federal Corporate LAW $\S 25: 79$ (1998) (providing a description of poison pills).

140. Under so-called dead hand pills, even newly-elected boards of directors of the target corporation are unable to redeem the outstanding poison pills. See Jeffrey N. Gordon, "Just Say Never?" Poison Pills, Deadhand Pills, and Shareholder-Adopted By-Laws: An Essay for Warren Buffett, 19 CARDOZO L. REv. 511 (1997).

141. See Del. Code ANN. tit. 8, § 141(d) (1998); Model Bus. Corp. ACT $\$ 8.06$ (1979). 
Viewed in this light, it should not be surprising that shareholder favoritism is thought to constitute yet another device that impairs the takeover market. In particular, managers fearing a hostile takeover may seek to form a coalition with a block shareholder to ensure that shareholder's quiescence. Such coalitions can be helpful even when the block shareholder does not own sufficient shares for control, since the block shareholder's cooperation with management will increase the cost to other outside investors contemplating a hostile takeover. In the context of our earlier example, Acme management's alliance with Merit means that any third party acquirer would have to assemble a block larger than Merit's (since Merit strongly supports Acme management in return for management's favoritism). And, since Merit probably acquired its shares from the shareholders with the lowest reservation price for their shares, ${ }^{142}$ the remaining dispersed shareholders are likely to be even more reluctant to sell their shares, raising the cost to another outside investor yet again. ${ }^{143}$ Alternatively, the preexisting block shareholder itself may represent the most likely candidate to initiate a hostile takeover. A payoff may therefore reduce the value of pursuing a costly control contest to the block, redounding to the benefit of the incumbent managers.

Much of the received wisdom on shareholder favoritism maintains that opportunistic patronage works to entrench managers and reduce overall shareholder welfare. ${ }^{144}$ Indeed, selective payments to favored shareholders can represent a thinly veiled quid pro quo for the block shareholders' ongoing passivity. Acme's managers, for example, may desire to appropriate significant private benefits from the firm, perhaps in the form of higher wages, greater perks, or interested transactions between the managers and the firm. If left unaddressed, the very existence of Merit as a potential acquirer clearly constrains management's ability to appropriate such benefits. Indeed, as value appropriation increases, the trading price of the firm's shares will drop, making an acquisition of the firm a more credible threat. ${ }^{145}$ By assembling a toehold, block shareholders like Merit put themselves in an even better position to engineer such a takeover, since

142. Although this may sound peculiar on first blush, shareholders can have differential proclivities to sell because of different tax status, expectations of firm value, and the like.

143. For a discussion of the rationale behind an upward sloping supply curve, see infra text accompanying notes $171-74$.

144. See Rock, supra note 82 (providing examples of "bad" relational investing where the outside large shareholder uses its influence to obtain private benefits).

145. Alternatively, large block shareholders may find it worthwhile to employ substitute mechanisms of disciplining managers including a proxy control contest as well as the initiation of a fiduciary duty derivative lawsuit. 
they have already traveled part of the way there by virtue of their existing ownership stake. Obtaining the support of block shareholders, then, is of preeminent importance to Acme management, for it both nullifies their takeover threat, and it further raises the cost of assembling an independent control block for other outside investors. Managers therefore may enjoy an increased ability to appropriate private benefits in the presence of such payments.

While Acme's management has obvious incentives to cut a deal with Merit, Merit itself may stand to gain from one as well. ${ }^{146}$ Indeed, payments of cash (and to a lesser extent, property or other business activities) provide a fixed and certain benefit for the recipient shareholder. In deciding to support management in return for the payment, the shareholder can avoid bearing the high costs and risks implicit in attempting to make good on a takeover threat. Moreover, the ease with which cash distributions are valued (versus other sorts of favoritism) may further enhance this benefit. Consequently, it is perhaps easy to understand why selective payments are so attractive to managers and large block shareholders. Likewise, it is easy to understand why courts and legislatures have viewed such side payments so critically.

Notably, a small number of legal scholars have questioned whether this common wisdom is correct, positing (as do we) that shareholders as a group can benefit from such transfers. In the context of an active takeover contest, for example, Jonathan Macey and Fred McChesney have argued that paying greenmail to a potential acquiring shareholder may help compensate the shareholder for its initial investigation in determining a worthwhile takeover target. ${ }^{147}$ The prospect of receiving greenmail, therefore, may help induce value-increasing takeovers. While this explanation is a good one for rationalizing patronage in the immediate context of a takeover contest, it has less explanatory power in situations where takeovers are not a looming threat.

146. Merit may use not only the threat of a takeover but also the threat of initiating a shareholder issue proposal or a proxy control contest among other actions to extract rents from managers. See generally Gordon, supra note 105, at 376-84 (providing a discussion of how shareholders may seek to extract their own private gains when given the power to pursue shareholder initiatives). Significantly, the larger the size of Merit's block of shares, the more votes Merit will supply in favor of its shareholder initiative and the more likely other shareholders may view Merit's proxy issue proposal or control contest as legitimate (to the extent Merit will have a greater incentive to maximize share value the greater the fraction of shares in Merit's hands).

147. See, e.g., Macey \& McChesney, supra note 11. Alternatively, managers may use greenmail to payoff an initial bidder, giving other higher valuing bidders the necessary time to put forth their own bids. See id. 
Outside of the takeover context, Ian Ayres and Peter Cramton have highlighted the possibility that block shareholders may also become excellent monitors. ${ }^{148}$ In particular, block shareholders that maintain a long-term relationship with the firm may work to monitor management and help implement implicit contracts that would not otherwise be possible. ${ }^{149}$ Since the benefit from such activities accrues to all shareholders, however, it is unlikely that a single investor will have sufficient incentives to form a block of shares in order to monitor. The prospect of receiving payments from the firm may, Ayres and Cramton note, help induce outside investors to form such relational blocks of shares. ${ }^{150}$

While Ayres and Cramton's account also seems plausible, it suffers from one potentially significant drawback: nothing in their theory precludes the possibility that a block shareholder, once occupying that position, will find that collecting side payments from opportunistic management is more lucrative than monitoring. ${ }^{151}$ Even under Ayres and Cramton's view, then, regulators may still wish to prohibit acts of patronage when done solely to nullify a takeover threat and induce the block shareholder to abstain from monitoring. ${ }^{152}$ Discerning the "noble" acts of patronage from those that are merely "opportunistic" presents its own set of substantial problems.

Thus, while other commentators have made specific arguments that selective payments to shareholders may have benefits that counteract the costs of opportunism, we take a different approach. In short, we embrace

148. See Ian Ayres \& Peter Cramton, Relational Investing and Agency Theory, 15 CARDozo L. REV. 1033, 1062-63 (1994) (arguing that block shareholders with a long-term relation with management may serve to monitor for agency problems and help implement optimal implicit contractual arrangements). See also Roberta Romano, Corporate Law and Corporate Governance, 5 INDUS. \& CORP. CHANGE 277, 298-303 (1996) (summarizing various theories of relational investing); Andrei Shleifer \& Robert W. Vishny, Large Shareholders and Corporate Control, 94 J. PoL. ECON. 461 (1986) (noting that largc block shareholders have greater incentives than small dispersed shareholders to monitor managers for agency problems).

149. In addition, a block shareholder's repeat relationship with a firm's management allows for various implicit contractual devices to reward and punish managers. For example, not all instances of opportunism are verifiable in a court. Nevertheless, a block shareholder with a high level of monitoring may observe such violations and condition their support of management on controlling the level of such violations. See Ayres \& Cramton, supra note 148, at 1062-63.

150. See id. at 1051. One of the authors has made the argument that firms may use selective disclosures as an inducement to outside investors to form blocks of shares that work to monitor management, to the benefit of all shareholders. See Choi, supra note 110. In contrast, Ian Ayres and Peter Cramton also remark that: "The occasions in which incumbent management have subsidized the creation of a relational owner have included a number of entrenching maneuvers. Therefore, it is unsurprising to find that such friendly preferred placements have often lead to reductions in the value of common stock." Ayres \& Cramton, supra note 148, at 1051.

151. And Ayres and Cramton note as much. See Ayres \& Cramton, Supra note 148, at 1051.

152. This paper later questions this view of regulation. See supra Part III. 
opportunism-or at least the credible threat of it-on its own terms. In many circumstances, we argue, regulators in fact may wish to ignore motivation entirely, and simply allow unimpeded favoritism for two reasons.

First, as we argued in Part II, even if patronage were anathema to corporate welfare, regulators would be foolish to focus their sights solely on individual acts without also considering substitute mechanisms available to managers intent on transferring value to a favored shareholder. ${ }^{153}$ At the very least, the presence of such substitute mechanisms renders questionable the efficacy of prohibitions against direct selective payments. In fact, if anything, the effort spent by managers concocting substitute mechanisms and the added distortions they introduce represent additional inefficiencies and costs of overinclusiveness that might reduce overall corporate welfare even further. Moreover, because patronage agreements are likely to be implicit and difficult to detect, it is doubtful that courts would be able to detect and sanction them with great reliability.

Second (and more importantly), we submit that judging shareholder favoritism only in light of ex post effects misses an important piece of the puzzle, particularly for advocates of the takeover market. In the subsections below, we offer a somewhat more general argument that regulators do not need to distinguish opportunistic driven forms of shareholder favoritism. Opportunistically driven payments to block shareholders may in fact work to increase overall corporate welfare through deterrence. Even where an opportunistic payment completely eliminates the possibility of a takeover, a judicial policy of permitting such payments may make shareholders even better off from an ex ante perspective. In

153. In the context of greenmail, Ronald Gilson notes one objection against potential greenmail prohibitions is that "elever" lawyers and investment bankers may devise equivalent methods of indirectly providing greenmail. Gilson, supra note 12, at 350-51. Gilson responds that the "substance of a greenmail transaction is far less malleable than its form" and thus despite different possible forms, courts should have the ability to identify greenmail "equivalent" transactions. Id. Gilson's analysis, however, ignores the problem with the selection of a form of greenmail payment that also may have legitimate uses. In such situations, courts may have difficulty untangling whether in fact the particular transactional form is being used for greenmail or for a legitimate use. Particularly where thin markets exist and whether the shareholder recipient of a payment is in fact receiving a premium is difficult to ascertain, courts may need to expend large amounts of resources in making a decision. Moreovcr, from the perspective of managers and large shareholders, forms that provide the most "cover" against courts recognizing the true nature of the transaction also may generate the most inefficiency. As discussed in Part II, a straight cash payment from the firm to a particular shareholder is the most efficient means of transferring value. Once a firm shifts toward hiring the shareholder for a job to which the shareholder is ill-suited (among other indirect forms of payments), the firm incurs large additional costs for each dollar of value transferred to the shareholder. See supra Part II. 
such circumstances, regulators may wish to rethink their opposition to shareholder patronage.

\section{B. A NEW THEORY OF PAYMENTS TO SHAREHOLDERS}

In this section, we turn to a more formal presentation of the conceptual portion of our argument, developing a simple game-theoretic model to study the strategic interaction between rational managers and rational potential block shareholders. ${ }^{154}$ Using this model, we demonstrate how giving managers the ability to make selective bribes to shareholders may, ironically, provide managers incentives to take value-maximizing actions and choose efficient governance mechanisms, in order to deter outside investors from building blocks solely for the purpose of extracting side payments. Consequently, we show, permitting favoritism can benefit even those shareholders who receive no patronage.

\section{Basic Framework}

In order to facilitate our analytical argument, we resuscitate the Acme Corporation hypothetical narrative developed in Part II. Recall that Acme is a publicly traded firm with I0 million shares of common stock outstanding, and 10 million well-diversified and highly dispersed shareholders, each owning a negligible fraction (in particular, one share) in the company. ${ }^{155}$ The relevant activities we consider take place over two periods, which we denote as "Period 1" and "Period 2." We further assume that future payoffs are discounted to present value at a uniform rate of $10 \%$-and thus, a one dollar payment in Period 2 is worth approximately ninety-one cents in Period 1. ${ }^{156}$ Our principal enterprise is to consider (i) how Acme's management team (denoted as player $M$ ) will choose to manage the company in light of a potential threat from an external block shareholder (denoted as player $B$ ); (ii) whether allowing "side deals" between $M$ and $B$ changes significantly the results of this interaction, and (iii) if so, what it means for other shareholders and corporate welfare as a whole.

154. We present only a simple, primarily numerical example to illustrate the intuition of our argument in this paper. In the companion technical piece we provide a more rigorous mathematical model of the impact of managers playing favorites with shareholders. See Choi \& Talley, supra note **.

155. So long as Acme's shareholders are all relatively dispersed, nothing turns on the one-shareper-shareholder assumption.

156. That is, $(\$ 1 / 1.10)=\$ 0.9090$. 
In order to proceed with our analysis, it is important for us to spell out precisely how the relevant parties are assumed to interact with one another in each period as summarized below:

Period 1: Management $(M)$ chooses the maximal level of private benefits $(X)$ to which it commits, and the outside investor $(B)$ decides whether to purchase a block of shares. $M$ may also be able to negotiate with $B$ for the payment of a "bribe" to $B$ in return for $B$ 's support of management (depending on whether such bribes are legally permitted). If no such deal is permitted or bargaining fails, $B$ may decide to purchase a controlling stake in the firm.

Period 2: Player $M$ (or $B$, if a takeover has occurred) chooses the amount of private benefits to expropriate, subject to the maximal commitment level that $M$ set in Period I. ${ }^{157}$

Of the two periods, Period 2 is easiest to describe. In this period, only one relevant decision is made: $M$ (or its successor ${ }^{158}$ ) decides how much of firm value it will appropriate in the form of private benefits of control. If Acme were managed in a completely selfless fashion, its expected fair market value at the end of Period 2 would be $\$ 1.1$ billion-or $\$ 110$ per share. When discounted back to present value at the beginning of Period 1 , then, a selflessly managed firm would have a total market value of $\$ 1$ billion-or $\$ 100$ per share. ${ }^{159}$ Nevertheless, $M$ may have some ability to appropriate a fraction of the firm's value in Period 2 for its own personal benefit. For convenience, we will sometimes denote this fractional value by the variable $x$. Thus, if $M$ appropriated say, $x=25 \%$ of Acme's firm value, Acme's Period 2 value would be $75 \%$ of $\$ 1.1$ billion, which has a present value (as of Period 1) of $\$ 750$ million-or seventy-five dollars per share. While hurting Acme's shareholders, such a diversion obviously helps $M$. Nevertheless, we shall assume that, in spite of $M$ 's personal gain, such actions are socially wasteful and that for each dollar of firm value

157. Here we abstract from the possibility that $B$ may actually enjoy synergy advantages that result in a higher overall valuation for the firm in $B$ 's hands than in $M$ 's hands. While certainly an important motivating force behind a takeover, we contend that synergy is simply orthogonal to our analysis. Whatever the value of a taking control to $B$, the prospects of also benefiting from extraction of rents from managers (when $B$ forms a toehold block as we discuss later in the paper) will increase the willingness of $B$ to purchase shares to form a block potentially opposed to management.

158. As it will turn out in our model, this party will always be $M$, who will have done "just enough" in the previous period to remain in control and fend off a hostile takeover.

159. At a $10 \%$ rate of discounting, the present value of $\$ 1.1$ billion is equal to $(\$ 1.1$ billion $) /(1+0.10)=\$ 1$ billion. 
appropriated, $M$ only benefits by forty cents. ${ }^{160}$ Consequently, by reducing Acme's present value by $\$ 250$ million, $M$ reaps a substantially smaller benefit, valued at $\$ 100$ million.

To focus squarely on the role of the market for corporate control as a disciplining device, we assume that $M$ 's decision about how much value to appropriate is "non-contractible," in that $M$ 's wages and other forms of compensation cannot be tailored to punish it for taking private benefits of control. All that constrains $M$ during this period is whether $M$ has previously (in Period 1) placed a credible constraint upon itself, effectively putting an upper bound on the amount of private benefits $M$ can appropriate (described at greater length below).

Assuming the parties anticipate these actions in Period 2 (all the while discounting them to present value in Period 1), we can now describe the first (and more interesting) period of the model. As noted above, we assume that in Period $1, M$ can commit to a maximal level of private benefits it can expropriate from the firm, which we will call $X$. And it is here where the presence of the outside investor, $B$, becomes important. For $B$ (as well as other investors), a failure by $M$ to make any such commitment toward abstinence is tantamount to a manifest intent to pillage the firm, decimating its future value. ${ }^{161}$ In Period 2, player $M$-assuming there are no constraints on its behavior-will choose simply to abscond with the entire firm. Anticipating this outcome, shareholders in Period 1 will discount the per-share price they are willing to pay for the firm (down to zero), thereby making it relatively easy for the outside investor to take over the firm by purchasing a majority stake, firing $M$ in the process. It is the fear of just such an acquisition that can (and, as it turns out, will) motivate $M$ to commit voluntarily to some maximal level of value appropriation, $X$. Although we later catalog a variety of means with which $M$ can so constrain itself in a credible fashion through various corporate governance

160. The choice of forty cents on the dollar (representing an efficiency of $40 \%$ ) is somewhat arbitrary. Nevertheless, the concept that $M$ will experience inefficiency in expropriating private benefits of control is not. To the extent fiduciary duties limit egregious acts of appropriation, for example, managers may need to hide their private benefits through perks and other nonmonetary means of transferring value that may not provide full dollar value to managers. The very act of hiding benefits may also require costly resource expenditures. Managers may also force the firm to deviate to less profitable activities to enhance their ability to appropriate value. For each dollar benefit that a manager receives from appropriation, firm value as a result may drop by more than one dollar. Moreover, the inefficiency is likely to increase the higher the levels of expropriation. The $40 \%$ average level of expropriation inefficiency assumption is therefore justified at least at high levels of expropriation. Overall corporate welfare therefore is maximized in the simple model when managers appropriate no private benefits.

161. See infra text accompanying note 226 (discussing the problem of credible commitment). 
devices, ${ }^{162}$ for current purposes we remain agnostic about the precise means for doing so. At the very least, $M$ may want to constrain itself just enough to keep the stock price relatively high, and by so doing make a takeover somewhat expensive to engineer.

Continuing with Period 1, once Acme's management has chosen the commitment level $X$, the outside investor decides whether to purchase shares with an eye toward a takeover. ${ }^{163}$ Although in the real world, such purchases can take place incrementally over time (through, say, a "creeping" tender offer), we shall simplify the analysis somewhat so that the outside investor must make all its purchases in at most two transactions-both occurring during Period $1:^{164}$ First, player $B$ can attempt to purchase a "toehold" position in the firm—one that falls short of taking a majority of shares, but nonetheless gives $B$ a credible threat to carry out a takeover. Second, $B$ can decide to increase its toehold position in the firm by purchasing whatever shares are still needed to take control of the firm, which we shall assume takes place at the $50 \%$ threshold. ${ }^{165}$

Permitting $B$ to purchase shares at two discrete points during Period 1 allows us to study how bargaining between $M$ and $B$ in the intervening time affects overall corporate welfare. It is the spoils of this bargain that we perceive to be the motivation behind both shareholder favoritism and ex ante deterrence. Indeed, if $M$ can make an opportunistic payment to secure the support of the toehold shareholder, then $M$ will find itself in a difficult position of choosing either (1) to form a coalition with the noncontrol block shareholder or (2) to commit to such selfless governance that the block shareholder never emerges despite the possibility of extracting rents from managers. As we shall demonstrate below, rather than share with a toehold

162. See infra Part III.C.2.

163. For now, we shall assume that only one outside investor possesses the financial resources to assemble something more than a trivial block of shares. We shall return to the possibility of numerous block shareholders shortly (a complication that reinforces our thesis rather than undercutting it). See infra text accompanying note 239.

164. This assumption is consistent with modern securities law, given that creeping tender offers must now be disclosed early on. See 15 U.S.C. $\$ 78 \mathrm{~m}$ (d) (2000).

165. Under state corporate law, shareholders elect the board of directors. DEL. CoDE ANN. tit. 8, $\S 211$ (b) (1998); MODEL BUS. CORP. ACT $\$ 8.03$ (d) (1979). The board of directors is given the power (unless otherwise specified in the corporate charter) to manage the business and affairs of the corporation. Del. CODE ANN. tit. 8, § 141(a); MODEL Bus. CORP. ACT § 8.01(b). Directors are elected through a plurality of the votes cast unless the corporate charter specifies cumulative voting. See DEL. CODE ANN. tit. 8, § 214; MODEL Bus. CORP. ACT $\$ 7.28$. 
block, $M$ will often prefer to commit to a lower level of private benefits (i.e., a lower $X$ ) so as to deter the formation of any toehold. ${ }^{166}$

With the basic framework in hand, our next task is to characterize how the equilibrium level of value appropriation changes in the absence and presence of bargaining, respectively. We discuss each of these cases in turn.

\section{The Takeover Deterrent in the Absence of Favoritism}

Consider first the constraints that the takeover market places on managerial opportunism in a world where bargaining for patronage by $B$ is prohibited. As noted above, managers who appropriate a large fraction of firm value can induce depressed share prices, thereby increasing the possibility of a hostile takeover. In particular, mismanagement by $M$ can make it profitable for $B$ to assemble a block of shares sufficient to obtain control over the corporation. Once in control, $B$ can replace $M$ with itself (or loyal agents), change firm policies, and (possibly) appropriate private benefits.

At the same time, however, even with obvious mismanagement, takeovers are costly to engineer. An outside potential acquirer faces not only legal requirements with respect to disclosure and the price paid, but may also suffer higher costs due to implementation of various antitakeover devices. And importantly, the acquirer must usually pay a "premium" to dislodge current shareholders from their interest-a premium that increases with the size of the block purchased. ${ }^{167}$

Such costs, in turn, provide managers with at least some leeway to appropriate private benefits without tempting a takeover. To represent this concept, we shall assume that $M$ can commit to a ceiling that limits its own ability to siphon corporate wealth (which we have called $X$ ). If $M$ is interested in maintaining its position, it will attempt to select this ceiling so that it "just" deters a takeover from occurring. When no bargaining is allowed, we shall define this critical ceiling as $X_{n b}$. Critically, if $X_{n b}$ is sufficiently small to drain all the profit incentives from an acquisition, $B$ will choose not to engage in one.

166. The alert reader will no doubt recognize that allowing for a two-stage purchase by $B$ is meaningful only insofar as bargaining is allowed between purchases. If no bargaining occurred, then nothing is added by explicitly permitting $B$ to make a two-stage purchase.

167. See supra text accompanying notes $217-25$. 
Just what value, then, will $M$ choose to set for $X_{n b}$ ? To investigate this question, we need to "solve" the game backwards starting with Period 2. ${ }^{168}$ Assume that $M$ has retained control of the company during Period 1, and is now considering how to manage the firm in the second stage. Here, the incentives are fairly straightforward: No longer facing the specter of a hostile acquisition, $M$ will have an incentive to divert as much value as possible (subject, of course, to the ceiling that $X_{n b}$ imposes). Consequently, then, the company will be worth $\left(1-X_{n b}\right) \times(\$ 1.1$ billion $)$ in Period 2, which has a discounted value of $\$\left(1-X_{n b}\right)$ billion dollars at the beginning of Period 1.

Now, consider $B$ 's position in Period 1, contemplating whether to engineer a hostile takeover of Acme. ${ }^{169}$ In deciding whether to construct a control block to takeover the firm, the outside investor will compare the benefits it receives for taking over the firm to the costs it must pay to construct a control block. As to the benefit, $B$ 's return is made up of two probability-weighted components. First, $B$ might be able to appropriate private benefits after a takeover-though it might do so only somewhat inefficiently: just like $M$, we assume that $B$ benefits by only some fraction of a dollar for each dollar's worth of firm value appropriated. ${ }^{170}$ But second, an acquiring $B$ might find that because it owns a large fraction of equity in the company, $B$ 's interests would be better served by maximizing the value of the firm and realizing a large capital gain over its investment.

As to the cost of amassing a control share of the firm, $B$ must be willing to offer a sufficiently large price to lure a strict majority (i.e., 5 million plus one) of Acme's shareholders to tender their shares. This can be a costly enterprise, and $B$ must take care to anticipate the "supply curve" of shares accurately. As with many applications in finance theory, ${ }^{171}$ we shall assume that it becomes increasingly costly on the margin for $B$ to amass larger and larger blocks of shares, and thus this supply curve is an upward sloping one. While this assumption is critical to our analysis, it can occur for many nonexclusive reasons. For example, shareholders may face

168. Our analysis uscs a rather conventional "backward induction" approach to characterize equilibrium behavior. That is, we begin with an analysis of the outcome of Period 2 of the model, and then discuss of the impact of that behavior on the parties' behavior in Period 1 .

169. As noted above, the absence of bargaining in this version of the analysis allows us to collapse the two-stage purchase by $B$ into a single one, implicitly assuming that $B$ purchases nothing at the first opportunity to purchase shares.

170. See infra notes $186-88$ and accompanying text.

171. For an extensive review of the evidence in support of upward sloping supply curves for shares, see Fried, supra note 36, at 434 n.65. 
a range of different tax consequences from the sale of their shares. ${ }^{172}$ Shareholders may also have a range of heterogeneous expectations as to firm value. ${ }^{173}$ And finally, as the outside investor assembles a sufficiently large block to make a takeover inevitable, the news may filter into the market, raising the expectation of shareholders in the market as to the value of their stock and thereby the secondary market price. ${ }^{174}$

We therefore posit that the outside investor faces an upward sloping supply curve for shares, and thus must pay a higher premium (over present value) the larger the block of shares it seeks to construct. In particular, to animate our analysis, we assume that the supply curve of shares has the following specific functional form: If the outside investor offers a price of $P$ dollars for each share, shareholders as a group will tender the quantity $Q(P)$ of their shares, where:

$$
Q(P)=(\mathrm{I} 0 \text { million }) \cdot\left(\mathrm{I} 1-\frac{\mathrm{I} 0 \cdot E(V)}{P}\right)
$$

The term $E(V)$ in this expression denotes the expectation that tendering shareholders have of the Period 2 per share value of the company should they tender. ${ }^{175}$ Importantly, this value may shift depending on whether the shareholder believes itself to be a "pivotal" shareholder in an acquisition-that is, if its share is required to cause a change in control to occur. In this case, a pivotal shareholder will realize that if it refuses to

172. For example, some shareholders may be nonprofit organizations and face no tax liability. Other shareholders may hold shares primarily purchased over one year in the past and therefore enjoy long-term capital gains preference on any appreciation in their shares. Still other shareholders may hold shares purchased within one year and face taxation at ordinary income rates for the appreciation in their shares. Shareholders who face differential tax liability upon the sale of their shares will require differential prices to induce them to sell, a trait that leads directly to an upward sloping supply curve for shares. See also David T. Brown \& Michael D. Ryngaert, The Determinants of Tendering Rates in Interfirm and Self-Tender Offers, 65 J. Bus. 529, 530 (1992) (reporting evidence that public shareholders with varying tax costs associatcd with tendering may result in some shareholdcrs accepting a tender offer while others decline such an offer).

173. See Stout, supra note 44, at 625-35 (1995) (advancing the theory that investors in the stock market may hold heterogeneous expectations as to share values).

174. To be sure, this generalization is not without caveats. For instance, investors may not have full information on the incentive of an outside investor in forming a block of shares. Often blocks of shares are assembled even when a takeover is not imminent. Under the Williams Act's 5\% rule, for example, outside investors may assemble a block consisting up to $5 \%$ of the outstanding stock without having to disclose their ownership. See supra notes 223-24 and accompanying text. The outside investor may therefore obtain the initial toehold block without having to pay a significant premium. On the other hand, the differential tax and heterogeneous expectations explanations for an increasing supply curve for shares may still result in the outside investor paying a premium even for blocks smaller than $5 \%$ of the outstanding shares. We concentrate on the tax rationale below.

175. More formally, $E(V)$ stands for the expected per share value of the corporation in Period 2. 
tender, the firm will continue under current management, while if it tenders, the firm will be governed by new management in a (possibly) different fashion. To the pivotal shareholder, therefore, $E(V)$ will represent the expected Period 2 value of the firm where a takeover does not occur (because it is the pivotal shareholder's potential decision not to take the offer that may scuttle the takeover). ${ }^{176}$

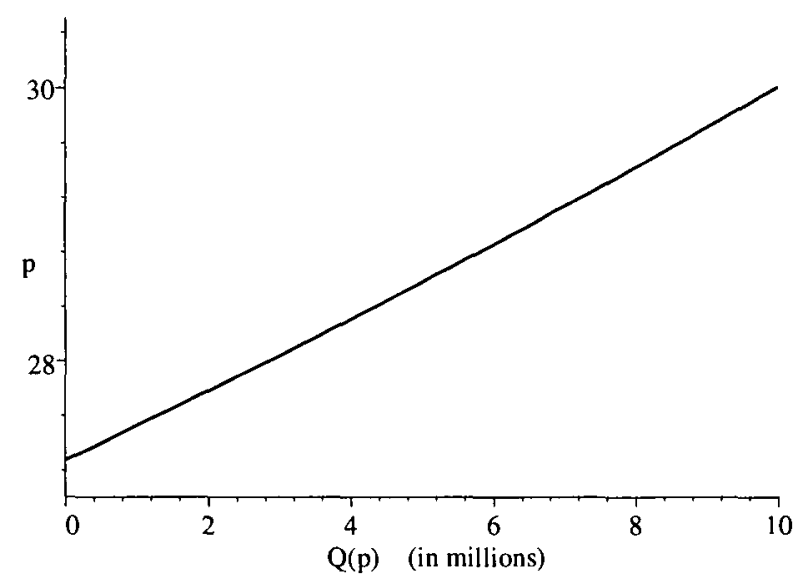

FIGURE 1: GRAPH OF THE SUPPLY CURVE

Figure 1 depicts the relationship between the size of the block and the price that the outside investor must pay for the block, under the assumption that $E(V)=\$ 30$ (giving a total firm a value of $\$ 300$ million in Period 2). Although seemingly arbitrary, the specific supply function for shares we use in fact represents the supply for shares that dispersed shareholders with varying tax rates would provide the purchasing outside investor. ${ }^{177}$ Consider a particular shareholder facing the decision whether to tender shares to $B$ in Period 1 or to hold on to the shares until Period 2. Shareholders that tender their shares in Period 1 face an immediate tax consequence on any gain, and then can invest their after-tax earnings at some outside interest rate (which we assume arbitrarily to be $10 \%$ ), which

176. We assume that a takeover requires strictly more than $50 \%$ of outstanding shares, and thus the shareholder that represents the 5,000,001st share of $B$ 's nascent control block realizes that its share is pivotal. Given the differential tax rate assumption behind the upward sloping supply curve for shares, the shareholder selling the 5,000,001 st will realize this pivotal position based on that shareholder's tax rate relative to other shareholders. In more realistic settings, the shareholder may not know this with certainty, of course. But even here, every shareholder may be able to make relatively accurate conjectures of their positions, so that something close to what is described in the text occurs.

177. See supra note 172 (describing various sources for differential tax rates among shareholders). The mathematical derivation of this supply curve can be found in Choi \& Talley, supra note **. 
is itself taxed in Period 2. All told, then, shareholders who do not tender retain the ability to avoid any taxes in Period 1 (and thereby enjoy tax-free buildup of their investment). Any shareholder with a positive marginal tax rate, therefore, will demand some premium be paid on top of the present value of the shares. By correlative reasoning, the higher the tax rate facing a shareholder, the greater the premium that shareholder will demand. Although we adopt this "tax" account for presentational ease, the intuition of our analysis applies regardless of the specific reason that supply function is upward sloping; what is critical is that the average cost of building a block of shares is increasing with the size of that block.

Our supply function implicitly assumes that B must pay the same price to all shareholders. ${ }^{178}$ Under this assumption, note from the figure that if $B$ offers thirty dollars per share in Period 1 (equal to the future expected per share value of the firm in Period 2), it can purchase all 10 million shares. Even shareholders facing relatively high tax rates will choose to sell their shares in Period 1 for thirty dollars in present value terms (and then face taxes on any gain) rather than wait until Period 2 to receive the same nominal thirty dollars (again facing taxes on the gain). ${ }^{179}$ Conversely, if $B$ offers any less than approximately $\$ 27.27$ (i.e., the present discounted value of thirty dollars in period 2 ), no one will tender. ${ }^{180}$ Finally, if $B$ offers (approximately) $\$ 28.58$ per share, then it can induce 5,000,001 shareholders to tender. ${ }^{181}$ This last figure is a critical threshold for $B$, since

178. This assumption is justified in part by the best price rule for tender offers under the Williams Act. See 15 U.S.C. $\$ 78 \mathrm{n}(\mathrm{d})(7)$ (2000).

179. Assume that a shareholder faces a $95 \%$ tax rate on any gains (and has a zero basis in the shares). If choosing not to tender, the shareholder will receive $\$ 30(E(V))$ for its shares in Period 2 and will be taxed at the $95 \%$ rate, leaving the shareholder with $\$ 1.50$ at the end of Period 2. Discounting back to Period 1, the shareholder will receive a net expected value of $\$ 1.36$. On the other hand, if the shareholder tenders in Period 1 for thirty dollars to $B$, the shareholder will receive $\$ 1.50$ in Period 1 (and is thus better off compared with the situation where the shareholder does not tender). In faet, for all tax rates up to $100 \%$, the shareholder is strictly better off from tendering where $B$ makes $E(V)$ the Period 1 bid price.

180. Assume that a shareholder faces a 5\% tax rate on any gains (and has a zero basis in the shares). If choosing not to tender, the shareholder will receive $\$ 30(E(V))$ for its shares in Period 2 and will be taxed at the $5 \%$ rate, leaving the shareholder with $\$ 28.50$ at the end of Period 2. Discounting back to Period 1, the shareholder will receive a net expected value of $\$ 25.909$. On the other hand, if the shareholder tenders the shares in Period 1 for $\$ 27.27$ to $B$, the shareholder will receive $\$ 25.907$ after tax in Period 1 (and is thus worse off compared with the situation where the shareholder does not tender). In fact, for all tax rates down to $0 \%$, the shareholder is strictly better off choosing not to tender where $B$ makes $\$ 27.27$ (equal to $E(V) / 1.1$ ) the Period 1 bid price.

181. This last number (and the specific supply function for shares used in the paper) depends on the assumption that Acme's shareholders are arrayed uniformly in their tax rates from $0 \%$ to $100 \%$. As with the other specific assumptions used to generate the paper's example, our analysis does not depend on this assumption. The key point is that shareholders may differ in their tax rate and thus face varying preferences between tendering today compared with staying invested in the firm's shares into the future. 
it is the least costly manner in which to engineer a takeover; purchasing a larger stake would not only require $B$ to raise the price paid to the additional shareholders, but since $B$ cannot determine who is the highest versus the lowest valuer among existing shareholders, it would have to raise the offered price to all tendering shareholders. ${ }^{182}$ Engineering such a takeover would therefore cost $B$ (in this particular case) a total of $(\$ 28.58) \times(5,000,001)=\$ 142.9$ million. $^{183}$

Hence, for this particular example, player $B$ will find a takeover profitable when and only when the private payoff from such a purchase exceeds this cost. To determine the benefit side of this comparison, realize that $B$ gains in one of at least two possible ways from a successful purchase of a control block. First, $B$ may choose to operate the firm at full efficiency, maximizing the value of the firm for all shareholders (including $B)$. The firm value in Period 2 where $B$ successfully engages in a takeover and pursues a strategy of maximizing firm value will be $E(V)=\$ 1.1$ billion. Because $B$ owns a little over $50 \%$ of the outstanding stock, $B$ will receive an expected benefit of $\$ 550$ million in Period 2 (equal to $\$ 500$ million in Period 1 dollars).

Alternatively, $B$ may choose to use its control to expropriate private benefits from the firm. As with the managers, $B$ will suffer some inefficiency in engaging in expropriation. ${ }^{184}$ Unlike the managers, however, $B$ suffers an additional cost from expropriation of value. The more value $B$ expropriates, the lower the value of $B$ 's own shares of common stock in the firm. In fact, only where $B$ 's efficiency at expropriation exceeds $50 \%$ will $B$ prefer extracting private benefits compared to the first strategy of maximizing overall firm welfare. For example, $B$ may enjoy the ability to capture sixty cents for every dollar taken as private benefits. In this situation, for each dollar $B$ expropriates, $B$ gains sixty cents directly and loses fifty cents from the loss in value of $B$ 's control block (as the firm value is reduced by one dollar, $B$ 's control block of a little over $50 \%$ of the shares drops in value by fifty cents accordingly). $B$ will therefore choose to expropriate the maximum possible level of

\footnotetext{
A different range of tax rates would result in a different breakpoint price at which 5,000,001 shareholders will choose to tender their shares to $B$. The supply equation also depends on the assumption that all shareholders share the same equilibrium expectation of the future value of the firm. For an explicit derivation, see Choi \& Talley, supra note **.

182. Moreover, under the Williams Act, to the extent a formal tender offer is initiated, the acquirer must pay all shareholders the highest price it offers any shareholder. See 15 U.S.C. $\$ 78 \mathrm{n}$ (d)(7) (2000).

183. More generally, we can calculate the offer price $P$ that $B$ must put forth to obtain a control block of shares: $P=(20 / 21) E(V)$.

184. See supra note 160 and accompanying text.
} 
private benefits, constrained only by the incumbent managers' initial selection of corporate governance devices to constrain private benefits, $X_{n b}{ }^{185}$

We assume that $B$ will not know its precise efficiency at expropriating private benefits until after $B$ in fact obtains control over the firm. ${ }^{186}$ To determine $B$ 's overall expected benefit from purchasing a control block, therefore, we need an assumption on the probability that $B$ will in fact have the ability to expropriate private benefits at an efficiency level greater than $50 \%$. We assume that $B$ 's efficiency at expropriation is distributed uniformly from 0 to $1 .{ }^{187}$ Under our assumptions, it turns out that $B$ will be a relatively efficient appropriator half of the time (while the other half of the time $B$ will find that maximizing firm value to be more profitable). Moreover, we assume that when $B$ in fact is able to expropriate at a greater than $50 \%$ efficiency level, $B$ 's expected efficiency is equal to $75 \% .^{188} B$ 's expected benefit from assembling a control block $\left(E\left(\pi_{B}\right)\right)$ is therefore equal to: ${ }^{189}$

$$
E\left(\pi_{B}\right)=(\$ 1.1 \text { billion })\left(0.5+0.125 X_{n b}\right)
$$

185. Suppose instead that for each dollar $B$ expropriates, $B$ gains forty cents directly (due to a $40 \%$ efficiency in extracting rents from the firm) and loses fifty cents from the loss in value of $B$ 's control block (as the firm value is reduced by one dollar, $B$ 's control block of a little over $50 \%$ of the shares drops in value by fifty cents accordingly). $B$ in this case will lose ten cents for every dollar appropriated as private benefits. $B$, accordingly, will choose to operate the firm at its maximal value without any private benefit expropriation.

186. $B$, for example, may not have full knowledge of the various confidential projects and opportunities within the firm from which $B$ may have some uncertain (and unknown at least prior to a takeover) degree of success in expropriating value.

187. The assumption of a uniform distribution simplifies our analysis but is unnecessary. All that matters is that the block shareholder expects with some positive probability (even if this probability is small) to be able to extract private benefits at an efficiency level greater than $50 \%$. Our qualitative analysis also changes little if the bloek shareholder knows the marginal value of the available private benefits at the beginning of the model (though the analysis becomes quantitatively a bit more complicated).

188. Given a uniform distribution, there is a $50 \%$ probability that $B$ 's efficiency of expropriation is $50 \%$ or under (and that therefore $B$-holding a control block of slightly more than $50 \%$ of Acme's shares-will not find expropriation of value profit-maximizing). Moreover, conditional on the efficiency of expropriation being larger than 50\%, the mean efficiency level given a uniform distribution is equal to $75 \%$. Once again, these assumptions are not critical to our analysis, but lend themselves to greater tractability.

189. More formally we can state that: $E\left(\pi_{n}\right)=$ Prob(efficiency $\left.\leq 0.5\right) \cdot(0.5 \cdot \$ 1.1$ billion $)+$ Prob(efficiency $>0.5) \cdot\left(0.5\left(1-X_{n b}\right)(\$ 1.1\right.$ billion $)+\left(0.75 \cdot X_{n b} \cdot \$ 1.1\right.$ billion $\left.)\right)$. Where $B$ 's efficiency of expropriation is $50 \%$ or under, $B$ gains more from maximizing the value of the $50 \%$ block rather than expropriating any value. Where $B$ 's efficiency of expropriation is more than $50 \%, B$ gains from expropriating value in an amount equal to the efficiency of expropriation (assumed equal to 75\%) times the level of expropriation $\left(X_{n b} . \$ 1.1\right.$ billion). In addition, $B$ suffers a loss on the $50 \%$ block of shares equal to the level of expropriation. Note that we assume that both Prob(efficiency $\leq 0.5)$ and Prob(efficiency $>0.5$ ) are equal to 0.5 (or $50 \%$ each). 
Note that as shareholders expect incumbent managers to expropriate a higher level of firm value in Period 2 (based on the managers' choice of a relatively high value of potential private benefits $X_{n b}$ through the corporate governance structure) the expected profit to $B$ from engaging in a takeover increases. As well, the cost of engineering a takeover will decline as the expectation of the pivotal shareholder of the value of the firm without such a takeover $E(V)$ is reduced (corresponding to a lower level of $X_{n b}$ ).

Given the above reasoning for $B$, consider now the ex ante incentives of Acme management, who will anticipate the possibility that $B$ will acquire the firm if it is managed too poorly. The more that $M$ ties its own hands through its choice of $X$, the lower the benefit to the outside investor from obtaining control. At the same time, the large cost of assembling a control block provides the manager with a bit of slack to appropriate at least some value without tempting a takeover. Managers will therefore set the level of private benefits just under the cost to an outside investor of assembling a control block. Put another way, $M$ will set $X_{n b}$ such that the outside potential block shareholder $B$ will find it unprofitable to assemble a control block.

Solving for $X_{n b}$ in the above example yields the condition that $M$ can forestall a takeover by $B$ whenever $X_{n b} \leq 3.67 \% .^{190}$ Put another way, managers who do not "self-constrain" to appropriating $3.67 \%$ of firm value or less will induce a hostile takeover with probability one. ${ }^{191}$ Given the alternatives, $M$ 's best option is to commit to a ceiling of $X_{n b}=3.67 \%$, so that $B$ finds it just barely unprofitable to pursue a takeover, and stays out of the market. Consequently, the Period 1 market price of Acme's shares is equal to $\$ 96.33$ per share. Managers in Period 2 then are able to extract a maximum total value of $\$ 16.15$ million (i.e., $3.67 \%$ of $\$ 1.1$ billion, multiplied by the managers' $40 \%$ efficiency of expropriation level), the Period 1 present value of which is $\$ 14.68$ million. We use the Period 1

190. B's Period 1 cost of assembling a control block is equal to $5,000,001 \cdot(20 / 21) \cdot E(V)$. The present value (in Period 1) of $B$ 's expected profit from assembling a control block is equal to $E\left(\pi_{B}\right) /(1.1)$ $=(\$ 1.1$ billion $)\left(0.5+0.125 X_{n b}\right) /(1.1)$. Using the fact that $E(V)=\left(I-X_{n b}\right)(\$ 1.1$ billion $) /(10$ million $)$, we can solve for the level of $X_{n b}$ that just makes $B$ indifferent about assembling a control block. With the specific numbers in the Acme example, $X_{n b}$ is equal to $3.67 \%$. Given this value of $X_{n b}$ note that the total cost of assembling a block of $5,000,001$ shares is equal to $\$ 504.59$ million. If a takeover does not occur, $B$ may sell the block of shares back into the market at the pre-takeover price of $\$ 96.33$ for proceeds of $\$ 481.65$ million. Thus, the net cost to $B$ is equal to $\$ 22.94$ million. Similarly, the net benefit of a takeover for $B$ (after subtracting the value of the 5,000,001 shares without a takeover) is equal to $\$ 22.94$ million. We assume that if $B$ is indifferent, $B$ will choose not to assemble the block.

191. We leave for later discussion the mechanisms by which a manager might do so. See infra Part III.C.2. 
private benefit level of $\$ 14.68$ million as the benchmark to compare with the outcome when shareholder favoritism is allowed.

The case just analyzed-where bargaining between $M$ and $B$ is not permitted-provides the baseline for our analysis in the next subsection of favoritism toward block shareholders. When we extend the model to allow bargaining, the manager's decision becomes somewhat more complex. Now $M$, in deciding on the level of private benefits to appropriate, will make this decision under the shadow of either a possible takeover, or the prospect of a "bribe" to an outside investor in order to discourage a takeover. As we demonstrate, the added possibility that $B$ forms a noncontrol toehold block simply for its "hold up" value in extracting a bribe can provide an additional ex ante deterrent effect on managers seeking to pilfer private benefits.

\section{Allowing Favoritism to Shareholders}

Imagine now that managers are free to bestow favoritism (e.g., pay bribes) on outside investors using corporate resources, in order to deter takeovers, and that such bribes are enforceable (in either judicial or extrajudicial venues). Through patronage, managers may be able to obtain the cooperation of a block of shares in supporting the managers' efforts at appropriating private benefits. Although the conventional wisdom is that such bribes decrease overall corporate welfare, this section makes the argument that from an ex ante standpoint, the ability to make bribes may actually be welfare enhancing.

As with the above case, we will continue to assume that $M$ can credibly commit to an "upper bound" on the fraction of firm value it can appropriate, or $X$; once management has made a decision to commit to this ceiling, it cannot change this commitment. ${ }^{192}$ The incentive effect of a possible takeover therefore occurs through $M$ 's expectations about how the outside investor will react to the ceiling that is chosen. Note also that without an actual takeover, extracting a bribe is the only reason $B$ would ever build a toehold block to begin with: for to do so requires paying a premium over present value, and if no takeover occurs, player $B$ cannot recoup this premium. ${ }^{193}$ Consequently, our analysis turns on a block

192. Although managers might try to represent (without any commitment) that they will appropriate a reduced amount, in the absence of a commitment, this representation is not credible. In such a case, investors that choose not to engineer an outright acquisition cannot expect any value of the company to remain.

193. On a related note, Arturo Bris presents evidence from a sample of tender offers in the United States from 1985 to 1998 that only $3.2 \%$ of the bidders had a prior toehold stake. See Arturo Bris, 
shareholder who is motivated solely by holding up management to extract a portion of $M$ 's private benefits. ${ }^{194}$ If $M$ acquiesces, it stays in power and might even benefit from an enhanced ability to extract private benefits from the firm; at the same time, however, $M$ also loses from having to share the spoils with another party. ${ }^{195}$ Management thus faces a choice. It may acquiesce to the appearance of an outside investor, implicitly agreeing to pay a portion of $M$ 's private benefits; in anticipation of this strategy, $M$ may then raise the commitment ceiling $X$ on the maximum level of private benefits $M$ can appropriate. Alternatively, however, $M$ might opt for the path of self-interested self-abnegation, committing a lower ceiling on private benefits in order to deter the formation of a toehold block altogether. Although the overall private benefits extracted will be lower, the manager may keep all of the benefits.

To analyze the impact of allowing favoritism, we now explicitly permit $B$ to make purchases at two points during Period 1. First, $B$ can purchase a toehold position in the firm, which falls short of the $50 \%$ threshold of control, but is large enough to make the threat to complete a

When Do Bidders Purchase a Toehold? (Sept. 2001), at http://faculty.som.yale.edu/ ab364/ toehold.PDF. Bris hypothesizes that assembling a toehold prior to a bid signals to the market the possibility of a takeover and thereby may lead to a run-up in the secondary market price, making the purchase of subsequent shares in the target more expensive for the bidder and decreasing the probability of a successful takeover. $I d$.

194. Note that we treat $B$ as a unified entity seeking to maximize the net worth of $B$. For many institutional investors, nevertheless, this assumption may not hold true. Instead, agency problems may exist within institutional investors between the ultimate providers of capital and the managers of the institution. See, e.g., Edward B. Rock, The Logic and (Uncertain) Significance of Institutional Shareholder Activism, 79 GEO. L. J. 445, 468-78 (1991). Money managers in charge of $B$ that seek to maximize their own personal wealth may, for example, choose to accept a smaller payoff (directed toward the money managers' own interests) from Acme's managers in return for B's support of the Acme's managers expropriation of private benefits. Money managers that are sufficiently indifferent to the welfare of $B$ 's ultimate owners may also choose not to have $B$ engage in opportunistic rent-seeking against Acme's managers to the extent the money managers bear at least the effort cost related to identifying a suitable target and assembling a toehold block of shares. We abstract from the issue of agency problems within institutional investors in this Article.

195. Implicitly, our analysis presumes that in any such division of benefits, $M$ simply diverts some portion of $M^{\prime}$ s private appropriations to $B$. As such, regardless of how such rents are divided, we presume for simplicity that so long as $M$ remains in control, the " $M-B$ team" still can only appropriate value at the $M$ 's $40 \%$ efficiency rate. Variations of the model might allow side payments to $B$ which exhibit either greater or lesser efficiency levels than those of $M$. While we do not explore such variations here, we conjecture their impact on our normative arugment to be relatively small. For an extreme example, if side payments could be directed to $B$ at $100 \%$ efficiency, then $M$ and $B$ would likely agree that $M$ would manage the firm efficiently, and direct all its value to $B$ (in return for some up-front cash payment from $B$ to $M$ ). While seemingly strange, such an equilibrium would actually constitute a first-best outcome from a social efficiency standpoint, and thus is consistent with our contention that permitting favoritism can be a socially desirable way to stem agency costs. (We thank Ed Kitch for providing this example.) 
takeover a credible one. After this initial purchase (if any) we allow for bargaining between $M$ and $B$. We suppose that the parties have equal bargaining power so that any gains from trade are divided into 50-50 portions. ${ }^{196}$ It is this payment that constitutes the bribe. Note that bargaining between managers and a toehold shareholder is allowed prior to the decision on the part of the toehold shareholder to continue on to a full control block. In the analysis of the toehold shareholder bargaining model, we once again proceed backwards through the stages in the model.

Except for a small variation, Period 2 of the model plays out much like before. Suppose $M$ has already set a fixed maximum level of private benefits, which we will now label $X_{b}$ (as opposed to $X_{n b}$ from before). And moreover, suppose that $M$ has retained control (through either deterrence or an effective bribe). If $B$ has been deterred entirely, $\mathrm{M}$ will appropriate and retain the entire fraction allowable, $X_{b}$. On the other hand, if $B$ has formed a toehold and formed a coalition, $M$ will still appropriate the full amount, rendering unto $B$ whatever payment is due per their agreement.

Working backwards to Period 1, things become more interesting. As noted above, prior to selecting an expropriation ceiling $X_{b}, M$ has to decide whether to opt for deterrence or accommodation of $B$. If $M$ opts for deterrence, it must obviously choose $X_{b}$ sufficiently small to vitiate any gain to $B$ from either (a) taking over the firm or (b) purchasing a block and demanding patronage. We know from the above analysis that an outright takeover never occurs so long as $M$ commits to $X=X_{n b}=3.67 \%$ or less. It turns out, however, that when bargaining is allowed, simply deterring a takeover is insufficient. Indeed, even though such a ceiling would certainly deter $B$ from assembling a control block in a single transaction, $B$ has the magic of "sunk costs" on its side. 197 Explicitly, $B$ still has the option of

196. The gain from trade in this instance is the difference if any between (a) the expected private benefits that $\boldsymbol{M}$ can glean if retaining control; and (b) the expectcd benefits that a toehold shareholder $B$ can capture (ignoring any sunk purchases) from going through with a takeover. The results derived below persist so long as $M$ does not possess "too much" of the bargaining power. See Choi \& Talley, supra note $* *$.

197. Sunk costs are expenditures that the outside investor is unable to recover once made. Of course, to the extent another potential acquirer exists, the outside investor may be able to resell its toehold block to the other acquirer at a premium (and thus take the loss of such a premium as part of the opportunity cost of undertaking a takeover). Nevertheless, in the absence of a readily identifiable buyer, the outside investor will find it difficult to liquidate the minority, noncontrol toehold block without suffering a loss (or experiencing delay). For a recent example, see Cassell Bryan-Low, Priceline.com Founder Jay Walker Sells Stock at Bargain Price, WALL ST. J., Aug 22, 2001, at C11 (reporting that Priceline.com founder Jay Walker sold most of his remaining minority block of shares to Cheung Kong and Hutchison Whampoa for $\$ 4.37$ for share when the secondary market price equaled $\$ 6.35$ per share). 
purchasing a tiny fraction of Acme (e.g., one share) so that the prospective gains from a takeover are barely positive, disregarding the now-sunk costs it took to purchase the toehold. By so doing, $B$ can become a credible negotiator with $M$, and $B$ 's share of the bargaining pie might be large enough to offset the cost of assembling the toehold.

Applying this reasoning to the instant example exposes the folly of selecting the expropriation ceiling $X_{b}$ equal to $X_{n b}$ (that is, the equilibrium value of $X$ when no bargaining is allowed). Indeed, if $M$ were to do so, it would-by definition-make the immediate costs of a takeover for $B$ (with no toehold) exactly balance the present value of the benefits (see Figure 2 below). ${ }^{198}$

\section{FIGURE 2: $B$ 'S DECISION TO ASSEMBLE A CONTROL BLOCK}

$$
\text { When } X_{b}=X_{n b}=3.67 \%
$$

\section{Net Benefit}

$\$ 22.94$ million $\underline{\text { Net Cost }}$

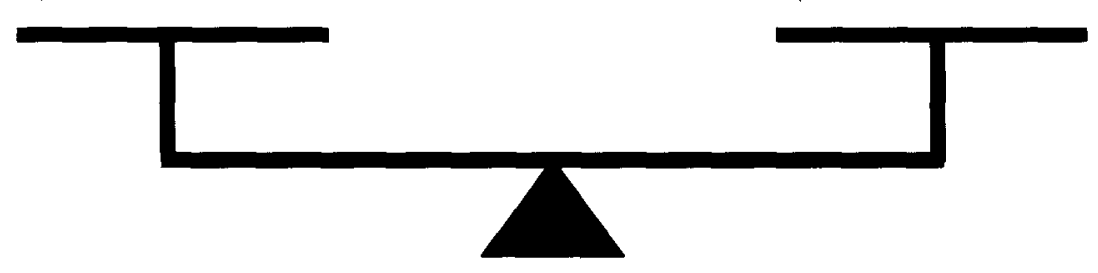

Now suppose in contrast that $B$ purchases a single share of Acme (for \$96.33). ${ }^{199}$ With the ownership of this single share, $B$ now faces a lower incremental cost of assembling a full control block. In particular, the incremental cost of assembling a full control block is now less than prior to the purchase of the single share (since $B$ now only needs to purchase $5,000,000$ shares to obtain control). Holding the single share, $B$ 's calculus

198. For a derivation of the numbers in Figure 2 see supra note 190 (calculating the maximum level of $X_{n b}$ where managers still deter an outright takeover given a prohibition against side payments to shareholders).

199. We assume that the shareholder that sells the single share to $B$ in Period 1 does so at a price equal to the expected per share value of the firm in Period 1. The price of a $\$ 96.33$ per share depends on managers expropriating $\$ 3.67$ per share of private benefits from the firm (corresponding to $X_{n b}$ $=3.67 \%$ ). Where, of course, managers choose to expropriate a lower amount to deter the formation of toehold blocks-as we discuss in this Article-the expected per share value will be correspondingly higher. 
on whether to assemble a control block when the maximum level of private benefits set by $M$ is equal to $X_{n b}$ now is fundamentally altered. Treating the cost of the single share as sunk, in making the second purchase, $B$ will consider a takeover as providing a net profit equal to $B$ 's reduced cost to assemble a control block. This single share purchase tips the balance for $B$ in favor of going forward with an outright acquisition, and thereby gives $B$ credible bargaining power against $M$ (see Figure 3 below). ${ }^{200}$

\section{Figure 3: IMPACT OF A TOEHOLD OF 1 SHARE}

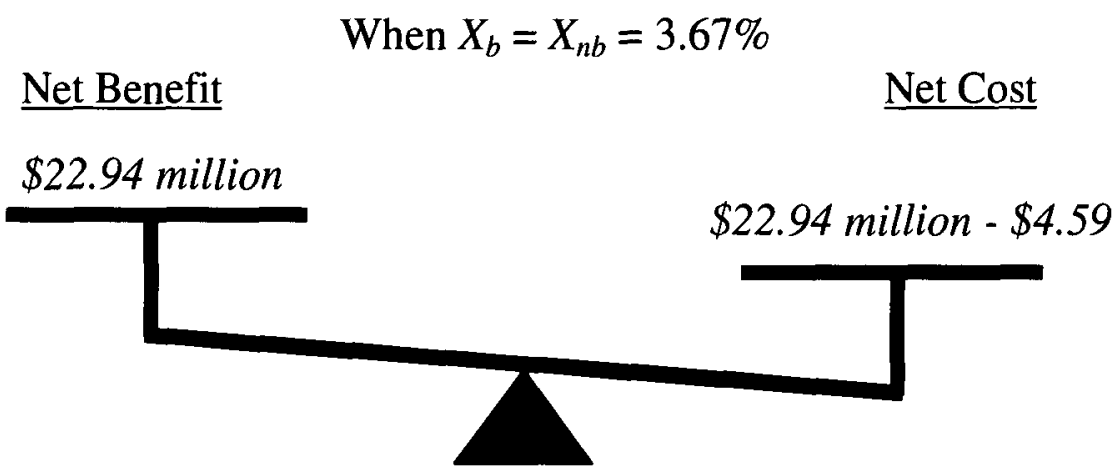

Armed with a bona fide takeover threat, $B$ can now attempt to extract a significant portion of $M$ 's $\$ 14.68$ million worth of private benefits. Assuming the bargaining surplus is split 50-50, $M$ will be forced to pay a bribe of approximately $\$ 7.34$ million in Period 1 dollars to keep $B$ from completing the takeover (leaving $\$ 7.34$ million for $M$ ). ${ }^{201}$ Note that where $B$ seeks only to establish a credible takeover threat to extract rents from the managers, $B$ will seek the smallest toehold block that gives it credibility.

200. Calculating this net profit requires some additional steps. First, $B$ 's net profit will equal the saved premium $B$ would otherwise have to pay on the one share if purchased as part of the control block transaction. Where $E(V)=\$ 96.33$, the Article's assumed supply curve for shares requires an offer price of $\$ 100.92$ for $B$ to purchase $5,000,001$ shares. Because shares are valuable even without a takeover, the net saved premium will equal the amount above the no-takeover value of the one share that $B$ no longer must expend to form a control block. Thus, $B$ 's net profit from proceeding to a takeover (given a toehold of I share) will equal $\$ 100.92$ (the premium price for the I share given a takeover) - $\$ 96.33$ (the value of the 1 share without a takeover $)=\$ 4.59$.

201. To see this, note that the bargaining range is the interval between ninety-six dollars (constituting the present value of $B$ 's gain from going forward with a takeover) on the lower end, and $\$ 33.61$ million (constituting the present value of $M$ 's benefit from appropriating $3.67 \%$ of firm value in Period 2) on the upper end. Splitting this bargaining range in half yields $B$ 's share. 
Purchasing a larger toehold simply raises $B^{\prime}$ 's cost without increasing its credibility.

The specter of paying off $B$ obviously reduces $M$ 's private benefits of control. Thus, if $M$ wished to avoid having to split the rents, $M$ would have to choose an even smaller value for $X_{b}$-sufficiently small that $B$ will find it unprofitable to form a toehold block from which to generate credibility in negotiating with $M .^{202}$

As it turns out in the Acme example, in order to deter $B$ from ever buying a toehold in the firm, $M$ would have to choose $X_{b}=2.12 \%$, more than 1.5 percentage points lower than $X_{n b}$. Note that at $X_{b}=2.12 \%$, the Period 1 value of each share without a takeover is equal to $\$ 97.88 .{ }^{203}$ The price, on the other hand, that $B$ must pay to acquire 5,000,001 shares (given the upward sloping supply function discussed above) is equal to $\$ 102.54$ per shares as measured in Period $1 .^{204}$ Consequently, the net unrecoverable cost from assembling a control block is thus equal to $\$ 23.3$ million. $^{205}$ Against this is the net expected Period 1 benefit that $B$ can anticipate from assembling a full control block of shares, which is equal to approximately $\$ 13.24$ million. $^{206}$ Obviously, an outright takeover (starting from zero shares) is not credible for an outside investor holding no shares (because the takeover would result in a net loss of $\$ 10.1$ million to $B$ ) (see Figure 4 below).

202. This value of $X_{b}$ clearly must be lower than the value of $X_{n b}$ derived in the "no patronage" case for two reasons. First, if the manager were to set the maximal level of private benefit expropriation above $X_{n b}$, we know from the prior section that $B$ will simply takeover the firm, leaving managers with zero profits. Second, as managers reduce the maximal level of private benefits below $X_{n b}$, the outside investor $B$ must form increasingly larger toeholds to generate a credible threat of engaging in a takeover. Lower levels of benefit expropriation translate into a lower potential profit for $B$ from engaging in a takeover. All other things being equal, $B$ will need to shift more of its costs of assembling a block to the initial "sunk" stage-through a larger toehold purchase-to present a credible subsequent threat of takeover to the incumbent managers. Where the cost of obtaining a toehold is increasing with the size of the toehold, $B$ may eventually find it not worthwhile to assemble the toehold (even given the prospects of rent extraction from managers) where managers have reduced their level of private benefits sufficiently.

203. The Period 1 value of the shares without a takeover is derived from $\left(1-X_{b}\right) \cdot(\$ 1.1$ billion) $/((10$ million $)(1.1))$.

204. The price per share to acquire $5,000,001$ shares was derived in note 183 and is equal to: $((20 / 21) E(V))$ where $E(V)$ is $((1-0.0212)(\$ 1.1$ billion $) /(10$ million $))$ or $\$ 107.67$. See supra note 183 . The per share acquisition price is therefore equal to $\$ 102.54$.

205. This is obtained from $5,000,001 \cdot(\$ 102.54-97.88)$.

206. The Period I value of the control block posttakeover is equal to $(\$ 1.1$ billion $)(0.5$ $+0.125(0.0212)) / 1.1$ or $\$ 502.65$ million. The Period 1 value pretakeover is equal to $5,000,001 . \$ 97.88$ or $\$ 489.40$ million. The expected benefit is thus equal to $\$ 502.7$ million minus $\$ 489.4$ million or $\$ 13.24$ million. 


\section{FIGURE 4: $B$ 's DECISION to ASSEMBLE A CONTROL BLOCK}

$$
\text { When } \mathrm{X}_{\mathrm{b}}=2.12 \%
$$

$\underline{\text { Net Cost }}$

$\$ 23.30$ million

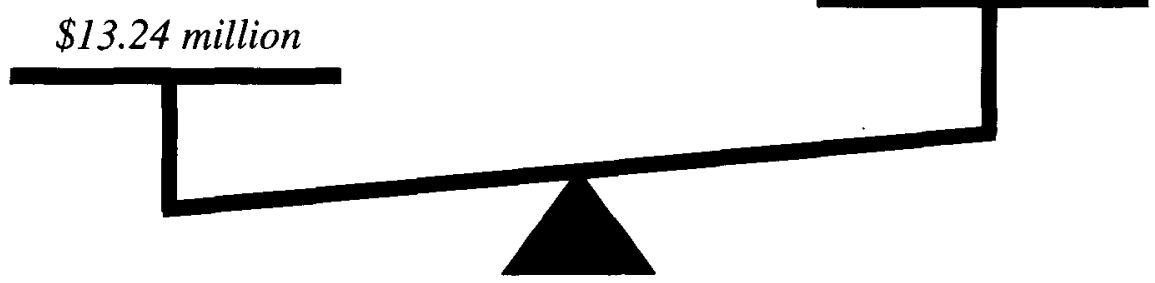

Assembling a noncontrol toehold may shift some of the unrecoverable cost of assembling a control block into sunk costs. It is no longer possible, however, for $B$ to become a credible bargainer after purchasing a single share. Because $B$ starts from a net loss of $\$ 10.1$ million from engaging in a takeover, $B$ will have to assemble a toehold of sufficient size to reduce $B$ 's incremental cost to constructing a control block by least $\$ 10$.I million (corresponding to a toehold of $21.6 \%$ of the outstanding shares) to generate a credible takeover threat. ${ }^{207}$

In deciding whether such a large toehold is worthwhile, $B$ will compare the costs of assembling the $21.6 \%$ toehold against the size of the bribe that $B$ can hope to extract. As to the latter, when $X_{b}$ is equal to $2.12 \%$ and managers extract rents with a $40 \%$ efficiency (as assumed in the Acme example), the Period 1 present value of private benefits is equal to $\$ 8.48$ million. ${ }^{208}$ Splitting this rent in half gives $B$ an expected share of $\$ 4.24$ million. As to the net cost of assembling the toehold, the required price for the toehold shares is equal to the price necessary to acquire a block of size $21.6 \%$ of the shares, and not the full 5,000,001 necessary for a control

207. If $B$ assembles a toehold of $2,160,249$ (corresponding to $21.6 \%$ of the shares of Acme) then $B$ will need to purchase an additional $2,839,752$ shares to form a control block. Following the assumed supply curve for shares, $B$ must expend $\$ 102.54$ per share (when $X_{b}=2.12 \%$ ) to purchase the remaining shares required for control. $B$ 's total incremental net cost will therefore equal $2,839,752 \times(\$ 102.54$ $-97.88)=\$ 13.23$ million, giving $B$ a credible threat of engaging in a takeover.

208. Where $X_{b}$ is equal to $2.12 \%$ the amount of rents extracted (measured from Period 1 ) is equal to $0.0212 \cdot(\$ 1.1$ billion $) /(1.1)$ or $\$ 21.2$ million. When managers suffer from only a $40 \%$ efficiency in extraction (due to fiduciary duty constraints among other things) this leaves only $\$ 8.48$ million of rents. 
block, leading to a lower per share price for the toehold in equilibrium. ${ }^{209}$ From the supply curve posited above, the price of such a purchase is therefore equal to $\$ 99.84$ per share, representing an unrecoverable $\$ 1.96$ premium over fair market value. The total sunk cost of assembling a toehold of $21.6 \%$ of the shares is thus equal to $\$ 4.24$ million, making $B$ just indifferent between assembling a credible toehold to extract rents from managers, and doing nothing at all (and we implicitly assume without loss of generality that indifference leads to intransigence). By reducing $X$ to $2.12 \%$, then, $M$ can ensure itself a level of private benefits of $\$ 8.48$ million, smaller than what is otherwise available, but one that need not be shared with $B$.

The path of deterrence, however, is not the only option available to incumbent management. Player $M$ might alternatively respond to player $B$ 's threat by deliberately inviting a coalition with $B$. While this seems counter-intuitive at first, note that at least theoretically, it could be in $M$ 's interests to do so if it allows $M$ to appropriate even more value than would otherwise be available under a strategy of deterrence. Under this view, a manager might set $X_{b}$ extremely high, knowing full well that it will induce a block shareholder to appear, but even after paying $B$ off, $M$ may have a significant portion left over to retain. Interestingly, however, analysis of this option yields the result that even if $M$ chooses accommodation, $X_{b}$ would still be optimally set equal to $3.67 \%$. Note that $X_{b}$ equals $X_{n b}$, the value of appropriation in the case where patronage is prohibited.

One might think on first blush that an accommodating manager might rationally go even higher still, content in the safety that a coalition with $B$ would bring. It turns out, however, that this strategy would not be in $M$ 's interests. While it would permit a higher level of private benefits to be split between $M$ and $B$, it simultaneously increases the profits that $B$ can expect from an outright takeover (in which $M$ is displaced). ${ }^{210}$ Because of this latter factor, $B$ 's "threat point" becomes more and more demanding as $X$ increases above $X_{n b}$, and $M$ must fully compensate $B$ for these foregone takeover profits, leaving an even smaller portion of the surplus available for $M{ }^{211}$ For example, if $M$ raises the level of private benefits one dollar beyond those benefits extracted with $X_{n b}$ then potentially forty cents (given

209. Note that since a bribe forestalls any takeover, no one expects an outright takeover to occur, and the market values the company as if current management will stay in power with certainty.

210. Where managers select $X_{n b}$ then $B$ is just indifferent about engaging in a takeover (and expects zero profits from doing so).

211. More formally, we adopt the notion of bargaining to split the surplus from an agreement first put forth in John F. Nash, Jr., The Bargaining Problem, 18 EconOMETRICA 155 (1950). 
$M$ 's $40 \%$ inefficiency of extraction) of additional benefits are available to split between $M$ and $B$. $B$, however, will now enjoy a possible profit of fifty cents from engaging in a takeover and maximizing firm value (given a $50 \%$ control block) and will demand at least fifty cents compensation (if not more $)^{212}$ from $M$ for entering into a coalition with $M$. $M$ therefore must not only give the entire forty cents additional private benefit surplus to $B$ but also an additional ten cents. Raising the level of private benefits past $X_{n b}$ (where $B$ receives a zero profit from engaging in a takeover) therefore leaves managers worse off. ${ }^{213}$

It therefore turns out that a manager in our model seeking to accommodate entry would set the maximal level of private benefits $X_{b}$ equal to $X_{n b}$ (or $3.67 \%$ in the Acme example). In response, player $B$ would purchase a single share, and would extract a bribe of approximately $\$ 7.34$ million from $M .^{214}$ After accounting for this side payment, $M$ 's expected payoff from forming a coalition with $B$ would be $\$(14.68$ million -7.34 million) equal to $\$ 7.34$ million.

Three aspects of these calculations described above deserve special attention. First, and most important, note that the net value retained by $M$ under a strategy of accommodation ( $\$ 7.34$ million) is strictly less than that yielded from a strategy of deterrence ( $\$ 8.48$ million). In other words, the

212. $B$ will require at least fifty cents in compensation because at a minimum $B$ will be able to increase the value of its block by fifty cents by eliminating all private benefits through a takeover. $B$ may also enjoy the ability to extract private benefits (to the extent the efficiency of $B$ 's expropriation exceeds the size of $B$ 's block of shares). See supra notes 184-89 and accompanying text. Managers seeking to pay off $B$, thus, must also compensate $B$ for $B$ 's own foregone potential private benefits of control.

213. Note that this depends on the assumption that managers are relatively inefficient (less than $50 \%$ efficiency) at extracting private benefits. Where managers are more than $50 \%$ efficient at extracting private benefits, the possibility exists that the managers may seek to commit to a level of private benefits greater than $X_{n b}$. At higher levels of private benefit expropriation, the inefficiency from theft is increasing (as managers find it more difficult to hide their expropriation from various legal barriers). Thus, the assumption of less than $50 \%$ efficiency is plausible (at least at higher levels of theft). Moreover, regulators may adjust the level of efficiency with which managers transfer side payments to outside block shareholders. Below, we argue that regulators may wish to allow managers to make direct cash payments to outside block shareholders. See infra Part IV.A.l. Nothing stops regulators from imposing a tax on such payments. A tax on side payments has the same effect as increased manager expropriation inefficiency: for each dollar that a manager expropriates, less than one dollar is available to transfer to the outside block shareholder, making accommodation more costly. Too high a tax, of course, may lead managers to shift their side payments back toward more indirect routes (such as shifting corporate opportunities).

214. Where $X_{b}$ is equal to $3.67 \%$ the amount of rents extracted (measured from Period 1 ) is equal to $0.0367 \cdot(\$ 1.1$ billion $) /(1.1)$ or $\$ 36.7$ million. When managers suffer from only a $40 \%$ efficiency in extraction (due to fiduciary duty constraints among other things) this leaves only $\$ 14.68$ million of rents. A half-share of the rents therefore is equal to $\$ 7.34$ million. 
manager finds it less profitable to split a larger private benefits pie with $B$ than it is to consume a small one alone. If given the choice, then, $M$ would opt for deterrence over accommodation, selecting a small enough value of $X_{b}$ to ensure that $B$ never finds it profitable to buy a toehold for its hold-up value. It is this calculation that is at the core of a central argument in this Article: Permitting favoritism may, ironically, induce more conscientious stewardship by incumbent management; who must now work harder to deter the entry of opportunistic investors seeking to extract side payments in exchange for their quiescence.

Second, note that this deterrence effect has an important impact on share value when compared to the case where bargaining was not allowed. Recall that in that case, $M$ would set $X_{n b}=3.67 \%$, and the resulting share price would be $\$ 96.33$. When bargaining is allowed in this example, $M$ chooses an even more extreme form of deterrence, setting $X_{b}=2.12 \%$, so that the resulting Period 1 share price is $\$ 97.88$, a gain of $\$ 1.55$ per share over the prohibitionist status quo ante. Spread across the 10 million shares outstanding in Acme, this implies that allowing favoritism would confer a gain on nonblock shareholders as a whole of over $\$ 15$ million. Moreover, this figure is not merely a transfer payment from management to shareholders, but a bona fide efficiency gain. Given that $M$ only benefits by forty cents on the dollar, the $\$ 15$ million worth of recaptured value comes at a cost of only $\$ 6$ million to $M^{215}$ On a related note, in our model it turns out that $B$ does not actually benefit from the legal status of favoritism one way or another. Indeed, in either case, $M$ deliberately constrains itself to induce $B$ to walk away from any purchases, and thus $B$ 's payoff is zero regardless of whether favoritism is allowed or prohibited.

Finally, note that even if $M$ decided (against its own interests) to accommodate rather than to deter $B$, the level of private benefits $M$ would choose is no higher than (and is in fact exactly the same as) that chosen under a regime of prohibition. In other words, even in the worst case scenario, where coalitions form between $M$ and $B$, it is far from clear that $M$ will choose to divert more value than it would in a world where favoritism is prohibited. On the one hand, the result may be somewhat more sensitive to the actual numerical parameters chosen. ${ }^{216}$ Nonetheless, even where our formal model may indicate that $M$ may wish to appropriate

215. At the same time, however, shareholders must pay differential taxes on this capital gain, which would be a portion of social welfare but not of organizational welfare. But even accounting for these taxes as per the model, the recapturing of $\$ 15$ million dollars in value confers an after-tax benefit of $\$ 1.5$ million on the corporation.

216. See supra note 213. 
a level of private benefits greater than where bribes are prohibited, for good reasons the amount of such benefits is limited. In particular, when $M$ decides to form a coalition with $B, M$ still runs a real risk of setting $X$ "too high": By extracting too much of the firm's value, $M$ might drive share prices so low that $B$ would prefer to engineer an outright takeover, leaving $M$ out in the cold. Recall, the path of accommodation entails splitting the spoils between $M$ and $B$. If Acme becomes too tempting a takeover target, $B$ would prefer to buy it outright than to share any surplus with $M$. It is this fear that induces $M$ to be relatively conservative about appropriating firm value even when it envisions a coalition with $B$. As such, from the incumbent shareholders' perspective, allowing favoritism in this example is a no-lose proposition-it is either strictly preferable to prohibition (i.e., when $M$ chooses deterrence), or is identical to it (when $M$ chooses accommodation).

Reiterating our main points, allowing patronage from managers to block shareholders that work to entrench management may, on first blush, seem to reduce overall corporate welfare. From an ex ante perspective, however, the possibility that outside investors may assemble blocks of shares simply to extract a bribe from management may have underappreciated positive welfare implications: In particular, it creates an added incentive for management to work hard so as to avoid being held up by opportunistic block shareholders. Viewed in this sense, two wrongs can indeed make a right. Opportunism on the part of outside investors seeking a bribe can dampen the effect of managerial agency costs, causing managers to commit to a lower level of private benefits to deter the outside investors from forming a block in the first place. Although managers may gain from a coalition with the outside investor, they must share part of the gain with the investor. In the case where bargaining power is roughly equal, managers will tend to prefer not to share. Forming a coalition means that managers must compensate the block shareholder for the loss on their shares due to the private benefits in addition to splitting any surplus. As well, outside constraints from fiduciary duties and reputational concerns may limit the ability of managers to increase radically the amount of private benefits they appropriate even with the possibility of a coalition with a block shareholder.

\section{CAveAts And CRitical Assumptions}

As with most economic arguments premised on a theoretical model, our analysis has invoked a number of assumptions intended to simplify the analysis and isolate the most critical interactions at play. While such 
simplifications are quite standard for economic models, we would be remiss to rely too confidently on the numerical results above without exploring whether-and to what extent-they depend critically on assumptions that are either implausible or cannot withstand being relaxed. To the extent that they do so depend, we would be forced to cabin the practical reach of our theory accordingly. In this Section, then, we briefly explore what we believe to be the five assumptions of our model that are most open to question, assessing (a) their realism, and/or (b) the robustness of our argument to their relaxation.

\section{Premiums and Block Size}

A central conceptual feature of our model relates to the cost of purchasing shares in the market. Indeed, key to our analysis is the assumption that outside investors must pay a premium over the prevailing secondary market price to construct a block, and that this premium increases on the margin with the size of the block purchased. Consequently, we argued, it is significantly cheaper on a per-share basis for $B$ to form a modest toehold (as a baseline for subsequent bargaining) than it is to engineer an outright acquisition. It is management's knowledge (and fear) of this modest toehold cost that induces $M$ to work particularly selflessly in situations where favoritism is allowed. Clearly, then, if the required premium did not increase with block size, the cost advantage of a forming toehold would begin to narrow. As such, the advantage for management of choosing deterrence over accommodation also becomes less pronounced.

Nevertheless, we contend that our assumptions about premia and block size are eminently realistic, and, in any event, not absolutely critical to the model. First, both intuitively and empirically, there are numerous reasons to believe that block purchases become more costly as the block size increases. As explored in our model above, shareholders may face differential tax consequences from selling their shares. At one end of the spectrum are nonprofit institutions that are not subject to any tax from selling their shares. ${ }^{217}$ Where shares have appreciated in value, nonprofit institutions will be the most willing, all other things being equal, to part with their shares for any given price. Shareholders that face a tax on the sale of their shares, on the other hand, give up the deferral of tax on this gain and therefore may require a premium in compensation. Among taxable investors, the U.S. tax laws impose two levels of tax. Gains on

217. See I.R.C. $\$ 501(c)(3)$ (1994). 
shares held under one year are subject to ordinary income tax. ${ }^{218}$ Gains on shares held for one year or more, on the other hand, are limited to the longterm capital gains rate ceiling. ${ }^{219}$ Shareholders with a mix of more recently purchased shares will face primarily ordinary income rates while those with a mix consisting more of shares purchased over one year in the past will face lower rates. Moreover, where the stock price is volatile, some shareholders may hold a portfolio of shares in the same company with different size gains and losses (depending on when the shares were purchased), thereby receiving differential tax treatment based on their relative mix of gains and losses. 220

But even beyond tax liability, upward-sloping supply curves can be artifacts of other realistic phenomena. For example, shareholders may hold heterogeneous expectations with respect to the value of a particular firm. ${ }^{221}$ Determining the true value of a firm's shares is both a costly and uncertain process. Shareholders with different beliefs and information may hold varying expectations about firm value. Although the market price may reflect the median valuation, individual shareholders may differ around this median. ${ }^{222}$ Any outside investor seeking to assemble a block then will find it initially less costly to purchase shares as those shareholders with a belief that the share price is overvalued sell their shares. As the block size increases, however, the outside investor must purchase shares increasingly from investors that hold beliefs that the secondary market price undervalues the firm.

Alternatively, shareholders that construct relatively small blocks do not face any mandatory disclosure requirements under the federal securities laws. Once a block shareholder beneficially owns greater than $5 \%$ of the outstanding shares of a company, however, the Williams Act imposes reporting requirements on the shareholder. Section $14(\mathrm{~d})(1)$ of the Williams Act, in particular, requires the owner of more than $5 \%$ of a class of a firm's securities to make a filing with the SEC containing information

218. Termed "short-term capital gains," taxpayers may use such gains to offset capital losses without limit. See I.R.C. \$ 1211 .

219. Termed "long-tcrm capital gains," taxpayers presently face a $20 \%$ maximum tax rate for such gains. Taxpayers in the $15 \%$ tax bracket face a $10 \%$ maximum tax rate. See I.R.C. $\S 1(\mathrm{~h})$.

220. For example, Jake is an investor in Acme. Jake may have purchased 1,000 shares in Acme over a year ago at fifty dollars per share. Jake may have also purchased 2,000 shares six months ago at a cost of $\$ 200$ per share. Given Acme's present secondary market price of $\$ 100$ per share, Jake will face a capital gains tax on the 1,000 shares purchased over a year ago as well as a potential short-term capital loss deduction on the 2,000 shares purchased six months ago.

221. See Stout, supra note 44, at 625-35 (1995) (advancing the theory that investors in the stock market may hold heterogeneous expectations as to share values).

222. See id. 
disclosure required under Section 13(d) of the Williams Act and the SEC's own rules and regulations. ${ }^{223}$ The required disclosure items include the identity of the owner; the source and amount of the funds used to make the purchase; and any plans the owner may have to liquidate, merge, and make a major change to the corporation if the purpose of the owner is to acquire control. $^{224}$ To the extent the market reacts to news of the formation of a large block positively, the cost to the outside investor of constructing a larger block increases. The market, for example, may take the construction of a large block as a sign that a takeover of the firm is more likely. Even past the $5 \%$ threshold, announcements of the intention to assemble increasingly larger blocks provide a stronger signal of a potential takeover to the market, leading to a larger secondary market price increase and thereby a higher cost to purchase additional shares in the block. ${ }^{225}$ Consequently, then, our assumption that the supply curve for Acme's shares is upward sloping does not appear to be overly brave or unrealistic. On the contrary, there are many good reasons to believe that shares of virtually any publicly traded firm have similar qualitative characteristics.

But even if one were not prepared to accept this assumption, it is not absolutely necessary for our principal thesis to hold. 1ndeed, so long as the block shareholder must pay some premium on the margin over fair actuarial value to buy Acme's shares, purchasing a toehold in order to extract a side payment can still dominate a hostile acquisition. Where a premium exists for each share (even if not increasing in block size), the block shareholder still has the ability to reduce its incremental costs of engaging in a takeover through the prior purchase of a toehold. Through a toehold (and the sunk cost expense of assembling the toehold), the block shareholder may increase the credibility of the takeover threat and thereby extract part of the managers' private benefits of control. Thus, while our assumption about increasing marginal premiums accentuates the quantitative aspect of our argument, it is not altogether critical for our qualitative thesis to hold.

\section{Credible Commitments}

A second critical assumption in our analysis is that managers are able to use corporate governance or other mechanisms to commit up front to a

223. See 15 U.S.C. $\$ 78 \mathrm{n}(\mathrm{d})(1)(2000)$.

224. See id. $\$ 78 \mathrm{~m}(\mathrm{~d})(1)(\mathrm{A})-(\mathrm{C})$.

225. On the other hand, outside acquirers that conduct a coercive tender offer may "force" outside investors to tender their shares for less than their actual value. For a general discussion, see Lucian Arye Bebchuk, Toward Undistorted Choice and Equal Treatment in Corporate Takeovers, 98 HARV. L. REV. 1695, 1696 (1985) (dcscribing the impact of coercive tender offers on efficiency). 
ceiling on their ability to appropriate firm value, and in a fashion that is binding on potential acquirers. Without such an ability to commit, managers may not credibly deter the entrance of a block shareholder. For example, recall that absent a threat from the takeover market, Acme's management would appropriate all of the firm's value of $\$ 1.1$ billion. ${ }^{226}$ Eager to exploit this potential, Acme's management might consider simply "announcing" that they plan to appropriate only $\$ 20$ million worth of the company's assets. Without any form of commitment, however, once the outside investor passes on the opportunity to form a toehold block, Acme's managers would simply appropriate the full value of the firm. Realizing this commitment problem, the outside investor will treat Acme's managers' representations as mere "cheap talk," treating matters as if Acme management had made no representations whatsoever. Thus, for the deterrence arguments in this paper to work, it is important that managers have the capacity to commit credibly to an upper bound on their ability to appropriate value.

As above, however, we contend that this assumption is also quite plausible. In fact, several methods exist for Acme's managers to commit to a particular level of private benefits. First, managers may utilize various corporate governance devices to control the possibility of managerial opportunism. For example, managers may install a board of directors consisting of outside independent directors with a reputational interest in monitoring managers. The credibility of such a board over time, moreover, may be enhanced through the use of a staggered board structure that limits the ability of managers and shareholders to remove certain directors without significant delay. Alternatively, the corporation could employ a confidential voting policy aimed at increasing the willingness of shareholders to vote against management during a proxy contest. Although managers may later attempt to reverse such corporate governance choices, reversal may be difficult. Reversal, for example, may send a negative signal to the market reducing share value and attracting the attention of potential corporate acquirers. Managers may also commit to certain devices through a corporate charter amendment to reduce the risk of reversal. $^{227}$

226. Note that this result abstracts from other mechanisms that may constrain the ability of mamagers to expropriate private benefits including contractual devices, reputation, and fiduciary duties. Nonetheless, the point remains that the amount of private benefits that managers may expropriate increases absent the ever present threat of a takeover.

227. For example, managers may place a term in the corporate charter requiring a two-thirds supermajority vote on the part of shareholders to approvc a reversal. 
A second means of commitment is to utilize state corporate law more directly. Managers may incorporate the firm in a state with more stringent fiduciary duty standards or weaker derivative suit demand requirements on shareholders. To the extent reincorporation requires a shareholder vote, managers lose the ability to exit unilaterally from the state law fiduciary duty protections. ${ }^{228}$ Managers may also choose to initiate the process to opt-out of state law antitakeover devices. ${ }^{229}$ State law fiduciary duties also often place great importance on the status quo. Given the business judgment rule, managers enjoy great leeway in the amount of private benefits they may appropriate from the firm. Courts often lack the expertise to assess directly the value of particular managerial decisions. Once a particular management team chooses to appropriate a particular level of private benefits, however, courts then have a benchmark for the level of shareholder value possible in the firm. To the extent the managers choose to increase drastically the amount they appropriate from the firm resulting in a large drop in corporate profits, courts and shareholders may use this as a signal that managerial opportunism has increased. ${ }^{230}$ Other factors, of course, may cause a drop in corporate profits; nevertheless, the signal may be particularly strong when a new control block shareholder immune to subsequent takeover assumes control over the firm.

Third, managers may choose to have the firm take on a higher level of debt financing. A greater amount of debt forces the firm to pay out its free cash flow to the debtholders. ${ }^{231}$ To the extent managers seek to avoid financial distress, managers will then have an incentive to engage in projects that generate cash flow instead of projects more geared to their

228. See Lucian Arye Bebchuk, Federalism and the Corporation: The Desirable Limits on State Competition in Corporate Law, 105 HARV. L. REv. 1435, 1460 (1992) (noting that while shareholders have to power to approve a corporate reincorporation only the board of directors may initiate a reincorporation).

229. In Delaware, for example, a decision to opt out of section 203's moratorium period as a categorical matter requires an amendment to either the company's charter or the by-laws, through a vote of the shareholders. See Del. CodE ANN. tit. 8, § 203(b)(3) (1998). The board could propose such a charter or by-law amendment at an annual or special shareholder meeting.

230. Russia has provided examples of corporations where large drops in the amount of corporate profits may indicate opportunism. See Bernard Black, Reinier Kraakman, \& Anna Tarassova, Russian Privatization and Corporate Governance: What Went Wrong?, 52 STAN. L. REV. 1731 (2000) (describing how the Russian corporation "Noyabrskneftegaz earned $\$ 600$ million in 1996, before [Boris] Berezovski acquired control of Sibneft [Noyabrskneftegaz's parent company], and \$0 in 1997. Most of the missing $\$ 600$ million showed up as Sibneft profit, even though under the company law, transactions between parent and subsidiary require approval by the subsidiary's minority shareholders, which was never obtained.").

231. See Michael C. Jensen, Agency Costs of Free Cash Flow, Corporate Finance, and Takeovers, 76 Am. Econ. ReV., PAPERS \& Proc. 323, 324 (May 1986); Rene M. Stulz, Managerial Discretion and Optimal Financing Policies, 26 J. Fin. ECON. 3 (1990). 
own personal preferences. Managers, as well, will be forced to pay out this cash flow to the debtholders rather than re-invest the cash into a valuereducing project that increases the managers' own welfare.

Fourth, managers may install long-term executive compensation packages that rely on options and other means of aligning the incentives of managers and their shareholders. Managers with option-based compensation, for example, possess a reduced incentive to appropriate private benefits of control to the extent their options suffer a reduction in value as a result. ${ }^{232}$

Fifth, managers may enter into long-term contracts with particular customers and suppliers that penalize the firm for failing to meet certain targets. For example, a contract with a customer may require the delivery of a set amount of products at a fixed quality level. Failure to meet the terms of the contract may result in a large penalty payment that reduces the amount of value available for managers to appropriate or places the firm at risk of financial distress. Such a contract may therefore force managers to operate the firm at the minimum level of efficiency necessary to ensure that the customer's contract terms are met. Managers seeking to appropriate value from the firm through a reduction in work effort, for example, may find a decreased ability to do so given a long-term supply contract with large penalty terms. Managers that seek to appropriate value through the diversion of production to their own benefit, as well, may face a reduced ability to make such diversion. ${ }^{233}$

And finally, Acme management itself may develop a long-term reputation that acts as a commitment device. A manager, for example, may enjoy a reputation as a low appropriator of private benefits. Because of this reputation, the manager is able to negotiate for a higher compensation package, making the reputation valuable to the manager. ${ }^{234}$ Rather than risk the reputation, the manager may therefore limit the amount appropriated to levels consistent with that reputation.

Significantly, not all commitment devices are created equal. While some are easily negated by management's successors, others have a significantly longer shelf life. Firms that rely on the reputation of incumbent managers, for example, often face an entirely new slate of

232. For a discussion of the usefulness of executive compensation as a means of controlling managerial agency problems see Robert Dean Ellis, Equity Derivatives, Executive Compensation, and Agency Costs, 35 Hous. L. Rev. 399 (1998).

233. On a related note, a robust competitive product market also reduces the ability of managers to appropriate private benefits. See Easterbrook, supra note 4, at 564 .

234. See Alchain, supra note 5 (discussing the incentive effect of the labor market for managers). 
managers after a change of control, and thus any reputation-based commitments made by the erstwhile management would be virtually irrelevant once an acquisition has occurred. Other commitment devices, however, such as long-term contracts, financial leverage, and restrictive debt covenants are likely to remain potent long after a control shift. As well, the state of incorporation may also remain the same. We would predict, therefore, that the favored forms of commitment devices are those that are also durable, robust to changes in management. With a long-lived limitation on their expected private benefits, outside investors may not expect to gain as much from appropriating private benefits and instead seek only to gain pro rata with other shareholders.

Of course, if we are correct in arguing that managers have significant abilities to commit to a ceiling on their private benefits, we must also address the affiliated question of why firms would ever want to leave managers any flexibility to commit in the first place. Put another way, one might legitimately wonder why the incorporators and promoters of the firm wouldn't simply pre-commit its subsequent managers to some maximum level of private benefits at the time of the initial corporate charter. ${ }^{235}$ To the extent private benefits of control result in value transferred from shareholders to managers, the argument goes, shareholders that initially invest in the firm will reduce their willingness to pay for the firm's shares. The incorporators of the firm may increase the amount they receive from the initial sale of securities to the public through the adoption of limits on such private benefits.

While we believe this argument to be a strong one in some instances, as noted above $\mathrm{e}^{236}$ its usefulness is limited by the costs of setting up such ex ante schemes. Indeed, for the incorporationist argument to work, it must be the case that the incorporators can anticipate with significant accuracy all the ways in which managers can appropriate value, and formulate effective means of tying their hands from doing so. Such ex ante approaches to governance, however, rarely come at a low cost, particularly in the early stages of forming a corporation, where the vicissitudes of the firm's business environment have yet to run their course. Instead, within such an environment, incorporators may wish to give their managers flexibility to determine how to monitor for managerial diversion of private benefits of control. To the extent that specifying fully state-contingent corporate charters is prohibitively costly, then, giving managers the flexibility to

235. See, e.g., Jensen \& Meckling, supra note 1, at 305-07.

236. See supra notes $26-27$ and accompanying text. 
determine the mix of optimal monitoring and incentive devices to control managerial opportunism may work to increase shareholder welfare.

Consequently, it may be more prudent and less costly for incorporators to let the market for corporate control induce managers to make their own decisions about how to select value-maximizing corporate governance devices. Once given such an incentive, managers are able to use their own expertise and informational advantage to select the most efficient forms of corporate governance devices, without requiring the founders of the firm to expend considerable resources on anticipating them. When the acquisitions market is a relatively effective means of deterrence (and we have argued that allowing favoritism may make it even more so), such a strategy can make a great deal of sense.

\section{Relative Bargaining Power}

Another important assumption of our model concerns the bargaining power of incumbent management relative to the outside investor. Recall that in the numerical example above, we assumed that $M$ and $B$ split any gains from bargaining in equal portions. While this seems a sensible assumption in the abstract, it implicitly presupposes that the parties are similarly situated, sophisticated, and patient. Because there are plausibly bargaining settings in the real world that differ from these preconditions, it is important to consider how our conclusions might change if one player had significantly more bargaining power than the other.

Perhaps the best vehicle for addressing this question is to consider the two "extreme" cases in which either $B$ or $M$ possesses all the bargaining power. Consider first the case where the outside investor $B$ has the power to make a "take it or leave it" offer, extracting the full value of the surplus from $M$. Such a situation is not terribly implausible, given that many block shareholders are large, well-capitalized arbitrageurs and institutions, capable of having great influence on corporate management. In such a situation, as it turns out, our central thesis not only persists, but it is actually strengthened by having a strong bargainer as a block shareholder.

To understand the intuition behind this result, recall that when bargaining is permitted the principal purpose that $B$ has for building an initial toehold is to become a "credible" threat of a takeover: That is, $B$ wishes to build a sufficient ownership block so that $B$ 's prospective net benefits of completing a takeover of Acme are positive (even if just barely so). At this point, $B$ would be able to claim a share of the difference between $B$ 's prospective takeover payoff and the incumbent manager's 
payoff in the absence of a takeover. When the block shareholder possesses all the bargaining power, the payoff it can expect from becoming a credible negotiator grows even larger than in our baseline case of equal bargaining power. Indeed, now $B$ enjoys more than simply a "share" of the bargaining surplus, but instead can claim all of it. As such, $B$ will be willing (if necessary) to build even a larger toehold when $B$ knows it can expect all the fruits of the bargain.

For these very same reasons, then, player $M$ has even stronger reasons to fear $B$ 's entry, and will even more strongly favor deterrence over accommodation. Indeed, if $M$ were to accommodate $B$, it would now necessitate a bribe that robs $M$ of all private benefits of control, leaving $M$ with nothing. As such, $M$ is substantially more motivated to deter $B$ from entering in those situations where $B$ has most or all of the bargaining power. Accordingly, $M$ will choose an even sharper constraint on the ability to appropriate value. . $^{237}$

Now consider the opposite case, in which $M$ has sufficient bargaining power to capture the entire surplus from forming a coalition. In this case, the incumbent manager is much less fearful of a block shareholder who forms a toehold. Indeed, when $M$ possesses all the bargaining power, all gains from negotiating go directly to $M$; player $B$ receives nothing more than the expected takeover payoff. Consequently, $B$ has very little incentive to form a credible toehold in the first place, given that it cannot extract any additional rents from player $M$. Thus, when $M$ has all the bargaining power, the players will behave just as if bargaining were prohibited, with $M$ committing to appropriate at most $3.67 \%$ of firm value, ${ }^{238}$ and $B$ deciding against forming a toehold.

From this discussion, it should be clear that the benefits of allowing favoritism are most pronounced when the incumbent manager's bargaining power is not "too large" compared with the block shareholder. For only in those situations will management have a clear incentive to deter the formation of a toehold block of shares. Such was the case when either $B$ had all the bargaining power or when $M$ and $B$ have equal bargaining powers. When, in contrast, managers have much or all of the bargaining power, permitting favoritism does not have a clear advantage over prohibition. Nevertheless, as noted above, even in this situation, permitting

237. Indeed, when $B$ has all the bargaining power, the unique equilibrium of the model entails $M$ deciding to constrain itself even further, committing to appropriate no more than $1.70 \%$ of the firm's value (compared to $2.12 \%$ in the equal bargaining power case).

238. See supra text accompanying notes 190-91 (noting that $3.67 \%$ represents the benchmark level of managerial expropriation of private benefits when shareholder favoritism is prohibited). 
favoritism may simply bring about the same equilibrium outcome as does prohibition. Although $B$ may choose not to form a toehold and negotiate a coalition with $M, B$ may still undertake an outright takeover to displace $M$ when private benefits are sufficiently high. As such, even though our bargaining power assumption is important, a weak form of our argument still holds regardless of the parties' relative bargaining power.

\section{Thick Acquisition Markets}

Fourth, our analysis simplified strategic considerations by assuming that there was but a single outside investor (that is, $B$ ) capable of mounting a hostile acquisition of the company. In the real world, where capital markets are well developed and arbitrageurs are numerous, this assumption appears to be somewhat limited. One might justifiably wonder, then, how we might generalize our example to allow for two, three, or an arbitrary number of "N" potential block shareholders, each of whom was capable of purchasing up to a control block in the company.

As it turns out, our model is capable of such a generalization, albeit at the price of added complexity. Without going too far into the details, however, generalizing our example to allow for multiple block shareholders actually strengthens our central thesis rather than undercutting it. The intuition here is simple: When multiple block shareholders await in the wings, incumbent managers who might otherwise prefer to form a coalition must now worry about having to make multiple bribes in order to retain control. ${ }^{239}$ Particularly since their initial toehold purchases can be relatively small, each block shareholder now poses the credible threat of completing a takeover. Thus, since we have demonstrated that incumbent management has an incentive to choose deterrence over accommodation with only one outside investor in the picture, this incentive almost certainly becomes stronger when multiple block shareholders stand at the ready. Indeed, because each of the investors is similarly situated, choosing a level of $X$ private benefits sufficient to deter one of them would have a similar effect on all investors. Thus, we are relatively confident that our central arguments would have as much or more force in a more realistic setting where the takeover market harbors numerous potential acquirers.

239. Having multiple parties willing to purchase a significant block is quite possible in the capital markets. Michael Bradley, Anand Desai, and E. Han Kim found that $46 \%$ of tender offer contests during early 1980 s involved a multiple bidder situation. See Michael Bradley, Anand Desai \& E. Han Kim, Synergistic Gains from Corporate Acquisitions and Their Division Between the Stockholders of Target and Acquiring Firms, 21 J. FiN. ECON. 3, 29 (1988). 


\section{Initial Ownership Structure}

Finally, our analysis above has presumed throughout that the firm's shareholdings begin from a dispersed position, where no existing shareholder owns an appreciable stake. This assumption was deliberate, particularly given that managerial agency problems are perceived to be most pronounced in such situations. At the same time, however, our argument was based on the premise that allowing patronage would cause managers to act in ways that deter opportunistic block shareholders from emerging. When a block shareholder already exists, however, such deterrence arguments are significantly less coherent.

Consequently, we acknowledge that our theoretical argument is substantially weaker for firms who already have significant block shareholding in place. For here, allowing favoritism may induce incumbent block shareholders simply to extract side payments, providing little incentive for managers to take deterrent action. To be sure, preexisting block shareholders may serve other valuable purposes, such as monitoring the firm's managers, which we have downplayed in the above analysis. ${ }^{240}$ To the extent that this monitoring effect is pronounced, there may be an independent justification for favoritism that emanates for reasons outside those offered above.

\section{REFORM POSSIBILITIES}

With the conclusions of the previous subsection in hand, we turn in this Part to a more policy-oriented discussion of the regulatory reform possibilities suggested by these conclusions. To be sure, one must always exercise a prudent dose of caution in interpreting results from theoretical models such as that presented above. But at the same time, the intuitions that such models expose may deserve serious consideration by Iegislatures, courts, and other policymakers. It is these very intuitions (and their implications) that we pursue below.

One of the more important insights from the previous section is that the very form of opportunism that regulators fear in the context of shareholder favoritism can, ironically, serve as a beneficial restraint on managerial self-dealing at the ex ante stage. As such, efficiency-minded regulators would be well advised to keep this potential benefit in mind, focusing less on whether "opportunism" has motivated some instance of favoritism, but rather on whether the requisite preconditions exist for

240. Indeed, this is precisely the argument offered in Ayres \& Cramton, supra note 148. 
favoritism to have the efficiency-enhancing ex ante effects we have suggested. Such conditions include the following:

a. Whether the block shareholder extracting favoritism is relatively new (rather than a preexisting block shareholder);

b. Whether there are numerous potential purchasers of blocks;

c. Whether incumbent management's bargaining power against the block shareholder is not "too large";

d. Whether management has credible devices at its disposal by which it might constrain its own ability to appropriate value; and

e. Whether purchasing a block of shares requires the payment of a premium over fair market value.

Indeed, considerations such as these could (and, we believe, should) come into play when courts evaluate the particular forms of shareholder patronage outlined in Part II. Section A discusses various reforms regulators may wish to consider within the present regulatory framework. Section $B$ raises several additional concerns regulators may wish to consider. Section $\mathrm{C}$ then sketches a new market-based approach to regulating selective payments to shareholders.

\section{A. REFORMS TO THE REgULATORY SYSTEM}

It is perhaps no overstatement to characterize much of the existing corporate governance landscape as focusing centrally on preventing opportunism. Indeed, it is widely recognized that corporate law focuses on the agency problem between managers and dispersed public shareholders (and, in some cases, other constituencies). The regulatory prohibitions against many forms of selective payments, therefore, draw much of their legitimacy from the putative dangers implicit in managerial opportunism. ${ }^{241}$ To the extent, however, that the intuitions exposed above are valid, regulators would be well advised to apply their scrutiny only after accounting for the efficiency-promoting effects on opportunism. Such considerations may play a role in a number of existing doctrines governing shareholder favoritism, and we therefore revisit some of them below.

241. See supra Part 1I. 


\section{Selective Payments Reconsidered}

As noted in Part II, conventional wisdom reflects significant skepticism about shareholder patronage, viewing it as a manifestation of managerial opportunism. Regulators have responded to this perceived risk by systematically prohibiting such selective patronage, starting-quite logically - with those types of favoritism that are easiest to verify (such as outright non-pro rata distributions of cash and property). Over time, such legal prohibitions have expanded piecemeal to proscribe successively less verifiable categories of patronage, in a sort of regulatory back-and-forth game with managers, who in turn respond by shifting their activities toward more indirect and opaque mechanisms of patronage. ${ }^{242}$

As we have already suggested, this regulatory dance may impose significant inefficiencies, since indirect forms of patronage are likely to be progressively more costly to implement and confer less value on recipients (resulting in a dead weight loss from an efficiency perspective). The potential inefficiency becomes even more severe, however, if shareholder favoritism has a welfare-enhancing effect on corporations. Most obviously, our arguments suggest that regulators should think twice before categorically banning a form of patronage simply because of perceived opportunism. While such payments may indeed have an opportunistic intent, we have argued that the very ability to make such payments can impose an even stronger ex ante deterrent effect on managers. Permitting such payments becomes attractive precisely because it will induce managers to choose the path of deterrence, thereby bypassing the necessity to make such transfers (at least under the conditions specified above).

More subtly, however, once regulators understand that even opportunistic payments can enhance corporate welfare, it follows that the efficacy of favoritism is maximized when the medium for conferring patronage is as direct as possible. Viewed in this light, distributions consisting of outright transfers of cash or property are, ironically, the best vehicles of deterrence, in that they avoid the inefficiencies involved in indirect forms of patronage. ${ }^{243}$ For example, direct payments provide a clear and verifiable form of rent transfer upon which outside potential block shareholders may rely. The uncertainty in the value of "in kind" transfers, in contrast (such as selective information disclosure), affords managers the ability to conceal the amount of transfer without the outside

242. For a taxonomy of different methods by which managers may favor particular shareholders, sec supra Part II.

243. See supra Part II. 
investor necessarily attributing the drop to the manager's actions. Outside investors, as a result, will treat such in kind patronage with enhanced skepticism, thereby diluting the deterrent effect we have spotlighted.

Regulators may therefore wish to relax prohibitions against selective cash distributions to favored shareholders (allowing such payments without regard to motivation). Doing so will result in a shift from opportunistic "in kind" transfers toward more direct cash favoritism, reducing the dead weight loss inefficiency from favoritism. Regulators can also assist the incentives of outside investors to form blocks along at least two additional dimensions. First, regulators may help the division of a private benefit surplus between managers and a toehold block through devices (such as enforcement of patronage contracts) designed to increase the credibility of both parties. In some situations, for instance, a firm may be sufficiently cash constrained that managers can only credibly promise to transfer funds over time to the toehold block. To ensure that the toehold block continues to support the managers into the future, managers may wish to stagger payments across time. Regulators, then, may be in a position to provide centralized mechanisms for enabling managers to commit to such longterm contracts. For example, regulators might help to encourage or suggest standard form agreements, standing ready to monitor and enforce such agreements.

Likewise, block shareholders also benefit from being able to commit credibly to support management into the future (in for example proxy contests) and abstaining from acquiring additional shares to obtain control. Regulators may enhance the credibility of such promises as well, providing legal liability for block shareholders who breach such a promise. Once again, the benefits of such credibility emanate from an ex ante perspective, where the ability of a block shareholder to extract patronage imposes increased pressure on managers to manage companies efficiently.

In some ways, these regulatory changes would not necessitate a complete overhaul of the existing system. Under current law in most states, for instance, shareholders already enjoy limited ability to enter into voting trusts and vote pooling agreements with one another. ${ }^{244}$ At the same time, however, various limitations exist on the use of such devices to bind a shareholder to support management, thereby rendering them less reliable than they might otherwise be. For example, even though Delaware law

244. See DEL. CODE ANN. tit. 8, § 218 (1998) (voting trusts and other voting arrangements). Through standstill agreements, moreover, shareholders may already agree to abstain from further purchases of a corporations stock in return for consideration. See supra note 10. 
permits any shareholder to sign over an irrevocable proxy as consideration for some other contractual agreement, it limits enforcement only to those that are "coupled with an interest sufficient in law to support an irrevocable power." 245 Given the open-ended nature of this condition, it is entirely possible for a court to conclude that the entrenching effect of an opportunistic agreement between incumbent management and a block shareholder is not of the type of envisioned by the statute. ${ }^{246}$

Second, regulators may assist the pool of potential outside investors by encouraging informational disclosure on existing relationships between managers and preexisting block shareholders. ${ }^{247}$ Consider an outside investor making the decision whether to assemble a toehold block of shares to extract rents from managers. Part of the uncertainty facing the outside investor is whether other blocks of shares are present in the market and their relationship with management. The presence of a competing block already in a coalition with management, for example, may raise the cost of a takeover for the new outside investor even after forming a toehold. The higher cost of a takeover, in turn, reduces the negotiating strength of the outside investor with management, reducing the expected amount of rent extraction. The added uncertainty imposes risk-bearing costs on the outside investor and may thereby deter formation of toehold blocks. Through mandating disclosure (through, for example, a publicity requirement frequently seen with voting trusts ${ }^{248}$ ), regulators may reduce the risk facing outside investors contemplating the formation of a block of shares.

As noted above, regulators should be mindful of the relative bargaining strengths of managers and outside toehold blocks in determining whether to allow selective payments. Recall that our principal argument is at its strongest when incumbent management did not wield "too much" bargaining power against the block shareholder. As such, a permissive legal posture toward favoritism is likely to have the greatest effect in precisely these situations.

245. DEL. CODE ANN. tit. $8, \S 212(\mathrm{e})$.

246. For a general discussion on the validity of voting trusts and vote pooling arrangements see 5 FLETCHER, supra note $52, \S 2064$. For a discussion of cases relating to voting trusts and vote pooling arrangements, see CLARK, supra note 1, at 772-81.

247. Already block shareholders with more than $5 \%$ beneficial ownership of a corporation's class of equity stoek must make a number of disclosures pursuant to the Williams Act. See supra note 78 and accompanying text.

248. See DEL. CODE ANN. tit. $8, \S 218$ (requiring a copy of a voting trust agreement to be filed with the Secretary of State and subject to inspection by other shareholders). 
At the same time, however, the relative bargaining strengths between managers and outside investors are often context-specific, and thus the task of developing a general rule is difficult. Nevertheless, regulators may still be able to identify some canonical situations where incumbent management is unlikely to dominate negotiations with block shareholders, and enforce patronage agreements in those contexts. Although we cannot offer a complete catalogue of such instances, they are likely to include situations in which (i) incumbent management stands to incur a large reputational loss should a hostile acquisition occur; or (ii) the outside investor has a reputation for effectively extracting rents from management. ${ }^{249}$

Alternatively, regulators might be able to modify directly the bargaining range itself, by perhaps conditioning their approval of patronage on whether the bribe received by the block shareholder exceeds a specified minimum amount. Managers with superior bargaining power that wish to payoff a particular toehold shareholder are then unable to do so with only a de minimis bribe but must exceed at least the regulatory minimum. Shareholders may then have an incentive to construct a block of shares even where managers otherwise hold most of the bargaining power.

\section{Fiduciary Duties}

State corporate law imposes significant mandatory restrictions on the ability of managers to appropriate private benefits in the form of fiduciary duties, and particularly the fiduciary duty of loyalty. Under the duty of loyalty, courts require that managers not profit at the expense of corporate welfare. ${ }^{250}$ The duty of loyalty, therefore, provides a mechanism that may complement the takeover market to help control managerial opportunism. For example, takeovers are most likely during a decline in share price, which in turn may deter managers from engaging in a series of small actions that extract value-actions that eventually have a large impact on share price. But for extremely large value diversions, takeovers may provide inadequate deterrence, since the risk of displacement would pale in comparison to the significant gains that managers might glean from a onetime act of disloyalty. The duty of loyalty, on the other hand, is well suited

249. Ironically, therefore, rather than condemn the so-called greenmail "artists" of the $1980 \mathrm{~s}$, we should be celebrating their actions. See Fred R. Bleakley, Outrage Over Disney Buyout, N.Y. TIMES, June 13, 1984, at D1.

250. In what has become perhaps the most celebrated statement of this duty, Judge Benjamin Cardozo famously wrote that the duty of loyalty required "[n]ot honesty alone, but the punctilio of an honor the most sensitive, is then the standard of behavior." Meinhard v. Salmon, 164 N.E. 545, 546 (N.Y. 1928). For more on the duty of loyalty see supra note 57. 
to regulate one-time acts of self-dealing. Litigants who can prove such breaches of the duty, then, will enjoy a much more secure avenue for redress.

Likewise, fiduciary duties can also play a complementary role in ensuring that managers, entering into a coalition with a toehold shareholder, are unable to increase substantially the amount of firm value they appropriate for themselves past the benchmark level where side payments are prohibited. ${ }^{251}$ Too high levels of expropriation, for example, may simply induce the outside block shareholder to takeover the firm outright. ${ }^{252}$ Managers, as a result, will tend to choose deterrence over accommodation even when shareholder favoritism is allowed. Imposing fiduciary duties that focus on egregious levels of private benefit expropriation on the part of managers (excluding selective payments to outside shareholders) serves as a safety net to ensure that managers will not increase their ability to extract private benefits through a coalition with a toehold shareholder.

At the same time, the potential complementary role of fiduciary duties does not come cost-free. The presence of fiduciary duties, for example, exposes a firm's managers to the possibility of costly and sometimes frivolous derivative suits, ${ }^{253}$ pursued simply to extract a settlement. Because of the expense inherent in such lawsuits, corporations may routinely settle derivative suits rather than expend resources in defense, no matter how legitimate the claim. ${ }^{254}$ Adding to this incentive to settle, director and officer (or "D\&O") liability insurance policies often will pay for settlements but not for judgments at trial. ${ }^{255}$ The value of fiduciary duties, moreover, may vary depending on the specific firm. In firms where managers have many opportunities to engage in significant episodes of rent extraction, fiduciary duties are likely to be much more valuable than in firms where such opportunities are more limited. Firms, for example, that

251. See supra text accompanying notes $208-15$.

252. See supra text accompanying notes $208-15$.

253. See Roberta Romano, The Shareholder Suit: Litigation Without Foundation?, 7 J.L. ECON. \& ORG. 55 (1991). For evidence of nonmeritorious securities litigation, see Janet Cooper Alexander, Do the Merits Matter? A Study of Settlements in Securities Class Actions, 43 STAN. L. REv. 497 (1991); James Bohn \& Stephen Choi, Fraud in the New-Issues Market: Empirical Evidence on Securities Class Actions, 144 U. PA. L. Rev. 903 (1996).

254. See Lucian Arye Bebchuk, A New Theory Concerning the Credibility and Success of Threats to Sue, 25 J. LeGal Stud. 1 (1996); Robert G. Bone, Modeling Frivolous Suits, 145 U. PA. L. REV. 519 (1997); David Rosenberg \& Steven Shavell, A Model in Which Suits Are Brought for Their Nuisance Value, 5 lNT'L REV. L. \& ECON. 3 (1985).

255. See Alcxander, supra note 253, at 550-51. 
operate in highly competitive markets may operate on such thin margins that managers cannot extract many rents without inviting bankruptcy.

Moreover, not every form of fiduciary duty is entirely complementary with our underlying thesis. In particular, it is important to note that state corporate law universally imposes fiduciary duties on dominant shareholders, including (perhaps) those who purchase a significant block ${ }^{256}$ seeking to extract rents from managers. Even though we have highlighted the potential benefits of such activities, courts with an eye toward fiduciary principles may treat a toehold block in coalition with management as equivalent to a controlling shareholder. The application of fiduciary duties to toehold blocks in coalition with management, then, can impair the ability of such shareholders to extract private benefits from management. Outside investors therefore will have a reduced incentive to form a block in the first place, thereby retarding the disciplining threat that shareholder patronage represents. Hence, while fiduciary duties are quite possibly a complement of our thesis, their application does not uniformly cohere with the arguments presented above. ${ }^{257}$ Regulators should not rely too comfortably on the ability of enhanced fiduciary duties to substitute for (or augment) takeover markets effectively.

\section{Antitakeover Devices and Statutes}

Obviously critical to our analysis of shareholder favoritism is the background possibility of a hostile takeover. Thus, if managers can implement antitakeover devices that reduce or completely cut off the possibility of a takeover, then two unappetizing consequences result. First, and most directly, managers become more entrenched, enjoying a greater

\footnotetext{
256. For Delaware cases imposing a duty of loyalty on controlling shareholders, see Paramount Communications, Inc. v. QVC Network, 637 A.2d 34, 43 (Del. 1994); Weinberger v. UOP, Inc., 457 A.2d 701, 709-10 (Del. 1982); Sinclair Oil Corp. v. Levien, 280 A.2d 717, 719 (Del. 1971); Sterling v. Mayflower Hotel Corp., 93 A.2d 107, 109-10 (Del. 1952). See also supra note 57 (discussing the fiduciary duty of loyalty).

For an examination of the fiduciary duty owed by controlling shareholders to minority shareholders, see John C. Carter, The Fiduciary Rights of Shareholders, 29 WM. \& MARY L. REV. 823, 831-36 (1988). See also Eric Seiler, Daniel M. Taitz, \& Ellen A. Harnick, Issues Relating to Controlling Shareholders, in PRACTISING LAw InSTITUTE, DoING DEALS: UNDERSTANDING THE NuTS AND Bolts of TRANSACTIONAL PRACTICE 455 (1996) (noting the uncertainty of court-based fiduciary duty doctrine as applied to controlling shareholders).

257. We would therefore allow managers to freely make payments to outside shareholders (and allow such shareholders to accept such payments) without regard to fiduciary duty. On the other hand, imposing a fiduciary duty on other actions that managers may take (e.g., executive compensation and self-dealing transactions directly involving the managers) will then help limit the amount of increased private benefit expropriation that is possible through a coalition between managers and outside shareholders.
} 
ability to appropriate private benefits without fear of a takeover. Consequently, in the presence of such measures, only those nontakeover methods of deterrence are likely to be effective. Fiduciary duties, for example, remain as one possible limit to excess opportunism even when antitakeover devices reduce the threat of a takeover. In addition, it may be possible for outside investors to use the proxy system to vote out a firm's current board of directors. ${ }^{258}$

Second, antitakeover provisions reduce the threat of an outside investor forming a toehold block to extract rents from management. This disincentive can be bad news for other shareholders, since-as we argued above- - the formation of a toehold can give the outside investor sufficient credibility to extract patronage from managers, an ability that ultimately deters agency costs. Antitakeover devices that reduce the threat of a takeover, then, also diminish the block shareholder's bargaining credibility, thereby deterring the formation of the toehold in the first place.

Consider, for example, antitakeover devices that impose a minimum amount of shares that a potential acquirer must own prior to obtaining control. Delaware, for example, employs a so-called control share acquisition statute. Contained within section 203 of Delaware's General Corporation Law, the control share acquisition statute prohibits persons acquiring $15 \%$ or more of a corporation's voting stock from undertaking a business combination without prior board approval for a three-year period. $^{259}$ Persons who cannot obtain board approval must either wait for the moratorium period to pass, or be willing to purchase at least $85 \%$ of the corporation's outstanding voting stock (excluding shares held by directors or officers of the corporation as well as certain employee-owned stock). ${ }^{260}$

Requiring an outside investor who seeks control to purchase a supermajority of shares makes takeovers considerably more difficult. Particularly where the cost of assembling a block is increasing with block size, outside investors may face prohibitively large costs putting together the larger required control block. In the context of the paper's framework, the prospective harm to managers occurs through the amount of rent a toehold shareholder is able to extract. Increasing the cost of a takeover

258. Firms, nevertheless, may install classified boards to deter the use of even proxy contests to change control.

259. See DeL. CODE ANN. tit. 8, § 203(a)(1) (1998).

260. See DEL. CODE ANN. tit. 8, \$203(a)(2). Other methods of avoiding board approval are possible. An acquirer, for example, may seek the approval of a supermajority of disinterested shareholders. See DEL. CODE ANN. tit. 8, § 203(a)(3). 
reduces the ability of the toehold at the time they bargain with managers to extract rents, thereby reducing the deterrent effect on managers. ${ }^{261}$

Despite the negative impact of antitakeover devices for our central thesis, some variation on Delaware's antitakeover statute may in fact have some salubrious effects. Recall that managers forming a coalition with a toehold block must compensate the shareholder for the reduced value of the shareholder's stake that the manager's appropriations will bring about. ${ }^{262}$ The larger the toehold, then, the more overall anticipated loss to shareholders that managers must internalize when paying off the block shareholder.

Notwithstanding this observation, recall also that the outside investor has an incentive to form the minimal possible toehold that still makes the takeover threat a credible one. Indeed, forming a larger toehold would buy the shareholder little in the way of bargaining credibility, and would come at significant cost. Indeed, for each dollar the outside investor expends to form a larger toehold, only a fraction of the resulting bargaining surplus can be recouped.

Regulators may be able to exploit these competing incentives by adopting a permissive view toward shareholder favoritism, but limited solely to those toehold blocks that meet a certain minimum level of ownership. Such a minimum share ownership requirement may work to push outside investors to form larger toeholds than they otherwise would, and under certain circumstances this might benefit all shareholders in a corporation. Indeed, now incumbent management will realize that it will have to make an even larger payment to buy off a block shareholder, and might have an enhanced incentive to reduce private benefits before such a shareholder emerges.

On the other hand, conditioning enforceability of patronage on minimum share ownership can also have counterproductive effects. For instance, setting the minimum too high can cause some outside investors to choose simply to forego assembling a toehold altogether (due to the

261. On the other hand, where the outside investor may seek to appropriate its own private benefits after a takeover, forcing the outside investor to conduct an acquisition with a larger control block may benefit all shareholders. Once the outside investor owns a larger control block, it will internalize more of the cost from private benefit appropriation, thereby deterring such appropriation.

262. Formally in the model, because the toehold shareholder owns a significant block, they benefit more from a takeover. The greater the private benefit level, the more the toehold block shareholder benefits from the takeover. Managers seeking to enter a coalition with the toehold block shareholder must then compensate the toehold block shareholder for its foregone takeover benefits when entering into the coalition. See supra notes $208-15$ and accompanying text. 
expense), notwithstanding the commitment by management to exercise restraint. Regulators must therefore take care in setting the minimum level of share ownership such that an outside investor will in fact seek to expand their block. Unlike under Delaware's present control share acquisition statute, ${ }^{263}$ regulators should also remove the ability of a corporation's board to waive application of the statute. Given such ability, managers will simply waive the minimum share ownership requirement to avoid the threat of larger toeholds.

\section{B. OTHER REFORM CONSIDERATIONS}

In designing policy to take into account the ex ante incentive effects of shareholder patronage, regulators may also wish to consider a few other considerations that affect this Article's analysis. This Section discusses two of them: (1) the possibility that managers may negotiate with a toehold block prior to committing to a maximum level of private benefits; and (2) the impact of manager-owned blocks.

\section{Timing of the Managers' Commitment}

This Article's analysis assumes that shareholders are initially dispersed and hold insignificant stakes. In such situations, of course, it is unlikely that managers will render patronage toward any prospective block shareholder before the purchase of a significant block. For example, managers may find it difficult to identify which existing shareholders have the liquidity to form a block of significant size. Even where identification is possible, managers may view the threat of an outside shareholder to form a block as not credible. Any outside shareholder may represent that it plans to assemble a block of shares to extract rents from managers, even though other outside options for such capital would in actuality be more attractive. Managers may therefore prefer to wait for a toehold to actually form in the market before commencing negotiations. Thus, in situations where firms truly begin with a relatively dispersed shareholder base, our assumption was probably well founded. ${ }^{264}$

In several real-world situations, however, managers may be able to negotiate with a prospective toehold block shareholder prior to committing

263. See DEL. CodE ANN. tit. 8, § 203(a)(1) (allowing the board of directors to approve a business combination with a shareholder that does not meet the minimum share ownership requirements of the statute).

264. But see supra note 30 (citing evidence that many companies outside the United States and the United Kingdom have significant block owners). 
to a fixed level of corporate governance. For example, firms with a pool of preexisting block shareholders may already have an obvious bargaining partner for management from the very beginning. Concentrated ownership may be particularly common for firms on the eve of a public offering, where a pool of preexisting blocks (e.g., founders, initial investors, and venture capitalists) enjoys close relations with managers. Second, and more generally, even within dispersed-ownership firms, managers may have the ability to identify particular outside investors with the credible capability of forming a block in advance. Some investors, for example, may have a reputation for forming blocks to extract rents from managers. This reputation may make the threat on the part of the outside investor to form a toehold credible to managers. ${ }^{265}$

If managers negotiate with a potential or preexisting block shareholder prior to making a commitment to a maximum level of private benefits, our central argument loses some of its force. Indeed, by locking up any outside threats before making any commitment about future expropriations, managers can exploit small-scale shareholders considerably. Returning to the Acme hypothetical, if Acme's managers are able to negotiate with an actual or potential block shareholder prior to committing to a maximum level of private benefits, they may buy the shareholder's quiescence, and then make no commitment at all, implicitly promising to loot the entire worth of the company. ${ }^{266}$ Such a deal must make managers better off than the alternatives, since the managers can always refuse to bargain and then commit to a ceiling of $X_{n b}$, thereby deterring any entry by a block shareholder. Managers therefore are more willing to make opportunistic bribes in a manner that reduces overall corporate value when bargaining precedes commitment.

Efficiency-minded regulators, then, would be wise to consider whether an instant situation affords management the ability to lock up preexisting or potential block shareholder prior to committing to a fixed level of private benefits. Regulators, for example, may apply greater scrutiny to agreements between managers and shareholders just prior to when a firm opts into a regime that permits favoritism. ${ }^{267}$ As well, regulators may choose not to enforce any agreements between managers

265. See, e.g., Cheff v. Mathes, 199 A.2d 548 (1964) (greenmail recipient had reputation for extracting rents from management).

266. In our model, this corresponds to $X=1$. Of course, fiduciary duties among other mechanisms act as external limits (not covered explicitly in our model) that also limit the ability of managers to expropriate private benefits of control.

267. See infra Part IV.C. (setting forth the argument that firms should have the ability to opt out of prohibitions against shareholder favoritism). 
and an outside investor negotiated prior to when an outside investor forms a toehold block. Or finally, regulators may wish to remain conscious of how competitive the takeover market is in each case: Where there are numerous possible block shareholders, reaching ex ante agreements with some of them may be of only little solace to management, who may rather simply choose the path of deterrence.

\section{Manager-Owned Blocks}

One possible response managers may have to the threat of outside investors forming a toehold block is to form their own block of shares. To be sure, this strategy is not always possible: In large publicly held corporations, for instance, managers may lack the financial resources to assemble a significant block, or would be forced to compromise the diversification of their portfolios in order to do so. Nevertheless, the possibility exists that managers in at least some firms may form a defensive block of shares.

Managers that hold defensive blocks of shares will increase the cost to outside investors seeking to form a block in at least two ways. First, the very presence of the managerial block raises the number of shares an outside investor might need to acquire in order to obtain "effective" control over the firm, as it can no longer count on as much support from unaffiliated shareholders. The larger the block an outside investor must form, the more expensive a takeover becomes. ${ }^{268}$ Second, managers who buy their own blocks are likely to purchase from existing shareholders who value their shares the least, because of different expectations as to firm value, varying tax rates, and so forth. ${ }^{269}$ Subsequent outside investors, therefore, may be left having to purchase shares from higher valuing shareholders, which increases the marginal cost of forming a block.

Despite the impact that a manager-owned block may have on the costs faced by potential acquirers, managerial block ownership is probably not a large cause for concern. Indeed, unlike fiduciaries who own no shares in a firm, managers that own a significant block will at least partially bear the cost of the appropriation of private benefits. ${ }^{270}$ The net effect of a manager-owned block is therefore inconclusive.

268. See supra Part III.C.1 (discussing the rationales behind this Article's assumption of an upward sloping supply curve for shares).

269. See supra Part III.C.1.

270. For example, managers that own $25 \%$ of the outstanding common stock will suffer a loss of twenty-five cents for every dollar they expropriate as private benefits. 
This fundamental indeterminacy appears to be borne out in empirical data as well. Randall Morck, Andrei Shleifer, and Robert Vishny have previously made the observation that the risk of a takeover alone can result in similar conflicting impacts from a management-owned block. ${ }^{271}$ On the one hand, the more shares management holds, the more expensive a takeover for an outside investor, leading to greater management entrenchment. On the other hand, the more shares in the hands of managers, the more managers internalize the cost of their appropriation of private benefits. For levels of board share ownership under 5\%, they find that overall firm value appears to increase in the size of the managerial stake. ${ }^{272}$ Between $5 \%$ and $25 \%$, board share ownership negatively correlates with firm value. ${ }^{273}$ Above $25 \%$ of absolute share ownership, increased board ownership again increases firm value. ${ }^{274}$

The ability to engage in opportunistic bribes raises the cost to managers from appropriating private benefits. Accumulating shares in a management-controlled block therefore will provide managers with a correspondingly higher benefit than where managers are faced solely with the risk of a takeover. All other things being equal, we conjecture that managers will accumulate larger blocks under a system where opportunistic bribes are allowed to outside shareholders. ${ }^{275}$ But at the same time, such accumulations should not necessarily raise the ire of regulators.

\section{MARKET-BASED REFORMS}

The reform suggestions thus far assume that regulators are able to assess correctly the costs and benefits of different methods of controlling managerial opportunism. Although perhaps defensible in some situations, it may be too much to presume as a general matter that regulators have sufficient knowledge to diagnose correctly the needs of every corporation. And even when they have such knowledge, regulators may also simply make mistakes. In the presence of such imperfections, firms may find

271. See Randall Morck, Andrei Shleifer \& Robert Vishny, Management Ownership and Market Valuation: An Empirical Analysis, 20 J. FIN. ECON. 293 (1988).

272. See id. at 311 (using the Tobin's Q measure of firm value).

273. See id.

274. See id.

275. From an overall efficiency standpoint, of course, this may not be so swell. Indeed, greater ownership concentration in the hands of management, while providing a partial solution to agency cost problems, also causes managers to hold a larger amount of undiversified risk than they would otherwise be inclined to hold. This enhanced risk is a true inefficiency, but perhaps one that is necessary in a second best world. 
themselves locked into legal protections that are systematically unresponsive to their needs.

To make matters worse, however, even where regulators possess adequate information and expertise, they are subject to influence on the part of the very parties they seek to regulate. Regulators that seek a job after they finish government service, for example, often find employment in the very industry they regulated. ${ }^{276}$ Regulators seeking an industry job may avoid imposing regulations that impose too high costs on their future employers. Other regulators may expand the breadth and complexity of regulations to justify increasing the size and scope of their regulatory agency. 277

In state corporate law, many have cited the above problems to argue that competition among the states provides a strong check on the ability of regulators to deviate from regulatory provisions that maximize share value. ${ }^{278}$ While we do not wish to enter this debate ourselves, ${ }^{279}$ it may at the very least make sense for regulators to consider allowing firms to optout of state corporate law prohibitions dealing specifically with selective payments to block shareholders.

The rationale for permitting firms to opt out of corporate governance rules is, in our estimation, relatively persuasive, at least insofar as these provisions deal predominantly with manager-shareholder relations. Entrepreneurs of firms, for example, at the time they initially sell securities to the public will have strong incentives to put in place both contractual as well as legal investor protection devices that investors find worthwhile. ${ }^{280}$

276. See, e.g., Gary S. Becker, A Theory of Competition Among Pressure Groups for Political Influence, 98 Q.J. ECON. 371 (1983); George J. Stigler, The Theory of Economic Regulation, 2 BELL J. ECON. 3 (1971).

277. See William A. Niskanen, JR., Bureaucracy and Representative Government $36-42(1971)$.

278. For a discussion of the race-to-the-top argument, see Daniel Fischel, The "Race to the Bottom" Revisited: Reflections on Recent Developments in Delaware's Corporation Law, 76 Nw. U. L. REV. 913, 919-20 (1982). See also Ralph K. Winter, Jr., State Law, Shareholder Protection, and the Theory of the Corporation, 6 J. LEGAL STUD. 251, 258 (1977) (making the argument that state corporate law competition results in a race to the top). For a discussion of the race-to-the-bottom hypothesis, see Lucian Arye Bebchuk, Federalism and the Corporation: The Desirable Limits on State Competition in Corporate Law, 105 HARv. L. REv. 1437 (1992). See also William L. Cary, Federalism and Corporate Law: Reflections upon Delaware, 83 YALE L.J. 663 (1974) (contending that state corporate law competition results in a race to the bottom).

279. One of us, nevertheless, has written on the topic. See Stephen J. Choi \& Andrew T. Guzman, Choice and Federal Intervention in Corporate Law, 87 VA. L. REV. 961 (2001); Stephen J. Choi \& Andrew T. Guzman, Portable Reciprocity: Rethinking the International Reach of Securities Regulation, 71 S. CAL. L. REv. 903 (1998).

280. See supra text accompanying notes $26-27$. 
To the extent rational and informed, investors then will increase their willingness to pay for the firm's shares, putting more money into the pocket of the entrepreneurs in control of the firm when it goes public.

Whether the practice of shareholder favoritism substantially benefits a particular firm, moreover, is often specific to that firm. For companies that start at the time of their IPO with significant block shareholders already present, the ability to make side payments could conceivably result in an increased overall level of private benefit appropriation. ${ }^{281}$ Such firms, therefore, may choose to keep prohibitions against selective payments in place. Other firms conducting an IPO, in contrast, may not have any large block shareholders aside from the share ownership of corporate insiders. In these situations, the ability to play favorites with shareholders may have the salubrious effects we have suggested. Similarly, the inefficiency cost of different forms of selective payments may also vary by firm. A firm, for example, may benefit greatly from the ability to employ a particular shareholder who has some particular expertise; banning selective payments to shareholders then may impose a disproportionately large cost on the firm. Consequently, giving individual firms the ability to determine their own selective payment policy may substantially increase overall corporate welfare.

While we are cautiously optimistic about the benefits of allowing optouts, we are also mindful of some of the potential pitfalls of such a regime. Most notably, entrepreneurs at the time of a firm's IPO may fail to select a patronage policy that maximizes overall corporate welfare due to constraints on information and expertise. Robert Daines and Michael Klausner, for example, argue in a study of antitakeover provisions present in corporate charter terms that firms often do not implement charter provisions that maximize firm value. ${ }^{282}$ The increase in firm value from an optimal selective payment policy, for example, may not exceed the cost to entrepreneurs of taking the time and resources to determine and implement such a policy. Regulators may be able to take some steps to mitigate such information and contracting costs, such as providing a "menu" of optional methods of selective payments that a firm may choose in its charter to permit. Regulators may also provide a checklist of the range of possible

281. See supra Part 1V.B.2. Recall, however, from our analysis there that even when management chooses to accommodate block shareholders, there may be strong reasons against appropriating too much value, since so doing would make a takeover extremely cheap, thereby allowing the block shareholder to force management out of the bargain entirely through an outright takeover.

282. See Robert Daines \& Michael Klausner, Do IPO Charters Maximize Firm Value? Antitakeover Protection in IPOs, 17 J. L. ECON. \& ORG. 83 (2001). 
wealth transfers allowable under each form of payment. Such mechanisms are often an effective, low cost means of disclosing the possibilities for effecting a selective payment policy within a firm. Having been made aware of the possibilities, investors may have an easier time evaluating and valuing the chosen policy of any particular firm.

Second, a liberal opt-out policy may fall prey to abusive practices, particularly if it allows opting out at any time. Once a firm is public and its shares are dispersed, for example, managers may then attempt to change its patronage regime in a self-serving way-a so-called "mid-stream" shift. ${ }^{283}$ One solution to the problem of mid-stream shifts is to allow firms to optout only at the time they initially sell securities to the public. While a standard objection to this solution is that it creates organizational inflexibility down the road, there are particularly strong reasons to prefer ex ante opt-outs in the context of shareholder favoritism. Once a firm decides to allow opportunistic payments, the benefit to shareholders comes from the ever-present threat imposed on managers that an outside investor will appear to extract rents from the managers. Allowing managers to prohibit selective payments at a later point in time, in turn, reduces the incentive of an outside investor ex ante to form a toehold, thereby reducing the threat on managers.

Third, firms considering whether to opt-out of various regulatory prohibitions against selective payments to shareholders may fail to take into account the interests of other stakeholders at the firm. When managers appropriate private benefits, for example, they may harm third parties. Customers, for example, may suffer a reduction in product quality if managers appropriate resources away from production, research, or quality control in order to line their own pockets. Nevertheless, many such stakeholders are themselves connected to the corporation through some contract form of relationship. As such, these parties may be in a position to demand better terms in their contractual dealings with the company, thereby causing the firm to internalize the cost of opportunism. ${ }^{284}$

283. See supra note 28.

284. Even where not connected through contract, moreover, third parties (such as surrounding communities) often receive little deference under state corporate and federal securities laws. For example, Meritt Fox has made the argument that labor has a strong interest in the accuracy of securities market prices. See Merritt B. Fox, Securities Disclosure in a Globalizing Market: Who Should Regulate Whom, 95 МiCH. L. REV. 2498, 2562-69 (1997). The SEC, nevertheless, has not made the protection of labor a factor in its decisionmaking. See Stephen J. Choi, Promoting Issuer Choice in Securities Regulation, 2 VA. J. INT'L L. 613, 628 n.56 (2001). Indeed, determining the precise impact on third parties often is extremely costly. Without a precise estimate on the impact to third parties, simply mentioning third parties as an additional interest which firms must take into account may 
Thus, while allowing some form of opt-out when it comes to shareholder favoritism is not without costs, such costs do not appear to be prohibitive. Moreover, providing an opt-out option does not force legislatures to engage in the complicated exercise of attempting to specify the precise preconditions under which shareholder favoritism would desirable or undesirable for each firm. To a large extent, firms making their opting decision before going public can be trusted ex ante to specify policies governing the manager-shareholder relationship that are reasonably responsive to their own idiosyncrasies.

\section{CONCLUSION}

Received wisdom within corporate law maintains that "favoritism" toward block shareholders has dangerous implications for overall corporate welfare. On first blush, the concerns raised by conventional wisdom have obvious merit: shareholder patronage frequently has the intent and the effect of co-opting the very individuals who are the most viable takeover threats toward incumbent management, causing them to fall short of their enormous potential as credible monitors of corporate welfare. When such individuals become the puppets of management, other shareholders and stakeholders stand to lose.

In this Article, we have questioned the overall persuasiveness of this received wisdom on at least two fronts. On a pragmatic level, we have argued that the regulatory apparatus used to scrutinize shareholder patronage has been more effective at relocating than eliminating the phenomenon. Because regulation is most able to deter the most patent and verifiable forms of favoritism, managers seeking to play favorites can (and do) find more indirect and more costly means for accomplishing the task, all to the detriment of the corporation as a whole.

On a more fundamental level, however, we have argued that even if eliminating patronage were practically feasible, the underlying arguments for doing so categorically seem far from compelling. Indeed, we have demonstrated how the ability to make bribes can, ironically, make managers worse off and all shareholders better off than in a world of

provide managers with a convenient pretext to engage in opportunism. The decision to take into account the interest of third parties, moreover, is one that affects not only this Article's proposal, but all corporate regulatory provisions that deal with managerial opportunism.

Similar arguments have been made against so-called shareholder constituency statutes. For a description of shareholder constituency statutes, see Stephen M. Bainbridge, Interpreting Nonshareholder Constituency Statutes, 19 PEPP. L. REV. 971 (1992); William J. Carney, Does Defining Constituencies Matter?, 59 U. CIN. L. REv. 385 (1990). 
effective prohibition. Indeed, when legal rules permit favoritism, managers are forced to choose between (i) sharing their private spoils with an opportunistic block shareholder attempting to extract a bribe, and (ii) reducing the amount of value they appropriate, deterring block ownership and enjoying it alone. As we have demonstrated, in many situations ${ }^{285}$ managers will prefer the deterrence option, a choice that redounds to the benefit of shareholders.

These conclusions place the extant legal prohibitions against many forms of selective payments to shareholders in a somewhat different (and more critical) light. At the very least, our analysis suggests a slightly different role for regulators than they have heretofore played. Rather than seeking to determine when an instance of favoritism is motivated by opportunism, courts and legislatures would more productively spend their time analyzing whether the preconditions exist for the beneficial effects we identify to take hold. On one end of the spectrum, managers of widely held firms operating under a potential threat from numerous rent-seeking outside investors will have strong incentives to make use of their own expertise to limit the amount of private benefits available to extract. On the other extreme, companies with preexisting block shareholders or those operating in dysfunctional or small takeover markets are less amenable to the permissive regime we have suggested. But be that as it may, the very heterogeneity of business characteristics renders questionable the "onesize-fits-all" form of regulation that has historically attached to managers who play favorites with shareholders. A first step in moving away from that existing regime would be to allow companies a limited ability to opt out of the regulatory status quo. In the pages above, we have suggested a number of modest ways to introduce this and other regulatory reforms.

Although our arguments have been limited to the manager-shareholder relationship and the market for corporate control, the fundamental point that having to share rents with others can act as a strong form of deterrence against opportunism is probably more general still. While not developed here, there are a number of other applications of this insight to corporate law, particularly insofar as other corporate stakeholders' claims are concerned. For example, our arguments might be redirected not to the takeover market, but rather to the corporate proxy system, in which $B$ represents a dissident shareholder who attempts to convince a block of other shareholders to side with $B$ and against management. In this case, the

285. See supra text accompanying notes 208-16 (enumerating the conditions under which patronage can be value-enhancing for other shareholders). 
supply curve from our analysis would represent the marginal cost of assembling political support for the dissident's alternate slate. Just as in the case of a block shareholder, management may wish to "buy off" dissidents who appear to pose a credible threat of displacing management.

Other applications of our theory might even transcend the shareholdermanager relationship. For instance, while creditors usually enjoy a relatively fixed return on their investment, the default risk that the firm presents can inject greater uncertainty into this claim. (A similar point applies to other fixed claimants, including labor, suppliers, and customers). Such fixed claimants may, at some expense, investigate the firm to determine the current risk of insolvency. Managers of companies near default may then attempt to favor a particular pivotal creditor of the firm (that has uncovered the firm's impending insolvency), allowing the manager to stay in control while fending off or delaying bankruptcy. Arguably fearing the opportunistic dangers for other creditors that this incentive creates, federal law vests bankruptcy trustees with the power to void preferences given to a creditor close to the filing of bankruptcy. ${ }^{286}$ Our analysis presents a potential cost of such prohibitions. Indeed, if the terms of the agreement with the pivotal creditor force management to surrender a substantial value of its private benefits (from delaying bankruptcy), permitting such favoritism may give management an incentive to take actions that avoid financial distress altogether. Not only does such restraint help debt holders, but maintaining a strong equity cushion may also be in the interests of overall corporate welfare. While such extensions are interesting, we leave them for future endeavors.

286. See generally David B. Young, Preferences and Fraudulent Transfers, in PRACTISING LAW INSTITUTE, 23RD ANNuAl CURRENT DEVElopmENTS IN BANKRUPTCY AND REORGANIZATION 881 (2001) (providing a summary of voidable preference doctrine inside the United States). See also Vern Countryman, The Concept of Voidable Preference in Bankruptcy, 38 VAND. L. REV. 713 (1985) (tracing the history of prohibitions against preferential transfers near bankruptcy).

Under Seetion 547 of the Bankruptcy Code, the trustee in bankruptcy may void transfers made to a shareholder within 90 days of the filing of a bankruptcy petition. See 11 U.S.C. $\S 547(\mathrm{~b})(4)(A)$ (2000). The trustee may void preferences given to insiders up to a year prior to the filing of a petition for bankruptcy. See 11 U.S.C. $\$ 547(b)(4)(B)$. Although a variety of exceptions exists, including the contribution on the part of a creditor of "new value" in return for the preference, none of the exceptions apply to preferences given on the part of managers to delay opportunistically the filing of a bankruptcy petition. See 11 U.S.C. $\$ 547$ (c)(1)(A) (setting forth the new value exception). 